\title{
Biocatalysis as Useful Tool in Asymmetric Synthesis: An Assessment of Recently Granted Patents (2014-2019)
}

\author{
Pablo Domínguez de María ${ }^{1, *}$, Gonzalo de Gonzalo ${ }^{2, *(\mathbb{D})}$ and Andrés R. Alcántara ${ }^{3, *(D)}$ \\ 1 Sustainable Momentum, SL. Av. Ansite 3, 4-6, E-35011 Las Palmas Gran Canaria, Spain \\ 2 Organic Chemistry Departament, University of Sevilla, c/ Profesor García González 2, 41012 Sevilla, Spain \\ 3 Department of Chemistry in Pharmaceutical Sciences, Section of Organic Chemistry (Pharmaceutical \\ Chemistry), Faculty of Pharmacy, Complutense University of Madrid, Plaza de Ramón y Cajal, s/n., \\ E-28040 Madrid, Spain \\ * Correspondence: dominguez@sustainable-momentum.net (P.D.d.M.); gdegonzalo@us.es (G.d.G.); \\ andalcan@ucm.es (A.R.A.); Tel.: +34-60-956-52-37 (P.D.d.M.); +34-95-455-99-97 (G.d.G.); \\ +34-91-394-18-20 (A.R.A.)
}

Received: 6 September 2019; Accepted: 22 September 2019; Published: 25 September 2019

\begin{abstract}
The broad interdisciplinary nature of biocatalysis fosters innovation, as different technical fields are interconnected and synergized. A way to depict that innovation is by conducting a survey on patent activities. This paper analyses the intellectual property activities of the last five years (2014-2019) with a specific focus on biocatalysis applied to asymmetric synthesis. Furthermore, to reflect the inventive and innovative steps, only patents that were granted during that period are considered. Patent searches using several keywords (e.g., enzyme names) have been conducted by using several patent engine servers (e.g., Espacenet, SciFinder, Google Patents), with focus on granted patents during the period 2014-2019. Around 200 granted patents have been identified, covering all enzyme types. The inventive pattern focuses on the protection of novel protein sequences, as well as on new substrates. In some other cases, combined processes, multi-step enzymatic reactions, as well as process conditions are the innovative basis. Both industries and academic groups are active in patenting. As a conclusion of this survey, we can assert that biocatalysis is increasingly recognized as a useful tool for asymmetric synthesis and being considered as an innovative option to build IP and protect synthetic routes.
\end{abstract}

Keywords: biocatalysis; asymmetric synthesis; patents; lipases; oxidoreductases; lyases; transaminases

\section{Motivation. The Role of Granted Patents as Key Actors in Innovation}

Biocatalysis is currently recognized as a mature technology for asymmetric synthesis, based on the excellent selectivity (enantio-, chemo, and regio-) that enzymes often display in many chemical processes. The field has experienced a tremendous development when emerging Molecular Biology techniques, used to produce and design enzymes, have been synergized with both process-development concepts (batch to continuous reactors) and medium engineering strategies (non-aqueous media, immobilization, etc.). As a result, biocatalysis can fulfil, in many cases, the demands of modern organic synthesis, which must align a high selectivity and efficiency with sustainability and tight economic figures. As a result, an increasing number of industrial processes have been successfully established, comprising many diverse examples using free enzymes, whole cells, systems biocatalysis, multi-step processes, etc. [1-19].

The abovementioned broad interdisciplinarity profile makes biocatalysis in a fertile landscape for innovation. It is common that researchers of different backgrounds (chemistry, biology, engineering, etc.) 
cooperate closely in setting up new enzymatic reactors [20-23]. Overall, each biocatalytic industrial reaction contains highly evolved parts, which are not standing alone, but that do form a robust process when all of them are combined smartly. Some key concepts for industrial biocatalysis may be: i) designed enzyme variants with improved selectivity, high resistance to chemicals, thermostability, etc. [24-30]; ii) bio-based (non-conventional) solvents used as co-solvents in water, or as biphasic systems [31-38]; neoteric solvents, such as deep eutectic solvents (DES) [39-44]; iii) whole-cells [45-48], immobilization [49-56], continuous processes, etc. [12,23,57,58]; and iv) metrics [59-62], high productivities to assure an industrially-sound reaction.

To obtain deeper insights into these expected innovations, this paper discloses a patent survey related to biocatalysis applied to asymmetric synthesis. Although this genre of studies is (surprisingly) rather scarce in the open literature $[8,63,64]$, we believe that the approach may nicely reflect the modern trends in the field, provided by academic and industrial groups, and comprising different enzymes and chemical processes. Importantly, to further refine the innovation assessment, the focus of the study is put solely on those patents that have been granted over the last five years (2014-June 2019). Remarkably, granted patents may provide further proofs on the necessary steps of novelty, innovation, and resolution of industrial problems, as demanded for intellectual property (IP) rights. To simplify the reading of the article, the granted patents are discussed by enzyme types, covering several relevant case studies. Moreover, the focus of the article is strictly scientific, and no information regarding the countries in which the invention is granted, nor whether or not patent fees are being satisfied, is provided. It must be noted, however, that readers can easily retrieve that information from the patent servers, by simply tracking the patent number provided in the references. To follow a consistency with publication rules, the years denoted in the references are the publication years; in all cases, the effective dates of those granted patents mentioned in this article are included between 2014-2019, and it can be retrieved from patent servers as well. According to the survey, around 200 patents related to biocatalysis have been successfully granted within the last five years, as shown in Figure 1.

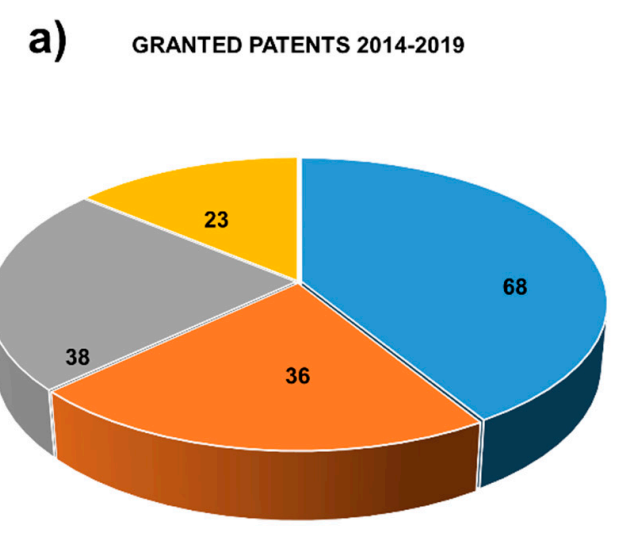

- HYDROLASES " REDOX " TRANSAMINASES - LYASES

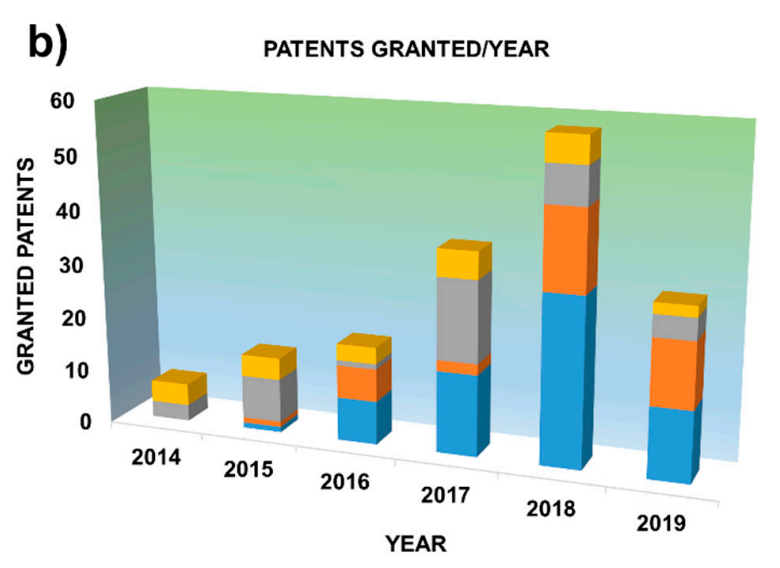

$\because$ HYDROLASES $\square$ REDOX $\backsim$ TRANSAMINASES $\backsim$ LYASES

Figure 1. Patents granted in 2014-2019 employing the most usual types of enzymes, according to several patent engine servers (e.g., Espacenet, SciFinder, Google Patents).

Notably, examples for all enzyme types have been found, for asymmetric synthesis purposes, and the main strategies to achieve patentability are either the protection of known enzymes and variants with different sequences (covering up to some homology), or the use of novel substrates for the intended reactions, or a combination of both approaches. Apart from industrial activities pharmaceutical and fine chemistry firms - several academic groups have proven to be active in IP activities as well. 


\section{Granted Patents Related to Hydrolases in Asymmetric Synthesis}

\subsection{Lipases}

Hydrolases (Enzyme Commission number EC 3,) undeniably represent the most valuable type of enzymes in applied biocatalysis, due to their unique properties, such as broad substrate specificity, commercial availability, lack of need to use any cofactor, and high capability to work at high substrate concentrations [65-73]. Inside this group of enzymes, lipases (EC 3.1.1.3) can be considered the most useful, according to the ample number of processes in which they have been employed at lab [74-77] and industrial scale [78-82], mainly because they can perform with notable precision (chemo-, regio- and/or stereoselectivity) not only in their natural environment (aqueous solutions) but also in non-conventional media $[66,75,79,82-85]$, therefore being catalogued as natural promiscuous enzymes [86]. Although the main industrial uses of lipases are in the detergent and food and beverage areas, there are plenty of examples in which these enzymes are employed in asymmetric synthesis [63]; in this sense, examples taken from granted patents in the last five years are hereunder presented.

\subsubsection{Stereoselective Hydrolysis Catalyzed by Lipases}

Thus, regarding the employ of lipases in the preparation of chiral building blocks for the synthesis of active pharmaceutical ingredients (APIs), some recent patents describe different stereoselective hydrolytic procedures taking advantage of the enzymatic capability of discriminating between enantiomers. For instance, a patent from Zhejiang Changming Pharmaceutical Co., Ltd., [87], granted in 2018, describes the preparation of the anti-epileptic drug levetiracetam (Keppra ${ }^{\circledR}$, Elepsia ${ }^{\circledR}$ ) starting from racemic methyl 2-bromo(chloro)butanoate, using Novozym 435, a commercially available preparation of lipase B from Candida antarctica immobilized on Lewatit VP OC 1600, a macroporous acrylic polymer resin [88]. The key step, a kinetic resolution of a racemic 2-haloester 1, leads to the $(S)$-acid and the desired ester $(R)-\mathbf{2}$, which is extracted using ethyl acetate and converted into levetiracetam via transformation of the (R)-ester into the $\alpha$-aminoamide $(S)-3$ and a further cyclization with 4-chlorobutanoyl chloride, as shown in Scheme 1.

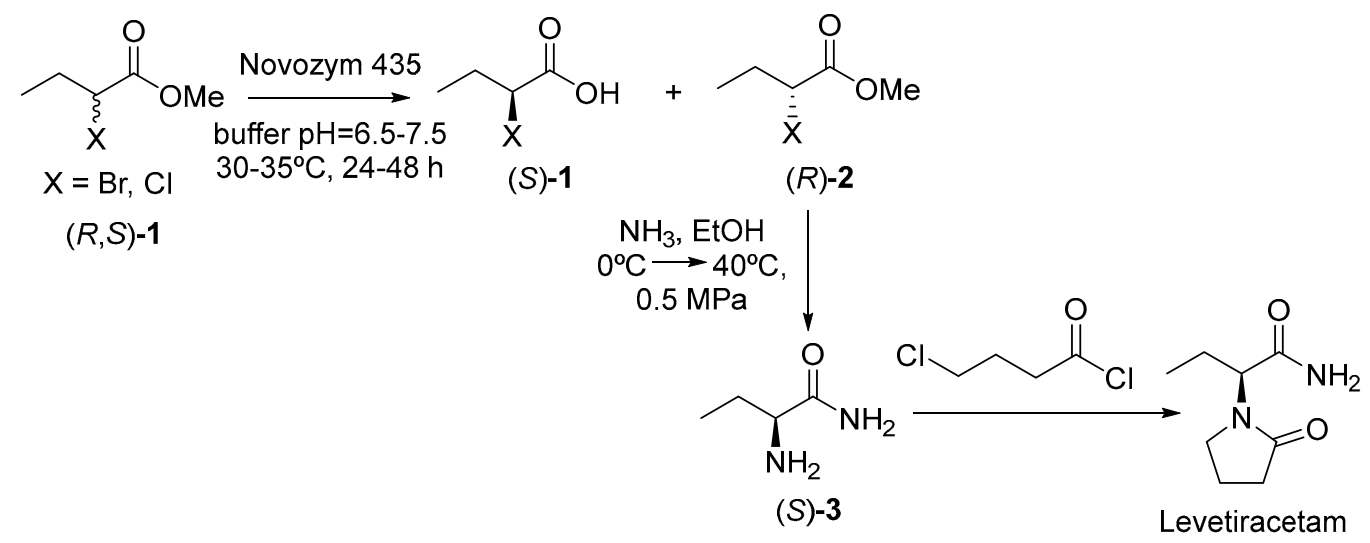

Scheme 1. Chemoenzymatic preparation of levetiracetam starting from a racemic 2-haloester.

In another example, developed by Daiichi Sankyo Co. Ltd., and granted in 2019 [89], the kinetic resolution of $(R, S)-1-(((1,1,1,3,3,3$-hexafluoropropan-2-yl)oxy)carbonyl)oxy)ethyl isobutyrate $((R, S)-4)$ was carried out by a lipase-catalyzed hydrolysis in a buffer/organic solvent biphasic system to discard the corresponding alcohol (S)-5 from the desired ester (R)-4 (Scheme 2).

In order to catalyze this enzymatic hydrolysis, different commercial lipases (from $C$. antarctica, Candida rugosa and Thermomyces lanuginosus), organic cosolvents (acetonitrile, ethers, saturated and aromatic hydrocarbons, alcohols) and reaction conditions (temperature from $0{ }^{\circ} \mathrm{C}$ to $80^{\circ} \mathrm{C}$, reaction times ranging from $1 \mathrm{~h}$ to $120 \mathrm{~h}$ ) were tested; the best results were obtained with Chirazyme L2, $\mathrm{C} 4$ (a commercial preparation of $C$. antarctica lipase similar to Novozym 435) and buffer $\mathrm{pH}=7 / \mathrm{MTBE}$ 
$(5 / 1, V / V)$ at $20{ }^{\circ} \mathrm{C}$, with reported conversions of around $40 \%$ and ee values higher than $99 \%$. Subsequently, $(R)-4$ was used to furnish a carbamate 7 upon reaction with the enantiopure amide 6 (as a sulphonic salt). This carbamate 7 is a promising prodrug useful as inhibitor of carboxypeptidase $\mathrm{U}$ (also known as activated thrombin-activatable fibrinolysis inhibitor, TAFIa), for treating thromboembolic disorders [90-92].<smiles>Cc1ccc(S(=O)(=O)O)cc1</smiles>

Scheme 2. Synthesis of prodrug 7 possessing TAFIa inhibitory activity.

Another enzymatic hydrolysis useful for synthesizing drug precursors was patented by Beijing University of Chemical Technology [93] and granted in 2017; the stereoselective hydrolysis of a racemic mixture of $\mathrm{N}$-protected cis-4-amino-cyclopent-2-en-1-ol (cis-8, $20 \mathrm{~g} / \mathrm{L}$, Scheme 3) was carried out using lipase $\mathrm{B}$ from $\mathrm{C}$. antarctica at $\mathrm{pH}=5$ and $60^{\circ} \mathrm{C}$ in $4 \mathrm{~h}$, to furnish the desired alcohol $(1 S, 4 R)-9$ (conversion $45 \%$, ee $99 \%$ ). This enantiopure alcohol is a building block for the preparation of ticagrelor (Brilinta ${ }^{\circledR}$, Brilique ${ }^{\circledR}$, Possia ${ }^{\circledR}$ ) a platelet aggregation inhibitor originally produced by AstraZeneca $[94,95]$.

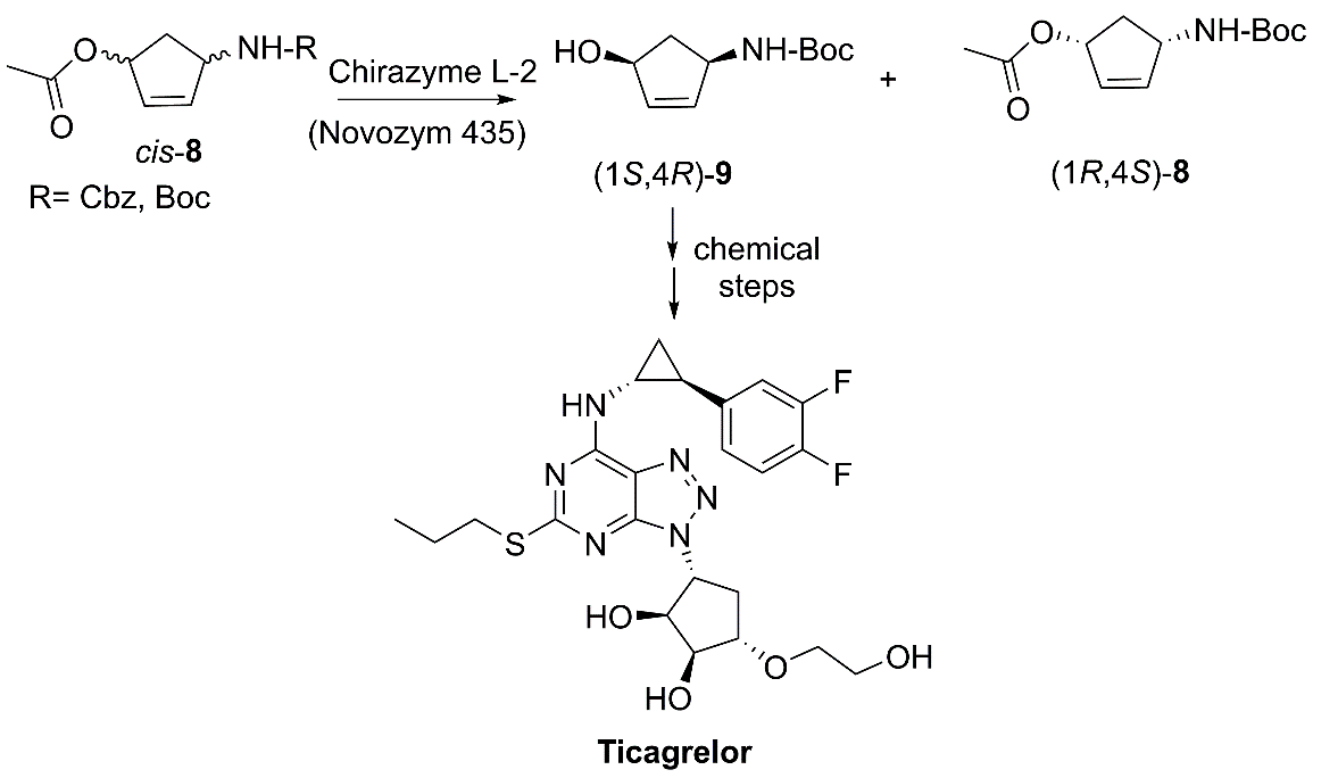

Scheme 3. Synthesis of an enantiopure precursor of ticagrelor. 
A very interesting process, patented by and recently granted in 2019 to AbbVie Inc. describes preparation of an intermediate $((1 R, 2 R)-\mathbf{1 2}$, Scheme 4$)$ in the synthesis of viral protease inhibitors [96]. In this case, a double enzymatic procedure is followed starting from ( \pm )-dipropyl 2-(difluoromethyl)cyclopropane-1,1-dicarboxylate ( \pm )-10, and employing primarily a lipase (from T. lanuginosus or Rhizomucor miehei) in a biphasic medium (phosphate buffer with 10\% DMF, $30{ }^{\circ} \mathrm{C}, 95 \mathrm{~h}$ ) to separate the undesired monoacid $(1 R, 2 S)-\mathbf{1 1}$ (extracted from the reaction media using MTBE) from the chiral diester (R)-10 (64.4\% yield, 97.4\% ee). In a second step, an esterase from Bacillus subtilis cloned and expressed in cells from Escherichia coli was employed for the desymmetrization of the stereocentre at $\mathrm{C} 1$ of $(R)-\mathbf{1 0}$ to yield $(1 S, 2 R)-\mathbf{1 0}(84.2 \%$ yield, $99.4 \%$ ee) in an aqueous solution at $30^{\circ} \mathrm{C}$ in $68 \mathrm{~h}$.

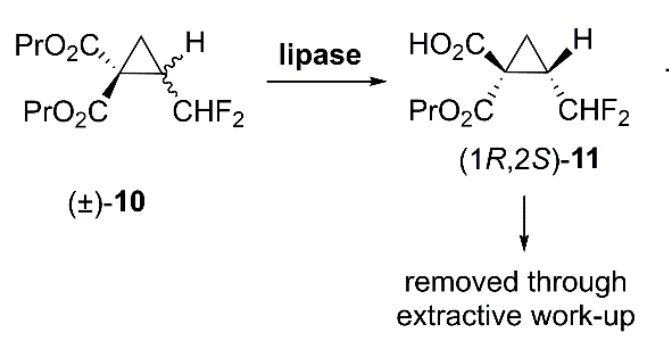

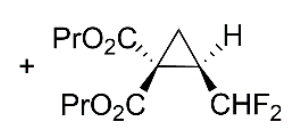

$(R)-10$

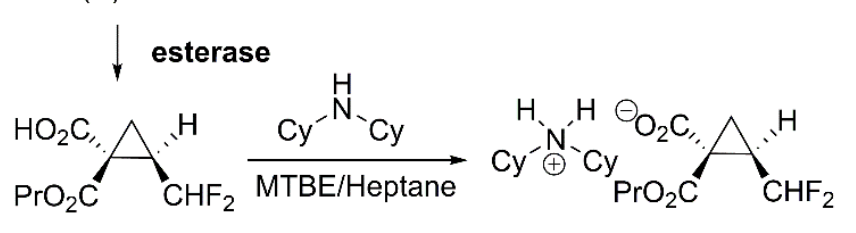

$(1 S, 2 R)-10$
$(1 S, 2 R)-11$

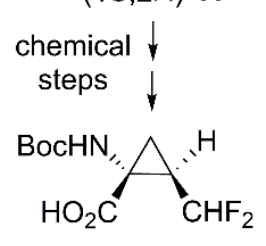

$(1 R, 2 R)-12$

Scheme 4. Chemoenzymatic synthesis of an enantiopure precursor of a viral protease inhibitor.

All the patents mentioned up to this point share the common feature of placing the enzymatic asymmetric hydrolysis in an initial stage of the synthetic scheme leading to the desired API. More infrequently, the enzymatic biotransformation is applied once the structure of the API is almost complete. For instance, a patent from Tiantai Yisheng Biochemical Technology Co., Ltd., (granted in 2019) describes the enantioselective hydrolysis of racemic esters of valsartan (Diovan ${ }^{\circledR}$, an angiotensin II receptor blocker (ARBs or sartans), a drug which modulates the renin-angiotensin system, used in the treatment of hypertension, diabetic nephropathy and congestive heart failure [97]) catalyzed by lipases [98], as depicted in Scheme 5.<smiles>[R]OC(=O)[C@H](C(C)C)N(Cc1ccc(-c2ccccc2-c2nn[nH]n2)cc1)C(=O)CCCC</smiles>

$(R, S)-13$<smiles>[R]OC(=O)C(C(C)C)N(Cc1ccc(-c2ccccc2-c2nn[nH]n2)cc1)C(=O)CCCC</smiles>

$(R)-13$<smiles>CCCCC(=O)N(Cc1ccc(-c2ccccc2-c2nn[nH]n2)cc1)[C@@H](C(=O)O)C(C)C</smiles>

Valsartan

Scheme 5. Enzymatic resolution of racemic esters of valsartan.

Thus, different commercial immobilized lipases (Lipozyme TL IM (T. lanuginosus), Lipozyme RM IM (R. miehei), Novozym 435 (lipase B from C. antarctica) from Novozymes; lipases PS IM (Burkholderia 
cepacia), Lipase AK (Pseudomonas fluorescens) and Lipase AS (Aspergillus niger), from Amano) were used for the hydrolysis of racemic esters $((R, S)-13, R=$ ethyl, methyl or isopropyl) in a buffer solution ( $\mathrm{pH}$ varying between 4.0-9.0) with different amounts of organic cosolvents (acetone, isopropanol or ethyl acetate), rendering the desired valsartan $((S)$ absolute configuration) in good yields (up to $90-95 \%$ after work-up) and enantiopurity (up to $99.5 \%$ ).

\subsubsection{Regio- and Chemoselective Hydrolysis Catalyzed by Lipases}

Lipases can be also used for the regioselective hydrolysis of a specific ester group without altering another similar functional groups placed in another part of the molecule, under very mild reaction conditions. In a recent patent from Harbin University of Commerce, granted in 2019 [99], a lipase (from Candida $\mathrm{sp}$. among others) catalyzing the monohydrolysis of nifedipine (dimethyl 2,6-dimethyl-4-(2-nitrophenyl)-1,4-dihydropyridine-3,5-dicarboxylate (Scheme 6), a calcium channel blocker [100]) is reported to furnish the corresponding monoacid 14; this reaction is carried out in a mixed system of aq. soln./org. solvent (such as isooctane, hexane, cyclohexane or toluene), and reacting under stirring at $30-40{ }^{\circ} \mathrm{C}$ for $3-5$ days. The monoacid ( $23 \%$ yield, no ee reported) is the key step for synthesizing other 1,4-dihydropyridine structures possessing two different alkoxycarbonyl groups in positions 3 and 5 (such as aranidipine, azeldinipide, barnidipine, etc.), which are more selective and efficient drugs [101].<smiles>COC(=O)C1=C(C)NC(C)=C(C(C)C)C1c1ccccc1N(C)OC(C)C</smiles>

Scheme 6. Enzymatic mono-hydrolysis of nifedipine.

The possibility of performing chemoselective reactions is another attractive property of lipases. In this sense, a patent from AstaTech Chengdu Biopharmaceutical Co., Ltd. granted in 2018 [102], reports the use of several lipases (Novozym 435 and lipase from pig pancreas leading to the best results) and esterases for the hydrolysis of different alkyl esters of $N$-Boc-(1R,3S,4S)-2-azabicyclo[2.2.1] heptane-3-carboxylate (16, Scheme 7), to yield acid 17 without removing the carbamate protecting group. In this process, essential for the preparation of ledispavir (Harvoni ${ }^{\circledR}$, Gilead, in combination with sofosbuvir (see Scheme 14) for treatment of hepatitis C [103], the enzymatic hydrolysis allows the preparation of $\mathbf{1 7}$ in good yields (up to $77 \%$ ) and high d.e. values (up to $99.7 \%$ ), therefore avoiding the main problem of the chemical basic hydrolysis ( $\mathrm{LiOH}$ in $\mathrm{THF} / \mathrm{H}_{2} \mathrm{O}$ ), a partial racemization of the stereogenic center at $\mathrm{C} \alpha$ of the alkoxycarbonyl group.

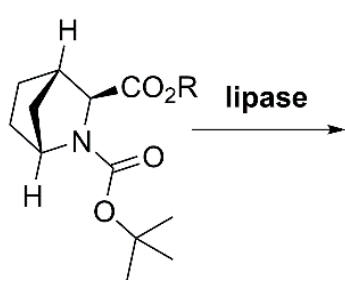

16

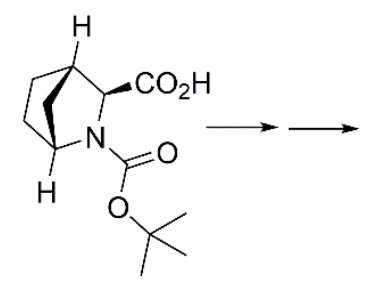

17

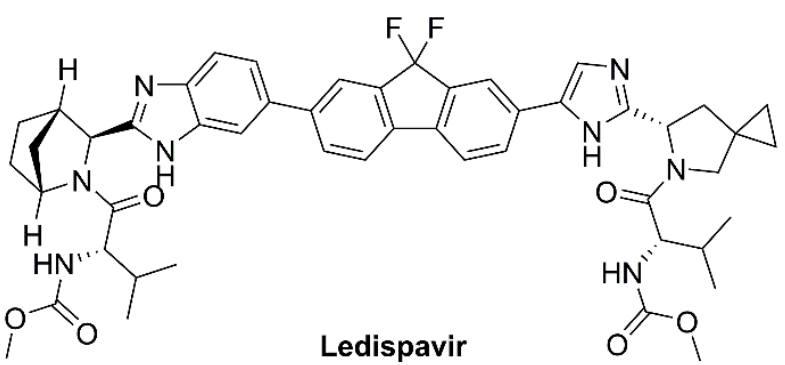

Ledispavir

Scheme 7. Enzymatic preparation of a ledispavir intermediate. 


\subsubsection{Stereoselective Acyl-Transfer Catalyzed by Lipases}

As stated above [66,75,79,82-85], lipases are perfectly capable of working in non-aqueous reaction media, therefore catalyzing acyl transfer processes (esterifications, transesterifications, amidations, etc) with excellent precision. Hence, in a patent from Ningbo Xinkai Biotechnology Co., Ltd., granted in 2017 [104], the use of Nozozym 435 for the stereoselective monoacylation of prochiral 2-(2-(2,4-difluorophenyl)allyl)propane-1,3-diol 18 (Scheme 8) with isopropanoic anhydride in a mixture of $\mathrm{NaHCO}_{3} /$ toluene at $15{ }^{\circ} \mathrm{C}$ during $24 \mathrm{~h}$ is reported to furnish monoester 19 (75\% yield, ee not reported), a chiral building block for the preparation of antifungic posaconazole (Noxafil ${ }^{\circledR}$, Posanol $^{\circledR}$ ). This biocatalytic monoacylation is not the real innovation of the patent, because it was described previously for this same enzyme using vinyl acetate in acetonitrile [105]; in this case, the synthesis of starting diol 18 is claimed to improve the previously reported procedures [106-108].<smiles>C=C(C[C@@H](CO)COC(=O)C(C)C)c1ccc(F)cc1F</smiles>

Scheme 8. Chemoenzymatic preparation of an intermediate in the synthesis of posaconazole.

The use of biotransformations in the synthesis of statins, inhibitors of 3-hydroxy-3-methylglutaryl coenzyme A (HMG-CoA) reductase, widely prescribed for the pharmacological treatment of hypercholesterolemia and dyslipidaemia, has been recently reviewed $[109,110]$ In this context, we will comment some recently granted patents using different enzymes.

For instance, Shandong Qidu Pharmaceutical Co., Ltd. patented a transesterification protocol, granted in 2016 [111] and schematized in Scheme 9 for the preparation of pitavastatin (Livalo ${ }^{\circledR}$, Livazo ${ }^{\circledR}$, among others trade names), a member of the superstatin family [109]. 


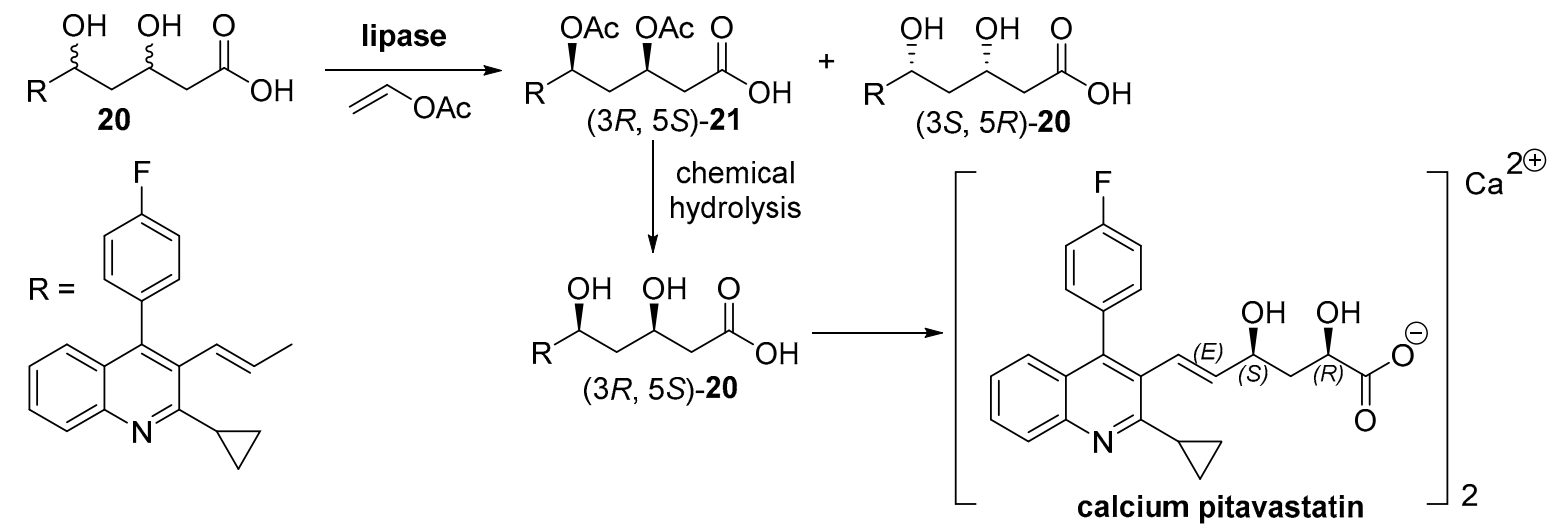

Scheme 9. Preparation of Pitavastatin through an enzymatic transesterification.

In this process, the biocatalyst (commercial lipases from different origins, the best results being obtained with lipase from B. cepacia) is able to discriminate between the stereoisomers of starting diol $\mathbf{2 0}$ (it is not specified in the patent if $\mathbf{2 0}$ is a mixture of the four possible stereoisomers, although according to the reported results it must be a racemic mixture of syn enantiomers). The acylation is carried out in a biphasic medium phosphate buffer/organic solvent (dichloromethane, ethyl acetate, tetrahydrofuran, methyl tert-butyl ether, cyclohexane, toluene or xylene) in different ratios (from $\frac{1}{2}$ to $1 / 5, \mathrm{~V} / \mathrm{V}$ ) at temperatures ranging from 0 to $40^{\circ} \mathrm{C}$, and different reaction times (up to $72 \mathrm{~h}$ ). Reaction yields varied between 43.1 and $47.3 \%$, with excellent enantiopurity of the diacetate (3R, 5S)-21 (97-99\%), which is separated (by ethanol precipitation) from the non-converted diol (3S, 5R)-20, and subsequently hydrolyzed chemically $(\mathrm{EtOH} / \mathrm{NaOH})$ and stirred with a $\mathrm{CaCl}_{2}$ solution to finally furnish the calcium salt of pitavastatin.

Treprostinil (Remodulin ${ }^{\circledR}$, Orenitram ${ }^{\circledR}$, Tyvaso ${ }^{\circledR}$, Scheme 10), a synthetic analog of prostacyclin (PGI2), is a vasodilator used for the treatment of pulmonary arterial hypertension [112], of which synthesis is complex and time consuming [113]. In a patent from Everlight Chemical Industrial Corporation granted in 2016, a stereo- and regioselective acylation of diol $\mathbf{2 1}$ with vinyl acetate, performed in $n$-hexane at $22{ }^{\circ} \mathrm{C}$ with lipase $\mathrm{AK}$ from Amano, leads to the regioselective acylation of the hydroxyl group in the cyclic moiety of $\mathbf{2 1}$ without acylating the one on the exocyclic chain, and leading to the desired stereochemistry of 22 (no yields or ee reported).<smiles>[R20]c1cccc2c1C[C@H]1C[C@H](O)[C@@H](CCC(O)C(C)C)[C@H]1C2</smiles>

$\mathrm{R}=\mathrm{C} 1-6$ alkyl group

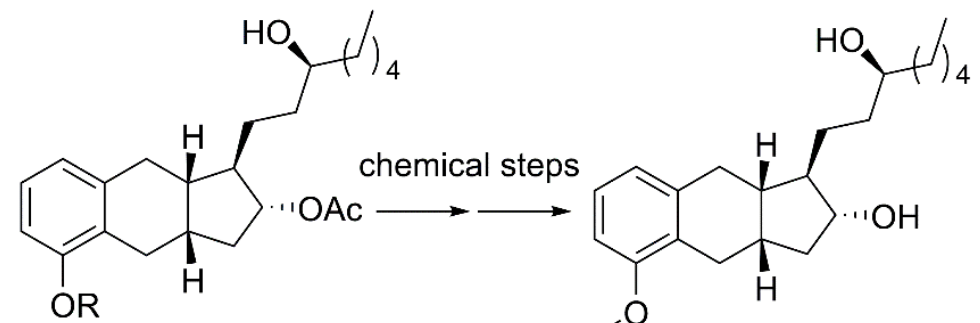

22
Treprostinil

Scheme 10. Preparation of treprostinil through an enzymatic acylation.

In another patent from Wuxi Fortune Pharmaceutical Co., Ltd., granted in 2018 [114], the gram-scale kinetic resolution (Scheme 11) of racemic hidroxynitrile $(R, S)$-24, obtained from racemic epyclorhydrine $(R, S)-\mathbf{2 3}$, was reported using an enzymatic transesterification with perchlorophenyl acetate and lipase $\mathrm{B}$ from $C$. antarctica, supported on an acid resin (Novozym 435?), to obtain acetate $(R)-25$, which hydrolysis leads to L-carnitine, an essential co-factor in the metabolism of lipids involved in the generation of cellular energy $[115,116]$. 


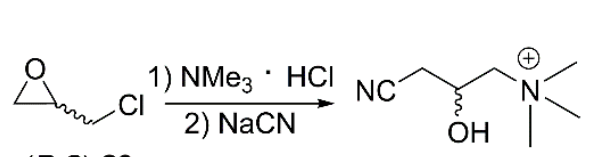

$(R, S)-23$
$(R, S)-24$

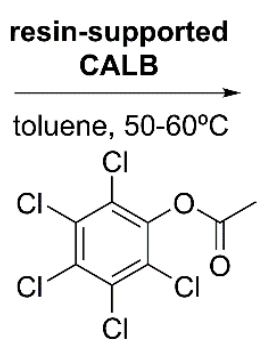<smiles>C[N+](C)(C)C[C@H](O)CC#N</smiles><smiles>C[N+](C)(C)C[C@H](O)CC(=O)O</smiles>

\section{L-carnitine}

Scheme 11. Chemoenzymatic preparation of L-carnitine.

The resolution of chiral amines is a very attractive research area, because of the plethora of applications described for such enantiopure compounds [117,118], which can be obtained by using oxidoreductases [119] (see Section 3.2), transaminases [120] (Section 4), and lipases [121,122], as we will comment here. In fact, different companies have been actively working in this area during the last years. For instance, in patent granted in 2018 [123], a methodology for preparing enantiopure (R)-1,2,3,4-tetrahydronaphthalen-2-amine (2-aminotetralin, 2-AT, $(R)-27$, Scheme 12a), a rigid analogue of phenylisobutylamine capable to inhibit the reuptake of serotonin and norepinephrine [124] was reported. In this case, the reaction was carried out in a $2 \mathrm{~L}$ autoclave filled with $1 \mathrm{~L}$ of toluene, $117.6 \mathrm{~g}$ of $(R, S)$-27 (obtained via reductive amination of starting ketone 26$), 172 \mathrm{~g}$ of $(R)$-O-acetyl mandelic acid, commercial Novozym 435 and $\mathrm{H}_{2}$ /nickel catalyst (KT-02) to transform the kinetic resolution into a dynamic kinetic resolution by racemizing the unreacted (S)-27. After $24 \mathrm{~h}, 144.2 \mathrm{~g}$ of $(R)-28$ (95\% yield, $99 \%$ ee) were isolated and subsequently hydrolyzed to finally yield $(R)-28$ with excellent yield $(92 \%)$ and enantiopurity (99\%).

a)

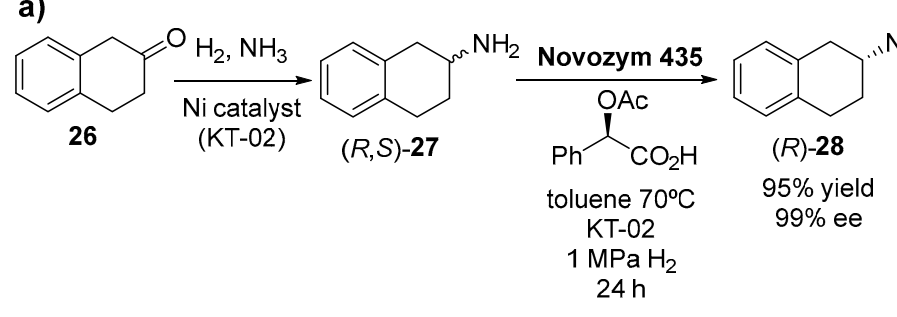

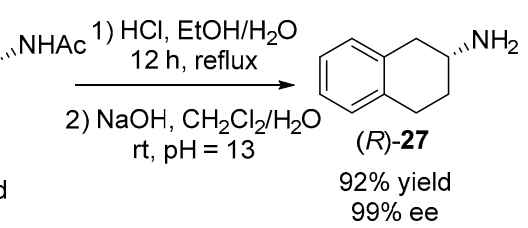<smiles>C#CCNC1CCc2ccc(Cl)cc21</smiles>

$(R)-29 \quad$ Rasagline $99.7 \%$ ee

1) $\mathrm{HCl}, \mathrm{EtOH} / \mathrm{H}_{2} \mathrm{O}$ 2) $\mathrm{NaOH}, \mathrm{CH}_{2} \mathrm{Cl}_{2} / \mathrm{H}_{2} \mathrm{O}$ rt, $\mathrm{pH}=13$ $(R)-30$ $96 \%$ yield
$99 \%$ ee toluene $50^{\circ} \mathrm{C}-02$
KT $1 \mathrm{MPaH}_{2}$ $18 \mathrm{~h}$

c)

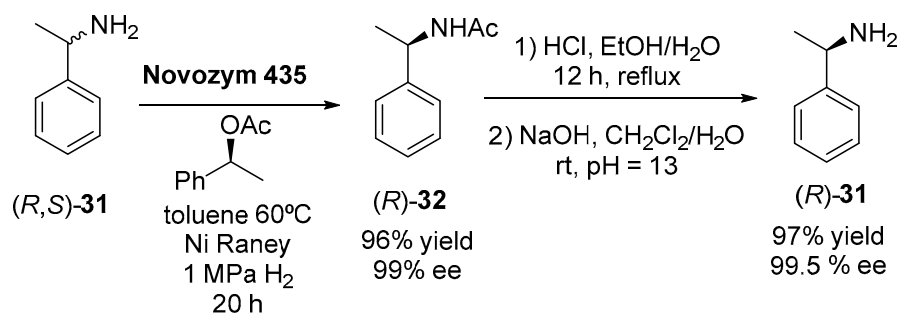

Scheme 12. Lipase-catalyzed preparation of enantiopure amines. 
In another very similar example shown in Scheme 12b, the dynamic kinetic resolution of $(R, S)-29$ was reported in a patent [125] granted in 2018 for the preparation of an enantiopure intermediate in the synthesis of rasagline (Azilect ${ }^{\circledR}$ ), an irreversible inhibitor of monoamine oxidase- $\mathrm{B}$, used as a single therapy in the symptomatic treatment in early stages of Parkinson's disease or as an additional therapy in more severe cases $[126,127]$. In this case, the lipase used is different, but the final results $(0.5 \mathrm{~L}$ reaction volume) are also excellent in terms of both yield and enantiopurity. Finally, the preparation of optically pure $(R)-1$-phenylethan-1-amine $((R)-31$, Scheme $12 \mathrm{c})$ is described following a similar methodology in another patent [128] granted in 2017.

\subsubsection{Site-selective Acyl-Transfer Catalyzed by Lipases}

The lipase capability for catalyzing site-selective acylations/deacylations has been also exploited in recently granted patents. For instance, a HC-Pharma AG patent granted in 2018 [129] describes the mono-deacetylation of 33 (Scheme 13), a precursor in the preparation of sofosbuvir (Sovaldi ${ }^{\circledR}$, Gilead), a direct acting antiviral medication used as part of combination therapy to treat chronic hepatitis C [130].

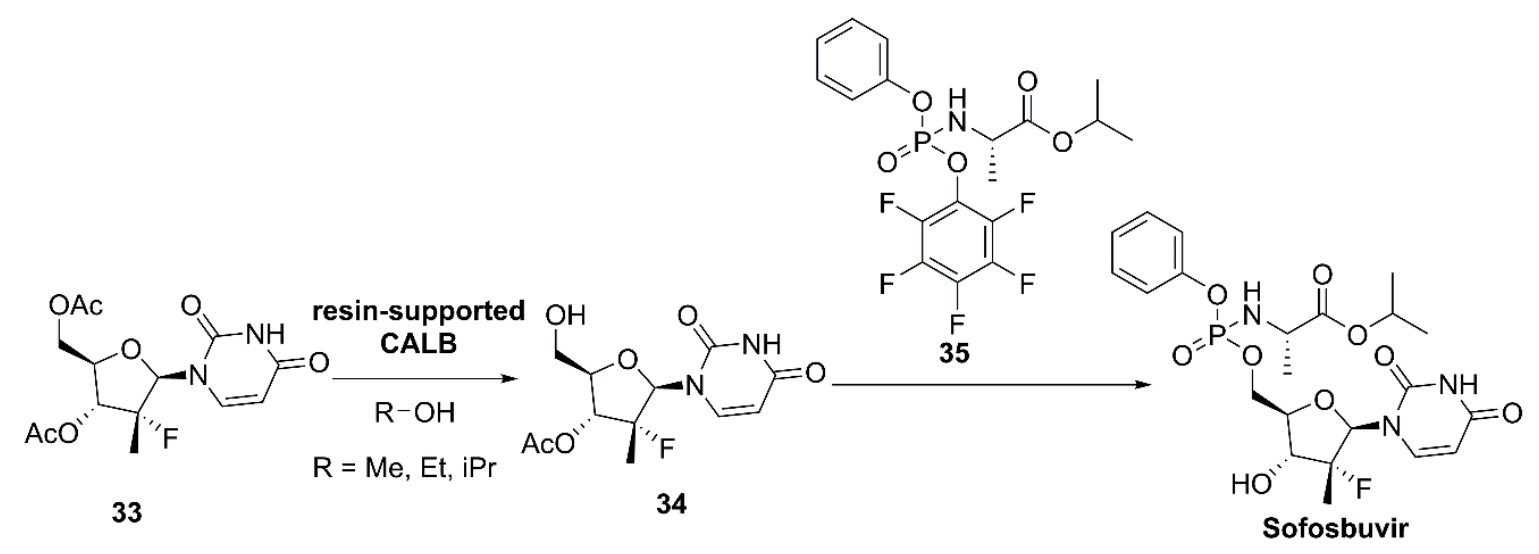

Scheme 13. Chemoenzymatic synthesis of sofosbuvir.

The deacetylation is carried out using $500 \mathrm{~g}$ of 33 in $5 \mathrm{~L}$ of an alcoholic medium (isopropanol, methoxypropanol or ethanol/water) via a single transesterification at $60^{\circ}$ during $48 \mathrm{~h}$ of the acetoxy group at position $5^{\prime}$ using $100 \mathrm{~g}$ of a resin-supported lipase B from C. antarctica (Novozym 435?) as the catalyst, leading to quantitative yields (between 99.2 and 99.6\%) after a simple purification procedure (cooling to $25{ }^{\circ} \mathrm{C}$, filtering out the lipase, solvent distillation to a residual volume of $900 \mathrm{~mL}$ and precipitation at $0{ }^{\circ} \mathrm{C}$ ).

The site-selective monoacylation of the sugar moiety of useful glycosides has been also patented. For instance, acylation of polydatin (3,4,5-trihydroxystilbene-3- $\beta$-D-glucopyranoside), a pharmacological compound isolated from the root and rhizome of the traditional Chinese medicinal plant Polygonum cuspidatum, widely applied in anti-inflammatory, anti-oxidant and in anti-angiogenesis chemotherapy [131,132], has been reported in a patent from Huaiyin Institute of Technology, granted in 2018 [133]. This process, depicted in Scheme 14a, uses immobilized lipase from C. antarctica (Novozym 435?), amongst others, in 2-MeTHF, a biogenic solvent considered a renewable alternative to THF and other organic solvents $[33,134]$, to furnish almost quantitative yields of 36 , the monoacyl derivative at the $\mathrm{OH}$ group at $\mathrm{C} 6$ of the glucopyranoside moiety, a useful prodrug of polydatin. 
a)<smiles>[R]C(=O)OC(=O)OCC</smiles>

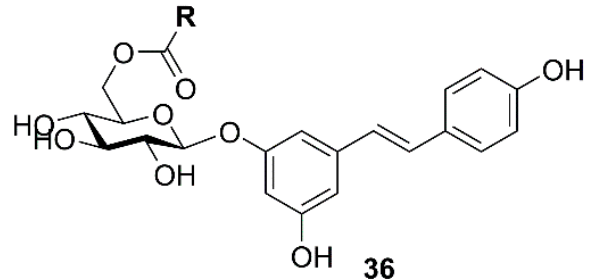

$$
\begin{aligned}
\mathbf{R}= & -\left(\mathrm{CH}_{2}\right)_{8}-\mathrm{CH}=\mathrm{CH}_{2}\left(12 \mathrm{~h}, 50^{\circ} \mathrm{C}, 97 \% \text { yield }\right) \\
& -(\mathrm{CH}=\mathrm{CH})-\mathrm{CH}_{3}(E)\left(36 \mathrm{~h}, 65^{\circ} \mathrm{C}, 100 \% \text { yield }\right) \\
& -(\mathrm{CH}=\mathrm{CH})_{2}-\mathrm{CH}_{3}(E, E)\left(5 \mathrm{~h}, 65^{\circ} \mathrm{C}, 997 \% \text { yield }\right)
\end{aligned}
$$

b)
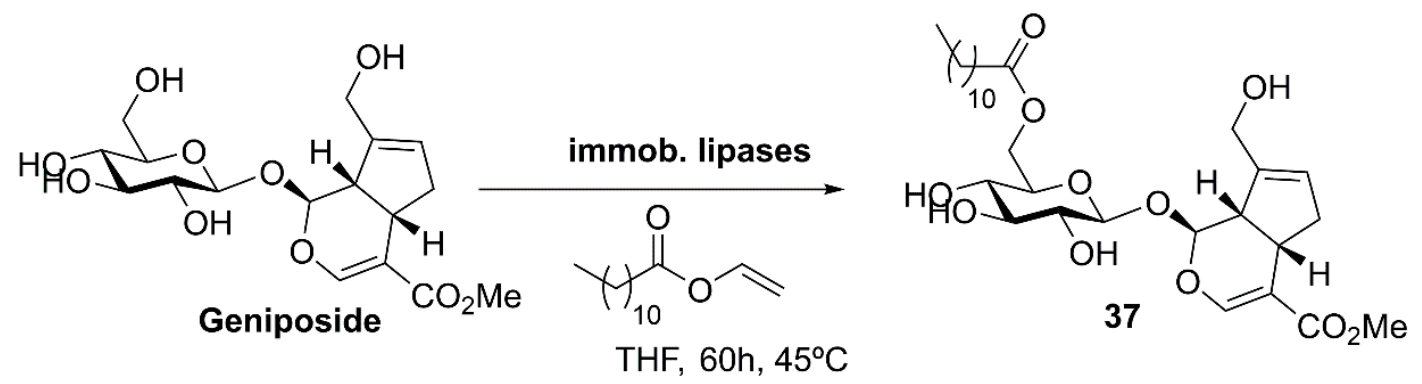

Scheme 14. (a) Cont. (b) Regioselective monoacylation of glycosides.

Geniposide is an important component of Gardenia jasminoides Ellis, a plant from Yinchenhao Tang, useful in the prevention and therapy of hepatic injury (HI) [135]. The site-selective monoacylation of geniposide (Scheme 14b) to furnish the more active and stable C-6'-lauroyl monoester has been reported in a patent from Nanjing Tech University, granted in 2019 [136], using different lipases ( $R h$. miehei, lipases A and B from C. Antarctica (Novozym 435?)) adsorbed on silica gel (easily separated by filtering after reaction) in THF at $45^{\circ} \mathrm{C}$ (yields up to $78 \%$ ).

In another example, the monoacetylation of (Z)-5-ethylidene-8-hydroxy-7-((3-hydroxypyridin-4-yl) methyl)-3,4,5,6,7,8-hexahydro-1H-pyrano[3,4-c]pyridin-1-one (38, Scheme 15), derived from the iridiod-type aglycon of multi-active swertiamarine [137-139], is reported in a patent from Jiangxi Science \& Technology Normal University granted in 2018 [140]. In this patent, compound 38 is obtained by a controlled fermentation of Swertia mussoti dry roots using cells from Aspergillus niger, isolated and acylated with vinyl acetate and Novozym 435 to provide 39 (acylated only in the aromatic OH group, no yield reported), an alkaloid which anti-hepatitis and anticancer activity seems to be very promising.

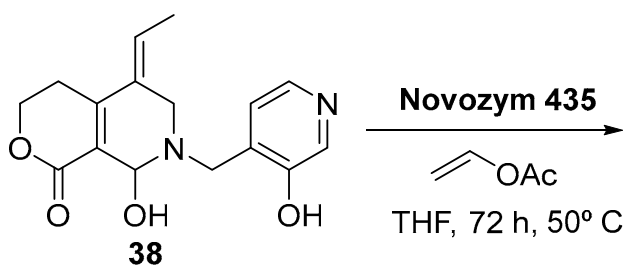<smiles>C/C=C1\CN(Cc2ccncc2OC(C)=O)C(O)C2=C1CCOC2=O</smiles>

Scheme 15. Regioselective monoacylation of the iridiod-type compound 38.

\subsubsection{Other Recently-Granted Patents Using Lipases}

Apart from the previous examples presented so far, some other patents have reported the use of lipases for hydrolysis [141,142] or acylations [143-147] taking advantage of the very mild reaction conditions in which they were carried out. Particularly interesting are those granted patents reporting the opening of $\delta$-valerolactone and $\varepsilon$-caprolactone with mercapto-alcohols catalyzed by Novozym 435 for the preparation of polymers [148], or the lipase-catalyzed preparation of enantiopure $(R)$ and $(S)$-leucine [149]. On the other hand, the in-situ reaction of vinyl acetate with isopropanol in the presence of $C$. antarctica lipase B as catalyst to obtain acetaldehyde from the vinyl alcohol (following 
a previously described strategy [150]) is used in a Biginelli reaction with a $\beta$-dicarbonyl compound, urea and water to produce different 3,4-dihydro-pyrimidin-2(1H)-ones, useful for the preparation of dark blue solid fluorescent materials [151].

To finish this section, we will illustrate an example of the well-known lipase promiscuity $[68,86,152,153]$. Thus, in a patent from Nanjing Tech University granted in 2018 [154], different lipases (lipase from pig pancreas (PPL) leading to the best results) were used for catalyzing the Knoevenagel condensation between indolin-2-one (Scheme 16, 40) and different aromatic aldehydes 41 to synthesize the corresponding 3-arylidene derivatives $\mathbf{4 2}$, useful in the synthesis of indole alkaloids with many therapeutic activities (antibacterial, antitumor or anti-inflammatory). Different reaction conditions were tested (solvent, temperature, etc.), being the best results obtained with a mixture of water/DMSO $(1 / 4, \mathrm{v} / \mathrm{v})$ and $45^{\circ} \mathrm{C}$.

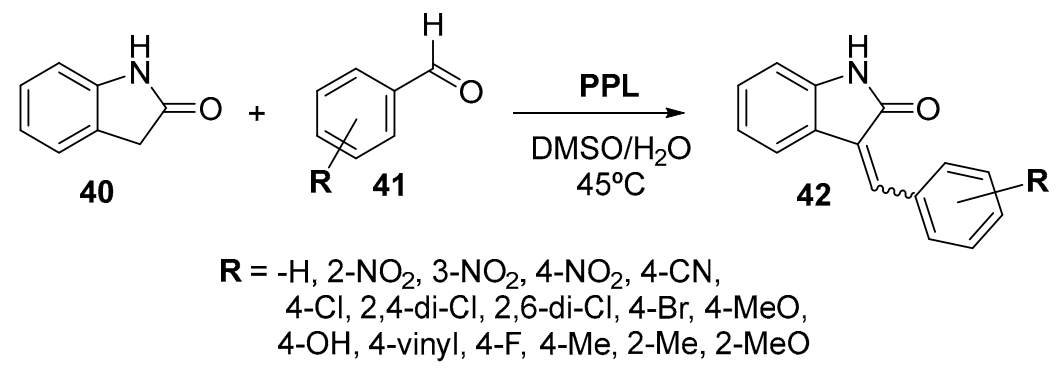

Scheme 16. Lipase-catalyzed Knoevenagel condensations.

\subsection{Other Hydrolases}

Apart from lipases (see the previous section), other types of hydrolases have been subject of IP protection as well. For instance, novel specific sequences of esterases have been patented and successfully employed in the kinetic resolution of esters of mandelic acid [155], phenyl ethanol [156], lactate derivatives [157], or cocaine [158], as well as for the synthesis of vetiveryl esters [147]. Moreover, some esterases have been used in the penicillin production area, like in the synthesis of 3-deacetyl-7-aminocephalosporaic acid [159].

Likewise, nitrilases have been extensively characterized and protected over the last five years. Companies like BASF [160-163] and c-LEcta [164] have patented novel sequences of nitrilases, with potential use in biocatalysis in asymmetric synthesis. In addition, some other activities cover sequences applied to specific targets for pharmaceuticals and fine chemicals. For instance, nitrilases are used to generate chirality in the synthesis of precursors of L-praziquantel, a drug employed against parasitic worm infections $[165,166]$. Nitrilases from Arabidopsis thaliana, Aspergillus niger or Alcaligenes faecalis are claimed in a patent granted in 2014 from Suzhou Tongli Biomedicine Co., Ltd., to perform the kinetic resolution of nitrile $\mathbf{4 3}$ (Scheme 17) [167] to obtain the enantiopure (R)-43, needed for the synthesis of the required drug.

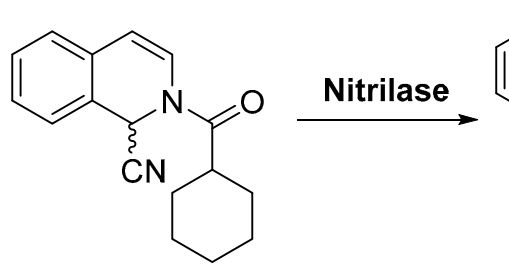

$(R, S)-43$<smiles>O=C(O)[C@H]1c2ccccc2C=CN1C(=O)C1CCCCC1</smiles>

(S) -44<smiles>C[C@@]1(C#N)c2ccccc2C=CN1C(=O)C1CCCCC1</smiles>

(R)-43<smiles>O=C(C1CCCCC1)N1CC(=O)N2C=Cc3ccccc3C2C1</smiles>

L-Praziquantel

Scheme 17. Use of nitrilases in the synthesis of L-praziquantel. 
Using nitrilases, other patents cover the asymmetric synthesis of $\beta$-alanine from $\beta$-aminopropionitrile at high substrate loadings $\left(>200 \mathrm{~g} \mathrm{~L}^{-1}\right)$ [168], an improved process for the production of pregabalin (see Scheme 34, below), the active agent in Lyrica ${ }^{\circledR}$, a drug employed in the treatment of epilepsy, neuropathic pain and fibromyalgia $[169,170]$ starting from dinitrile substrates (developed by Hikal Ltd) [171,172], or the production of 1-cyancyclohexylacetic acid by means of engineered nitrilases, and starting from the dinitrile substrate as well [173]. In another example, the synthesis of $(R)-46$, a precursor of ivabradine $\left(\right.$ Corlanor $^{\circledR}$, Procoralan $^{\circledR}$, Coralan $^{\circledR}$, Corlentor $^{\circledR}$, Lancora ${ }^{\circledR}$ or Coraxan ${ }^{\circledR}$, a drug prescribed for the symptomatic management of stable heart-related chest pain and heart failure [174,175]) has been developed and patented by Servier [176] (granted in 2015), using a nitrilase to generate the chirality through hydrolysis of the racemic nitrile $(R, S)-45$ to furnish the carboxylic acid (R)-46, as depicted in Scheme 18.

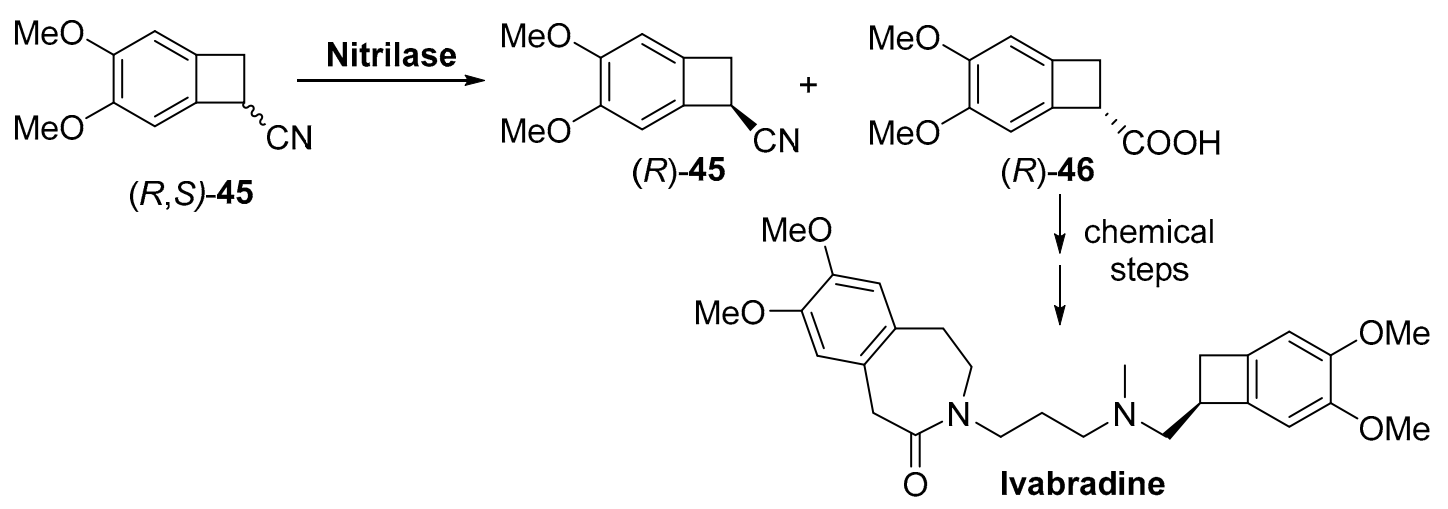

Scheme 18. Synthesis of precursors of the drug ivabradine using nitrilases.

Likewise, nitrilases have been used in the asymmetric synthesis of the statin side-chain, by hydrolysing the nitrile group [177-179]. The combination of nitrilases with halohydrin dehalogenases enables a continuous process for the efficient production of that important building block with high productivities and selectivities [179]. As reported in Section 2.1.3, the statin field is one of the most active ones when biocatalysis applied to IP generation is concerned. Other examples involving nitrilases cover the synthesis of pharmaceutical drugs like fosamprenavir [180], as well as clopidogrel [181]. Apart from nitrilases, penicillin $\mathrm{G}$ acylases have been used for the synthesis of optically active phenylglycine derivatives (through kinetic resolution strategies) [182].

\section{Granted Patents Related to Oxidoreductases in Asymmetric Synthesis}

\subsection{Ketone Reductions}

Alcohol dehydrogenases (ADHs; E.C. 1.1.1.x), also called ketoreductases (KREDs) or carbonyl reductases (CRs), are oxidoreductases that selectively catalyze the reversible conversion of carbonyl compounds into the corresponding alcohols, requiring the presence of nicotinamide cofactors (NADH or NADPH) to perform their activity. During the course of the reduction, the enzyme delivers a hydride from the cofactor C4 to the Si- (anti-Prelog ADHs) or to the Re-face (Prelog enzymes) of the carbonyl compound, yielding $(R)$ - or (S)-alcohols, respectively [183-187]. Efficient cofactor regeneration methodologies are required due to the high costs of nicotinamides and inhibition processes. Thus, the biocatalyzed reduction is coupled with a secondary reaction to regenerate the nicotinamide cofactors [188-190]. In general, a second enzymatic reaction is employed, for example by combining glucose with glucose dehydrogenase $(\mathrm{GDH})$, glucose-6-phosphate with glucose-6-phosphate dehydrogenase $(\mathrm{G} 6 \mathrm{PDH})$ or sodium formate with formate dehydrogenase $(\mathrm{FDH})$. NAD(P)H can also be regenerated by using a coupled substrate approach, in which the ADH catalysed the desired bioreduction and the oxidation of a cosubstrate, in general isopropanol (IPA), which is oxidized to acetone. Ketone reduction is under thermodynamic control, so that a large excess of IPA is required. 
Over the last five years, several procedures describing the use of KREDs for the preparation of valuable compounds have been patented.

Thus, a patent granted to Codexis Inc. described the preparation of ezetimibe (Zetia ${ }^{\circledR}$, Ezetrol ${ }^{\circledR}$, amongst other), a drug employed to treat high blood cholesterol and other lipids abnormalities [191-193], using different engineered KREDs from Lactobacillus brevis, Lactobacillus kefir and Lactobacillus minor in a patent granted in 2014 [194]. The ezetimibe precursor 5-((4S)-2-oxo-4-phenyl-(1,3-oxazolidin-3-yl))-1-(4-fluorophenyl)pentane-1,5-dione (47) was selectively reduced to (4S)-3-[(5S)-5-(4-fluorophenyl)-5-hydroxypentanoyl]-4-phenyl-1,3-oxazolidin-2-one (48), as depicted in Scheme 19a, with complete selectivity and conversions higher than $95 \%$ after 24 h. Glucose and glucose dehydrogenase (GHD) were employed as secondary enzymatic system to regenerate the $\mathrm{NADP}^{+}$consumed during the bioreduction. Substrate concentrations were at least of $100 \mathrm{~g} / \mathrm{L}$ whereas $5 \mathrm{~g} / \mathrm{L}$ of biocatalyst can be employed.<smiles>O=C(CCCC(=O)N1C(=O)OCC1c1ccccc1)c1ccc(F)cc1</smiles>

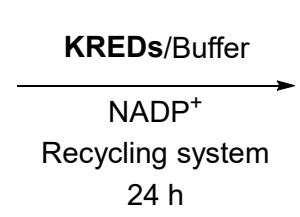<smiles>O=C(CCCC(O)c1ccc(F)cc1)N1C(=O)OC[C@@H]1c1ccccc1</smiles><smiles>O=C(CC[C@@H]1C(=O)N(c2ccc(F)cc2)C1c1ccc(O)cc1)c1ccc(F)cc1</smiles>

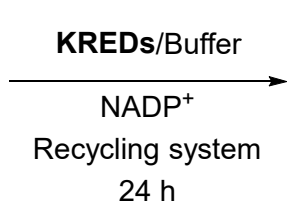<smiles>O=C1[C@H](CCC(O)c2ccc(F)cc2)C(c2ccc(O)cc2)N1c1ccc(F)cc1</smiles>

c)

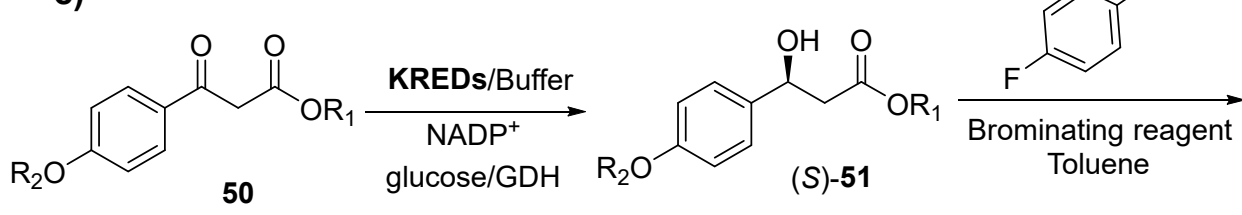

$\mathrm{R}_{1}$ : C1-C4 Alkyl

$(S)-51$

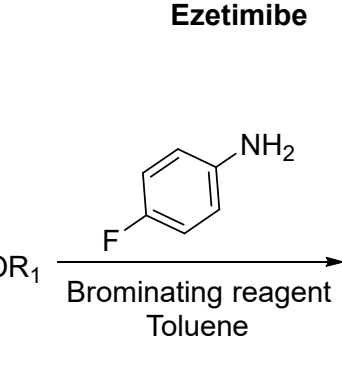

$\mathrm{R}_{2}$ : Ac, MOM, benzoyl, benzyl, THP.<smiles>O=C1C[C@H](c2ccc(O)cc2)N1c1ccc(F)cc1</smiles>

$(S)-52$

Scheme 19. Synthesis of ezetimibe employing KREDs.

The preparation of ezetimibe and some of its derivatives was also described in a further patent, also by Codexis Inc., granted in 2015 [195]. Bioreduction of 1-(4-fluorophenyl)-3(R)-[3-(4-fluorophenyl)-3 -oxopropyl]-4(S)-(4-hydroxyphenyl)-2-azetidinone (49, Scheme 19b) was carried out by an engineered KRED from Lactobacillus kefir, which sequence is given. Ezetimibe was obtained with excellent diastereomeric excess (>99\%) and high conversion (90\%) after $24 \mathrm{~h}$, being possible to use $50 \mathrm{~g} / \mathrm{L}$ of substrate. Different $\mathrm{NAD}(\mathrm{P})^{+}$regeneration systems were employed, including a set of secondary enzymatic systems with dehydrogenases and the use of the coupled-substrate approach in presence of IPA. Ezetimibe synthesis was also described through a chemoenzymatic route in a patent granted in 2018 [196], shown in Scheme 19c. The reduction of different $O$-protected $\beta$-ketoesters $\mathbf{5 0}$ was carried out in presence of a recombinant ketoreductase leading to the $\beta$-hydroxy-esters ( $S)$-51 with high optical purities ( $>95 \%$ ) and yields higher than $90 \%$ after $24 \mathrm{~h}$. Both IPA as cosubstrate or glucose/GDH 
as secondary enzymatic system were employed for the cofactor regeneration system. The chiral $\beta$-hydroxyesters were employed to prepare an Ezetimibe intermediate (S)-52 by bromination with different brominating reagents in presence of $p$-fluoroaniline and toluene as solvent (Scheme 19c). Immobilized KREDs have been also employed for the preparation of an ezetimibe precursor, as reported in a patent granted in 2018 [197]. Different techniques were applied to immobilize the biocatalyst, including adsorption, covalent binding, entrapping or cross-linked microencapsulated. Chiral alcohol was obtained with complete conversion after $18 \mathrm{~h}$, using IPA or the glucose/GDH system for the nicotinamide cofactor regeneration.

The efficacy of statins, inhibitors of the 3-hydroxy-3-methylglutaryl-coenzyme A (HMG-CoA) reductase, against all the forms of hypercholesterolemia and for the prevention of cardiovascular events [110] has been already mentioned in Section 2.1.3. In the last years, some patents employing ketoreductases have been published for the preparation of these compounds. Thus, in 2016 a patent was granted [198] describing the use of an engineered bacterium for the preparation of (3R,5S)-6-chloro-3,5-dihydroxyhexanoic acid tert-butyl ester (3R,5S)-55, a chiral precursor of statins. The engineered bacteria contained an ADH gene from Lactobacillus kefir DSM20587 (ADHR), a carbonyl reductase gene and a glucose dehydrogenase gene for the nicotinamide cofactor regeneration (Scheme 20a). The bacterial resting cells were employed in the bioreduction of 6-chloro-3,5-carbonyl hexanoate (53) in the presence of glucose and isopropanol in order to obtain the chiral diol $(3 R, 5 S)-55$ with complete selectivity and high yields in a two-step procedure. In 2017, another patent was granted reporting the preparation of a set of statins using a chemoenzymatic methodology [199]. Thus, KRED-130, commercially available from Codexis, was able to reduce the keto group of the intermediate $\mathbf{5 6}$ to the corresponding chiral alcohol $(R)-\mathbf{5 7}$ with quantitative yield and optical purities higher than $99.5 \%$ (Scheme 20b). A year later, a set of diketones intermediates in the preparation of statins were selectively reduced by different KREDs to the corresponding chiral 1,3-diols in a process carried out in buffer containing some organic solvents as ethanol, acetonitrile, toluene or hexane, among others [200]. Depending on the substrate structure, the chiral diols were obtained with yields around $90 \%$ and excellent optical purities after $24 \mathrm{~h}$.

a)

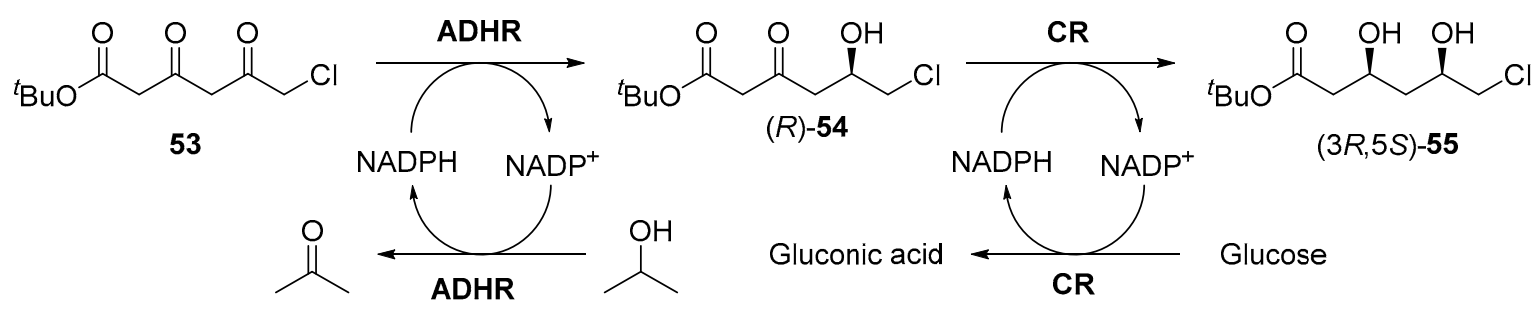

b)

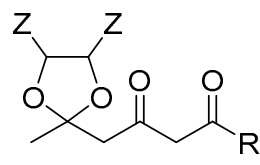

56

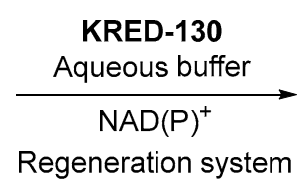

$25-40^{\circ} \mathrm{C}$

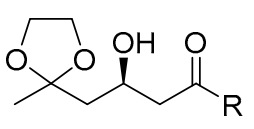

$(R)-57$

R: Alkyl.

Z: H, Alkyl, COOR

Scheme 20. Synthesis of statin intermediates employing ketoreductases.

Montelukast (Airon ${ }^{\circledR}$, Everest $^{\circledR}$, Singulair ${ }^{\circledR}$, Sansibast ${ }^{\circledR}$, Senovital ${ }^{\circledR}$, Accord $^{\circledR}$, amongst others) is an efficient and low toxicity anti-inflammatory, anti-allergy and asthma treatment compound [201-203]. In 2015, a patent describing the preparation of a montelukast sodium intermediate was granted [204]. The key step of this synthesis was the selective bioreduction of compound 58 (Scheme 22) catalyzed 
by an alcohol dehydrogenase in buffer containing an organic solvent as hexane or toluene. IPA was employed as cosubstrate in order to regenerate the NAD ${ }^{+}$cofactor. After $72 \mathrm{~h}$, the chiral alcohol (S)-59 can be recovered with high yield and selectivity, and converted to the desired intermediate ( $S$ )- 60 by treatment with methylmagnesium halide, as shown in Scheme 21. A year later, in a patent granted to Zhangjiagang Xinyi Chemical Co., a set of KREDs from Suzhou-Enzyme Biological Technology Co. were also employed in the bioreduction of the montelukast intermediate 58 to yield optically active alcohol (S)-59 [205]. Bioreductions were carried out in buffer containing toluene as cosolvent using $\mathrm{NADP}+$ as cofactor.<smiles>CC(=O)c1ccccc1CCC(=O)c1cccc(/C=C/c2ccc3ccc(Cl)cc3n2)c1</smiles>

58<smiles>COc1cccc(C=Cc2ccc3ccc(Cl)cc3n2)c1</smiles>

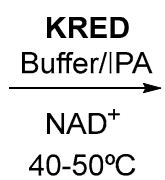

$10-72 \mathrm{~h}$<smiles>CC(=O)c1ccccc1CC[C@@H](O)c1cccc(/C=C/c2ccc3ccc(Cl)cc3n2)c1</smiles>

(S)-59

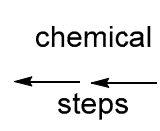<smiles>CC(C)(O)c1ccccc1CC[C@@H](O)c1cccc(/C=C/c2ccc3ccc(Cl)cc3n2)c1</smiles>

(S)-60

Scheme 21. Preparation of montelukast intermediates employing KREDs under mild reaction conditions.

The biocatalytic conversion of oxcarbazepine $\mathbf{6 1}$ and analogues to chiral (S)-eslicarbazepine (S)-62 (a drug employed in the treatment of epilepsy [206]) and corresponding chiral alcohols is reported in a patent granted in 2015 [207] using engineered ketoreductases from Lactobacillus, as shown in Scheme 22. These biocatalysts were able to selectively reduce the starting ketones with optical purities and conversions higher than $90 \%$ after $24 \mathrm{~h}$, depending on the substrate structure.<smiles>NC(=O)N1c2ccccc2CC(=O)c2ccccc21</smiles>

61

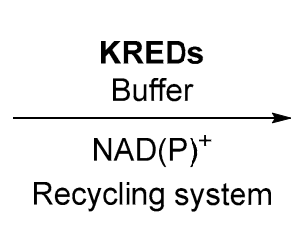

Scheme 22. Synthesis of (S)-eslicarbazepine (S)-62 employing KREDs.<smiles>NC(=O)N1c2ccccc2C[C@@H](O)c2ccccc21</smiles>

$(S)-62$

A patent covering a multistep synthesis of a set of $\beta$-3-antagonists [208] with a pyrrolidine core 65 [209] (Scheme 23) has been granted in 2017 to Merck Sharp \& Dohme Corp. [210]. One of these steps comprises the use of four engineered KREDs, whose sequence is given, for the bioreduction of a set of $\alpha$-aminoketones 63 to the corresponding $\beta$-aminoalcohols 64 in a dynamic kinetic resolution (Scheme 23) [211], leading to the stereoselective preparation of one of the diastereomers of the final alcohol with excellent yields and optical purities. Reactions were performed in presence of several cosolvents, whereas different enzymatic systems were tested for the nicotinamide cofactor recycling. 


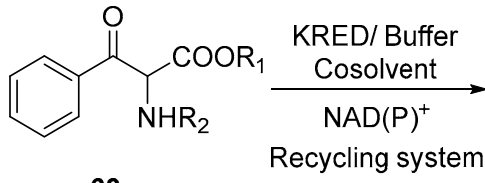

63<smiles>[R2]N[C@H](C(=O)O[R2])[C@@H](O)c1ccccc1</smiles>

$(2 S, 3 R)-64$

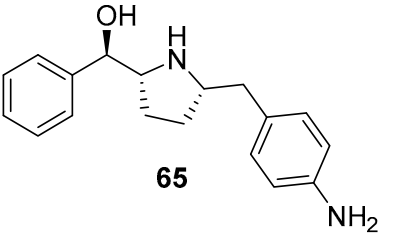

$\mathrm{R}_{1}$ : Alkyl

$\mathrm{R}_{2}$ : Boc, Cbz, FMOC, Ns.

Scheme 23. KREDs employed in the synthesis of different $\beta$-aminoalcohol intermediates of $\beta$-3-antagonists.

Dehydroepiandrosterone (DHEA, 66) is a key intermediate in the synthesis of steroidal molecules [212]. In 2018, a granted patent included a novel approach for preparing this valuable compound by carrying out the bioreduction of the 3-oxo group of the ${ }^{5} \Delta$-androstene-3,17-dione 65 in presence of KREDs obtained from Sphingomonas wittichii [213]. DHEA could be obtained with yields around $80-90 \%$ and selectivities higher than $90 \%$, being only observed the reduction of the 3-oxo group, when working at substrate concentrations of 50-300 g/L (Scheme 24). Some organic solvents immiscible with water can be employed in the bioreductions in concentrations around 25-75\%, and different secondary enzymatic systems were used to regenerate the $\mathrm{NAD}(\mathrm{P})^{+}$cofactor. The biocatalytic synthesis of DHEA has been also described in a patent granted in 2019 [214] by carrying out the same reduction at the 3-oxo positon of 65 in presence of an engineered KRED. The process was developed employing the KRED as a powder and using GDH from Bacillus subtilis and glucose for the NADP ${ }^{+}$recycling or using whole cells containing both enzymes. Substrate can be employed at concentrations around 120-600 g/L, furnishing enantiopure DHEA with high yields.

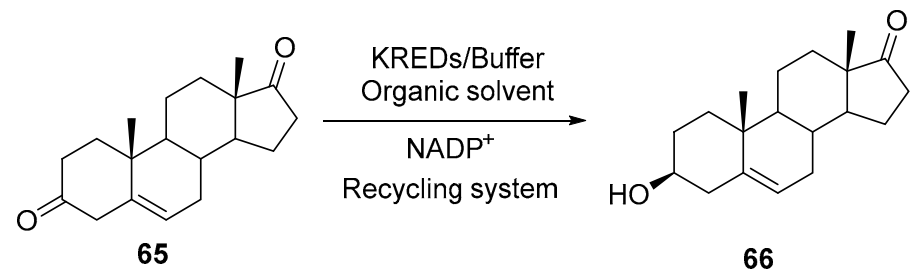

Scheme 24. Synthesis of DHEA 66 employing dehydrogenases.

A patent for the preparation of $(1 R, 2 S)-N$-pyrrolidinyl norephedrine 68 by a bioreduction procedure has been granted to Enzymeworks in 2019 [215]. This chiral compound is a valuable synthon for the preparation of anti-AIDS drug efavirenz (Sustiva ${ }^{\circledR}$ ) $[216,217]$. The starting ketone 67 was selectively reduced in dynamic kinetic resolution catalysed by a KRED purchased from Suzhou Chinese Biotechnology of Enzymes Co. (EW104), as indicated in Scheme 25. Isopropanol or glucose/GDH were employed for the cofactor recycling. After reaction parameters optimization, enantiopure $(1 R, 2 S)-68$ was recovered in high yields and with excellent purity.

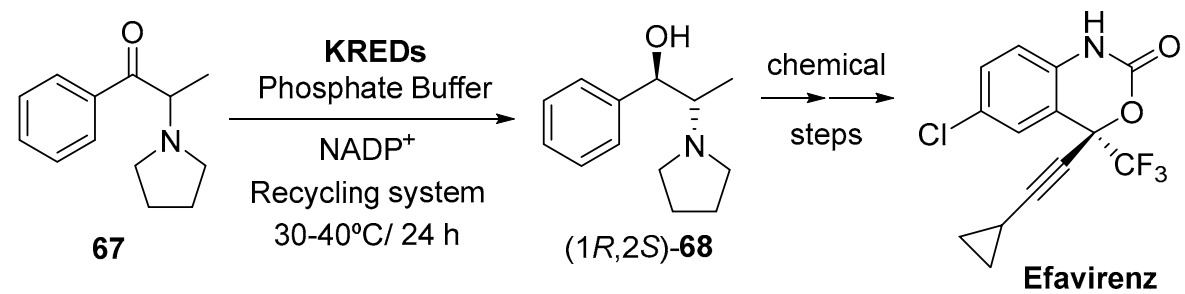

Scheme 25. Preparation of $(1 R, 2 S)-N$-pyrrolidinyl norephedrine employing ketoreductases.

A patent granted to Goodee Pharma Co. Ltd. in 2016 described the preparation of different 3-piperidinols by employing two KREDs, which sequence is given, as biocatalysts [218]. The enzymes 
were employed in solution or as lyophilized powders or immobilized as free enzymes or as whole cells, being employed glucose/GDH as secondary enzymatic system for the cofactor regeneration.

The application of a set of KREDs for the enantioselective reduction of different thienyl ketones to the corresponding (S)-thienyl alcohols with excellent optical purities ( $>99 \%$ ee) and high conversions has been patented in 2018 [219]. Alcohols thus obtained are valuable chiral synthons for the preparation of duloxetine [220-222], the active enantiomer of this third generation antidepressant trademarked as Cymbalta ${ }^{\circledR}$. A patent granted in 2015 to Codexis Inc. afforded the bioreduction of a family of 3-aryl-3-ketopropanamines to (S)-3-aryl-3-hydroxypropanamines employing different engineered KREDs, whose sequences are given [223]. Depending on the substrate structures, high conversions were obtained after $24 \mathrm{~h}$ employing glucose/GDH for the $\mathrm{NAD}(\mathrm{P})^{+}$recycling. The preparation of (S)-N,N-dimethyl-3-hydroxy-3-(2-thienyl)-1-propanamine ((S)-DHTP, 70), a precursor in the synthesis of duloxetine, was carried out with high yields from ketone 69 (Scheme 26). (S)-DHTP synthesis has been also described in a patent granted to Jiangnan University in 2019 [224]. The bioreduction of the starting ketone was carried out in the presence of different ketoreductases from different microorganisms, achieving the best results using a recombinant carbonyl reductase from Candida macedoniensis AKU 4588. Control of the reaction conditions allows obtaining (S)-DHTP in $92 \%$ yield and $99 \%$ ee.<smiles>CN(C)CCC(=O)c1cccs1</smiles>

69

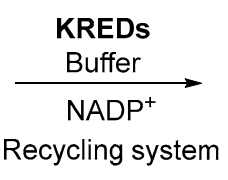

Recycling system<smiles>CN(C)CCC(O)c1cccs1</smiles>

70<smiles>Fc1cccc2ccccc12</smiles><smiles>CNCC[C@H](Oc1ccc2ccccc2c1)c1cccs1</smiles>

Duloxetine

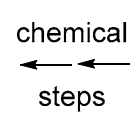

steps<smiles>CN(C)CCC(Oc1ccc2ccccc2c1)c1cccs1</smiles>

$(S)-71$

Scheme 26. Synthesis of duloxetine employing chemoenzymatic methodologies with ketoreductases.

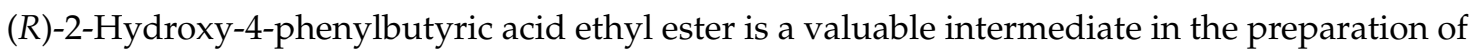
drugs employed to treat hypertension [225]. Its synthesis with a global yield of $82 \%$ starting from benzaldehyde and pyruvic acid has been patented by Suzhou Lead Biotechnology Company Ltd. [226]. The final step of this procedure comprises the bioreduction of 2-oxo-4-phenylbutyric acid ethyl ester in presence of glucose/GDH for the $\mathrm{NADP}^{+}$recycling. After $20 \mathrm{~h}$ at $30^{\circ} \mathrm{C}$ a $97 \%$ of the enantiopure $\beta$-hydroxyester was recovered in this process. Similarly, in 2019, Genentech Inc. was granted a patent [227] for the synthesis of (S)-1-(1-(4-chloro-3-fluorophenyl)-2-hydroxyethyl)-4-(2-((1-methyl-1Hpyrazol-5-yl)amino)pyrimidin-4-yl)pyridin-2(1H)-one (74), an ERK inhibitor and a useful medicament for treating hyperproliferative disorders [228]. One of the steps for the preparation of this compound, depicted in Scheme 27, comprises the bioreduction of 1-(4-chloro-3-fluorophenyl)-2-hydroxyethanone (72) to (S)-1-(4-chloro-3-fluorophenyl)ethane-1,2-diol (S)-73 catalyzed by KRED-NADH-112 (Codexis Inc.) using glucose/GDH for the $\mathrm{NAD}^{+}$recycling. The chiral alcohol was recovered with quantitative conversion and $99.5 \%$ ee. 

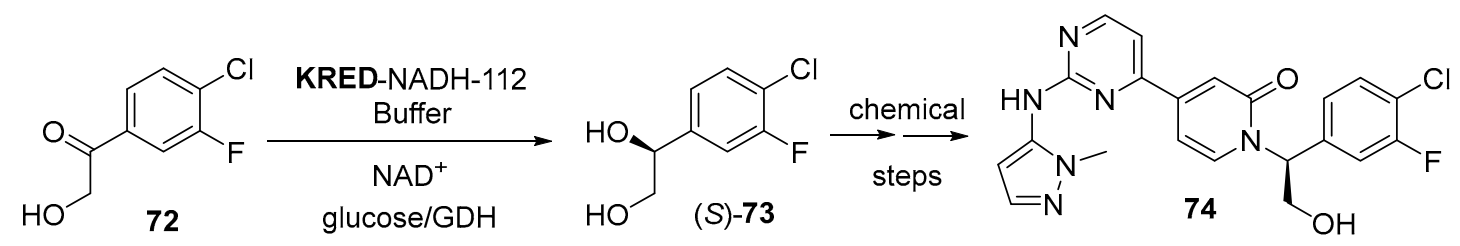

Scheme 27. The bioreduction of $\mathbf{7 2}$ to $(S)-73$ in the preparation of the anticancer drug $\mathbf{7 4}$.

Finally, fluoride-containing chiral alcohols are valuable compounds with a huge range of applications in medicine, pesticides or liquid crystals [229]. A patent granted to Enzymeworks in 2019 described the preparation of (S)-1,1,1-trifluoroisopropanol from trifluoroacetone employing different KREDs [230]. Phosphate buffer $\mathrm{pH} 7.0$ was used as reaction medium containing different amounts of organic cosolvents. $\mathrm{NADP}^{+}$was recycled in presence of glucose/GDH and a fluorinated reagent was added at the end of the bioreduction in order to extract the product from the reaction media. Thus, HFE-7600 and/or F-626 were used for this purpose, being able to recover quantitatively the final alcohol with $98.2 \%$ ee. The preparation of other halogenated alcohols has been granted by Codexis Inc. in 2015 [231]. Thus, the patent described the preparation of chiral $\alpha$-chloroalcohols from $\alpha$-chloroketones as well as the polynucleotides encoding the engineered ketoreductases and the host cells capable of expressing the engineered ketoreductases.

\subsection{Imine Reductions}

In the last few years, imine reductases (IREDs) have appeared as valuable biocatalysts for the preparation of chiral amines by catalyzing the reduction of imines [232-240]. These enzymes are involved in many natural processes such as the biosynthesis of cofactors, alkaloids and cyclic amino acids. IREDs are enzymes requiring $\mathrm{NAD}(\mathrm{P}) \mathrm{H}$, being this cofactor responsible of the imine reduction. In 2017 and 2018, two patents granted to Codexis Inc. showed different engineered enzymes with activity as imine reductases and applied these biocatalysts in the conversion of ketones and amines to the corresponding optically active secondary and tertiary amines, as for instance the conversion of cyclohexanone and L-norvaline to (S)-2-(cyclohexylamino)pentanoic acid [241,242]. On the other hand, a patent granted in 2016 to Pfizer Inc. [243] described the use of IRED in combination with an amine oxidase or a transaminase in one of the steps of the synthesis of pregabalin (discussed in Section 2.2, see also Scheme 34 in Section 4).

\subsection{Oxidations}

Oxidation processes involving different types of biocatalysts as mild oxidants under mild reaction conditions are employed are widely used nowadays while obtaining in general high selectivities [244-254]. For this reason, processes in which oxidative enzymes are employed have been patented in the last times. Most of the examples described the use of monooxygenases in different oxidations; these enzymes are able to perform the insertion of one atom of oxygen in the substrate from molecular oxygen, requiring nicotinamides as cofactors [255-259].

Esomeprazole (S)-76 (Scheme 28), is a proton pump inhibitor prescribed for the treatment of dyspepsia, peptic ulcer disease and gastroesophageal reflux disease [260]. This compound is the (S)-enantiomer of omeprazole, which is the racemic mixture of the $(S)$ and $(R)$ enantiomers. Thus, in a patent granted in 2016 [261] a set of engineered cyclohexanone monooxygenases (CHMOs) from Acinetobacter calcoaceticus [262] were employed in the asymmetric sulfoxidation of a set of prazoles, including 5-methoxy-2-((4-methoxy-3,5-dimethylpyridin-2-yl)methylthio)- $1 H$-benzodimidazole (75) (Scheme 28a). 
a)

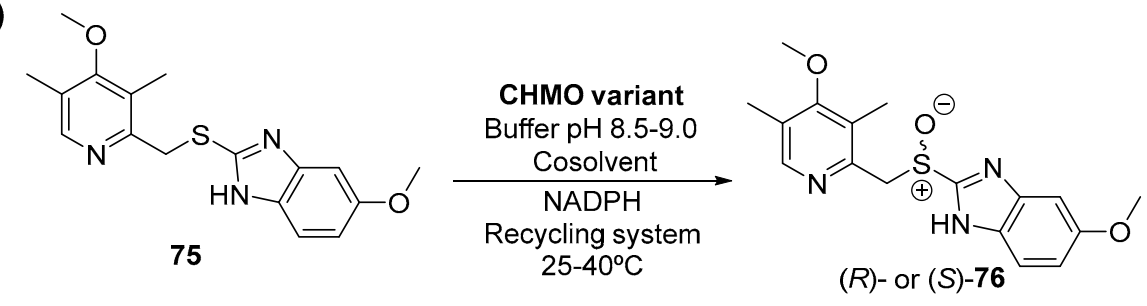

(S)-76 Esomeprazole

b)<smiles>NC(=O)CSC(c1ccccc1)c1ccccc1</smiles>

77

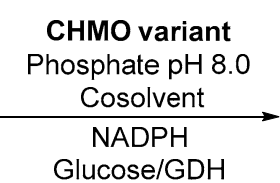

Glucose/GDH

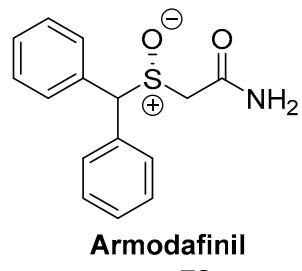

$(R)-78$

Scheme 28. Enzymatic sulfoxidations catalyzed by CHMO variants for the synthesis of esomeprazole (a) and armodafinil (b).

The oxidation of these compounds in presence of recombinant CHMOs afforded the corresponding $(R)$ - or $(S)$-sulfoxides $\mathbf{7 6}$ with excellent optical purities at mild temperatures. In order to ensure a complete conversion, dissolved molecular oxygen in the process can be increased by bubbling the reaction with oxygen-containing gas or by use of bubble-free aeration with oxygen-containing gas. Different organic cosolvents were tested in the processes ( $\mathrm{MeOH}, \mathrm{EtOH}, \mathrm{IPA}$, acetonitrile, etc.) to increase the substrate solubility. In order to regenerate the $\mathrm{NAD}(\mathrm{P}) \mathrm{H}$ employed as cofactor, secondary enzymatic systems including glucose/GDH, glucose-6-phosphate/glucose-6-phosphate dehydrogenase (G6PDH), formate/formate dehydrogenase (FDH), phosphite/phosphite dehydrogenase (PTDH) or alcohol/ADH were used.

Engineered CHMOs have been also employed in the preparation of armodafinil $((R)-78$, Scheme 28b) and analogues, as shown in a patent granted in 2017 to Codexis [263]. Armodafinil (Nuvigil ${ }^{\circledR}$ ) is the active $(R)$-enantiomer of the racemic drug modafinil (Provigil ${ }^{\circledR}$ ), employed for the treatment of narcolepsy and other medical conditions [264,265]. The sulfoxidation reaction was performed on both the amide substrate 2-(benzhydrylsulfinyl)acetamide 77 to obtain armodafinil, 2-(R)-(diphenylmethyl)sulfinylacetamide $(R)-\mathbf{7 8}$, or on the corresponding acid substrate, benzhydryl-thioacetic acid to yield ( $R$ )-2-(benzhydrylsulfinyl)acetic acid, known as $(R)$-modafinil (or modafinilic acid), which can be subsequently converted to the amide product in an easy way. For both processes, high optical purities were obtained (>90\% ee) under the optimized conditions when carrying out the oxidations in phosphate buffer in presence of different cosolvents.

The use of cytochrome P450 [255,256,259] has been also described in patents for the preparation of valuable compounds. Thus, in a patent granted in 2019 [266], different P450s obtained from Bacillus subtilis and Bacillus cereus expressed in E. coli, in combination with an electron-transfer protein having the activity to transfer an electron to the cytochrome P450, have been used as biocatalysts on the oxidation of the 3-methylene position of $\alpha$-guaiene 79 to lead (-)-rotundone 80, a molecule with several applications in the fragrance industry [267], as shown in Scheme 29. 


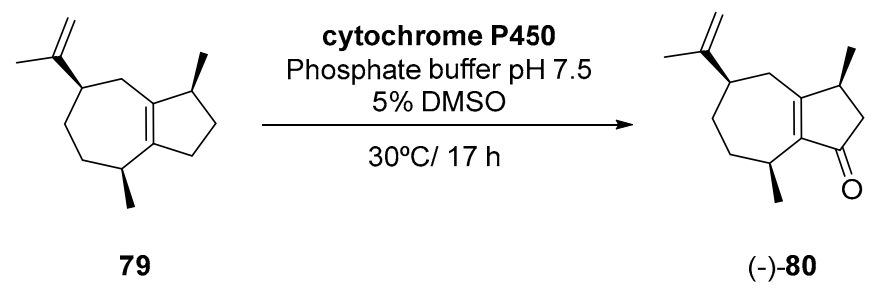

Scheme 29. Synthesis of (-)-rotundone employing E. coli cells expressing cytochrome P450s.

In 2015, Novozymes AS was granted a patent describing different fungal enzymes with peroxygenase activity [268]. Peroxygenases are biocatalysts capable of catalyse a very important process in organic chemistry such as the functionalisation of $\mathrm{C}-\mathrm{H}$ bonds through the hydroxylation of both non-activated and aromatic $\mathrm{C}-\mathrm{H}$ bonds $[252,254]$. The patent included the activity and compositions of these enzymes, their encoding polynucleotides, expression vectors and recombinant host cells as well as the methods of producing the enzymes. Finally, these biocatalysts were applied in the regioselective oxygenation of a set of $N$-heterocycles.

\section{Granted Patents Related to Transaminases in Asymmetric Synthesis}

Transaminases (TAs, type I and IV of pyridoxal 5'-phosphate (PLP)-dependent enzymes) are enzymes capable of catalysing the reversible transfer of an amino group from a suitable donor to a carbonyl acceptor. Of the two types of PLP-dependent TAs classified according to the type of substrate they convert [269], the use of $\alpha$-TAs, exclusively converting $\alpha$-amino and $\alpha$-keto acids, is more limited, while $\omega$-TAs can accept substrates with a distal carboxylate group. More specifically, amine TAs (ATAs), a subgroup of $\omega$-TAs, are capable of accepting substrates not possessing a carboxylate group in their structures, have received substantial attention in recent years, because of their capability in the synthesis of chiral primary amines starting from the corresponding prochiral ketones $[7,120,270]$.

Consequently, transaminase sequences have been protected in several granted documents. For instance, Hoffmann-La Roche and the Bornscheuer group have jointly patented (granted in 2018) several mutants of the transaminase from Ruegeria sp., which are useful for transamination synthetic reactions [271]. Likewise, Codexis has been active in identifying and protecting several transaminase sequences, with several patents granted between 2015-2019, with special emphasis on the production of (R)-ethyl-3-amino-3-(pyridine-2-yl)-propanoate derivatives [272-274]. An analogous sequence-based approach for IP construction has been successfully applied by DSM (patent granted in 2017 [275]) and Asymchem Laboratories (patent granted in 2019 [276]) with application of the novel transaminases to particularly impeded ketones as substrates (e.g., $m, m$-Cl-disubstituted phenyl-, or naphthyl acetophenones). Other examples describe the synthesis of L-aminobutyric acid, an intermediate in the synthesis of anti-epileptic levetiracetam (see also Scheme 1) in a patent granted in 2018 [277], as well as many other diverse synthetic purposes [278-280]. In the same field, the protection of novel transaminase sequences has been combined with immobilization [281-283], to be used, for instance, in the synthesis of antidiabetic sitagliptin (Januvia ${ }^{\circledR}$, a dipeptidyl peptidase-4 (DPP-4) inhibitor which was the first marketed oral antihyperglycemic drug belonging to the gliptin family [284]) through transamination [285-287], following the pioneering example described by Merck and Codexis [288].

With respect to asymmetric synthesis, there are several remarkable examples of granted patents using transaminases for the preparation of optically active amines, very relevant building blocks for pharmaceutical chemistry as already mentioned before in Section $2.1 .3[117,118,120]$. Herein, Lonza and the Bornscheuer group have jointly focused on the synthesis of $\mathrm{N}$-amino-pyrrolidines and piperidines, using transaminases with alanine as amino donor in two patents granted between 2014 and 2017 [289,290]; thus, the formed by-product pyruvate (from alanine) can be decarboxylated by means of a pyruvate decarboxylase (PDC), or reduced by using a dehydrogenase, to shift the equilibrium towards the product formation. In another example granted in 2017 [291], transaminases have been used for the synthesis of different 3-amino-pyrrolydines 82 and $\mathbf{8 6}$, starting from the correspondent functionalized 
oxopyrrolidines $\mathbf{8 1}$ and $\mathbf{8 4}$, using isopropyl-amine as amino donor (Scheme 30 ). The products formed undergo subsequent cyclization, and provide access to pyrrolo[3,4-b]pyridine structures 83 and $\mathbf{8 6}$, precursors of pharmaceuticals, e.g., the broad-spectrum antibiotic moxifloxacin (Avelox ${ }^{\circledR}$, Vigamox ${ }^{\circledR}$ or Moxiflox ${ }^{\circledR}$, amongst others) [292]. Remarkably, when the protecting group (PG) is an ester, the use of lipases (namely CALB) for the deprotection step is considered in the invention as well.
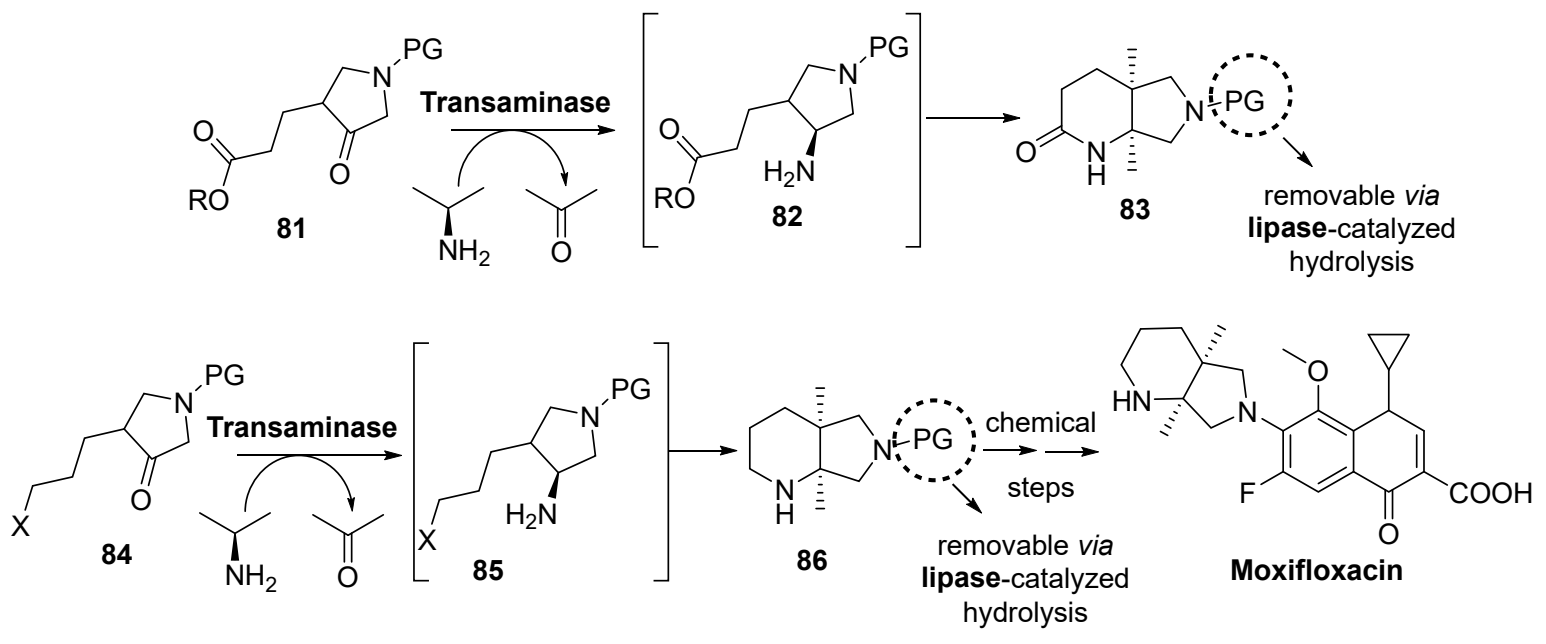

Scheme 30. Use of transaminases to afford 3-aminopyrrolidines, as precursors of pharmaceutical compounds, e.g., moxifloxacin.

Likewise, Codexis has described a patented process, granted in 2015 [293] for the synthesis of (1R,2R)-2-(3,4-dimethoxyphenethoxy)-cyclohexanamine $(R, R)-88$, starting from the correspondent enantiopure ketone $(R)-87$ by using specific sequences of transaminases, as depicted in Scheme 31 . The obtained amine is an intermediate in the synthesis of vernakalant, an ion channel blocker useful for the treatment of atrial fibrillation [294,295]. As amino donor, isopropyl-amine was used, and DMSO was added as co-solvent. Substrate loadings of $>10 \mathrm{~g} / \mathrm{L}$ have been claimed for the invention.<smiles>COc1ccc(CCOc2cc(CCO[C@H]3CCC[C@@H](N4CC[C@H](O)C4)[C@H]3OCCc3ccc(OC)c(OC)c3)ccc2OC)cc1OC</smiles>

Scheme 31. Use of transaminases for pharmaceutical precursors.

Following an analogous strategy, the same company has protected other synthetic routes, such as for (S)-3-(1-aminoethyl)-phenol ([296], granted in 2017), the synthesis of precursors of optically active lactams ([297], granted in 2015) and the preparation of aminocyclohexyl ether compounds ([298], also granted in 2015). Other applicants have protected the synthesis of aminocyclopamine through the enzymatic transamination of the corresponding ketocyclopamines [299], or for the synthesis of spiroindolones [300]. Finally, Evonik has been active in the valorization of biogenic resources, such as isosorbide, from which other building blocks like isomannide or isoidide can be derived; in this context, the use of transaminases and dehydrogenases has been recently protected [301].

With respect to aliphatic amines, several granted patents have been found as well. Enzymeworks has covered the use of transaminases to synthetize (S)-2-amino-1-butanol from the corresponding ketone. Several amino donors were used, and specific transaminases protected [302]. Another patent granted 
in 2018 [303] protects the synthesis of $(R, R)-90$, a precursor of efinaconazole (Jublia ${ }^{\circledR}$, Clenafin $\left.{ }^{\circledR}\right)$, an anti-fungal drug $[304,305]$, using transaminase variants able to accept the sterically hindered substrate (R)-89 (Scheme 32).<smiles>CC(=O)[C@](O)(Cn1cncn1)c1ccc(F)cc1F</smiles>

(R)-89

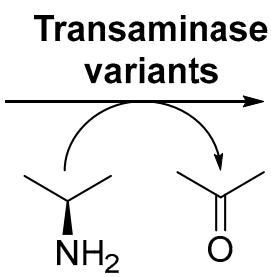

$\overbrace{O}^{O}$

91<smiles>C[C@H](N)[C@@](O)(Cn1cncn1)c1ccc(F)cc1</smiles>

$(R, R)-90$ chemical steps<smiles>C=C1CCN([C@@H](C)[C@@](O)(Cn2cncn2)c2ccc(F)cc2F)CC1</smiles>

Efinaconazole

talyzed synthesis of efinaconazole intermediates, using transaminases.

broad-spectrum herbicide [306], starting from the correspondent oxoacid 91 (Scheme 33). The specific sequence of the transaminase is provided as well in the patent granted in 2018 [307].

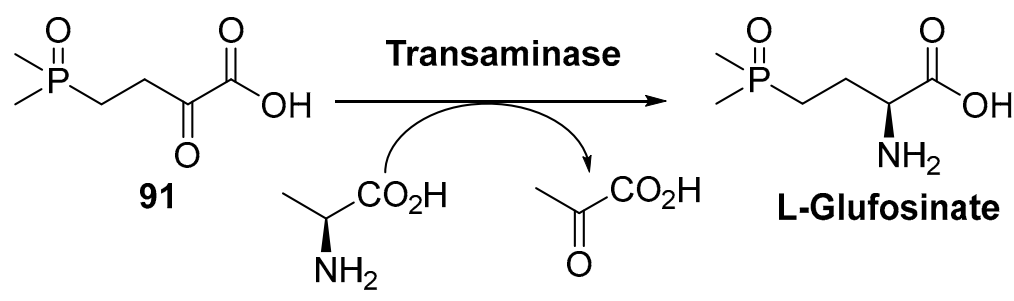

Scheme 33. Transaminase-catalyzed synthesis of L-glufosinate.

In the same field, the company Agrimetis LLC has patented a two-step enzymatic method for the synthesis of L-glufosinate, starting either from D-glufosinate or from the corresponding racemic mixture. In the first step, a D-amino acid oxidase forms the correspondent keto-acid, which is subsequently aminated by a transaminase in the second step [308]. The sequences of both enzymes are protected as well, and the immobilization of them is considered too.

Another active field is the synthesis of pregabalin (Lyrica ${ }^{\circledR}$ ), a medication used for anxiety disorder, epilepsy, neurophatic pains, fibromyalgia, restless leg syndrome, etc. $[169,170]$, already discussed in previous sections. In fact, Pfizer has patented a route ([243], granted in 2017), that covers all the synthetic steps for the generation of the amine precursor 92, which is then subjected to a transaminase-catalyzed reaction to introduce the chirality and produce pregabalin, as depicted in Scheme 34. The use of an amine oxidase or an imine reductase is considered and protected as well.<smiles>CCOC(=O)C[C@@H](C=O)CC(C)C</smiles>

92<smiles>CC(C)C[C@H](CN)CC(=O)[O-]</smiles>

Pregabalin

Scheme 34. Transaminase-catalyzed step for the synthesis of pregabalin, patented by Pfizer.

In an analogous area, Merck has patented a transaminase route ([309], granted in 2018) involving dynamic kinetic resolution for the synthesis of optically active amines, useful as precursors of drugs such as the anti-cancer agent niraparib [109]. 
As already shown in several examples (see above), the use of multi-step enzymatic processes is a rather common approach, as the properties of several biocatalysts can be combined for performing efficient asymmetric syntheses. Thus, MH2 Biochemical Ltd has patented a process for the synthesis of D-alanine, using racemases and amino transferases, being expressed as a fusion enzyme in a whole-cell [310]. In an analogous fashion, the use of lipases and transaminases are combined to deliver optically active $\beta$-amino acids, as well as precursors for the sitagliptin synthesis [311]. A further approach in this respect is the use of transaminases with opposite enantioselectivity for deracemization purposes, starting from racemic amino acids, as shown in Scheme 35 [312,313]. As depicted, the racemic $(R, S)-93$ is used as amino donor by a D-amino acid transaminase, rendering the desired amino acid (R)-95 from the keto acid $\mathbf{9 4}$. The subsequent byproduct, the keto acid 96, is recycled back to the racemic mixture by means of an (S)-transaminase, which uses isopropylamine as sacrificial amino donor. Overall, it represents an outstanding example on how the exquisite selectivity of enzymes may be smartly used for synthetic purposes.

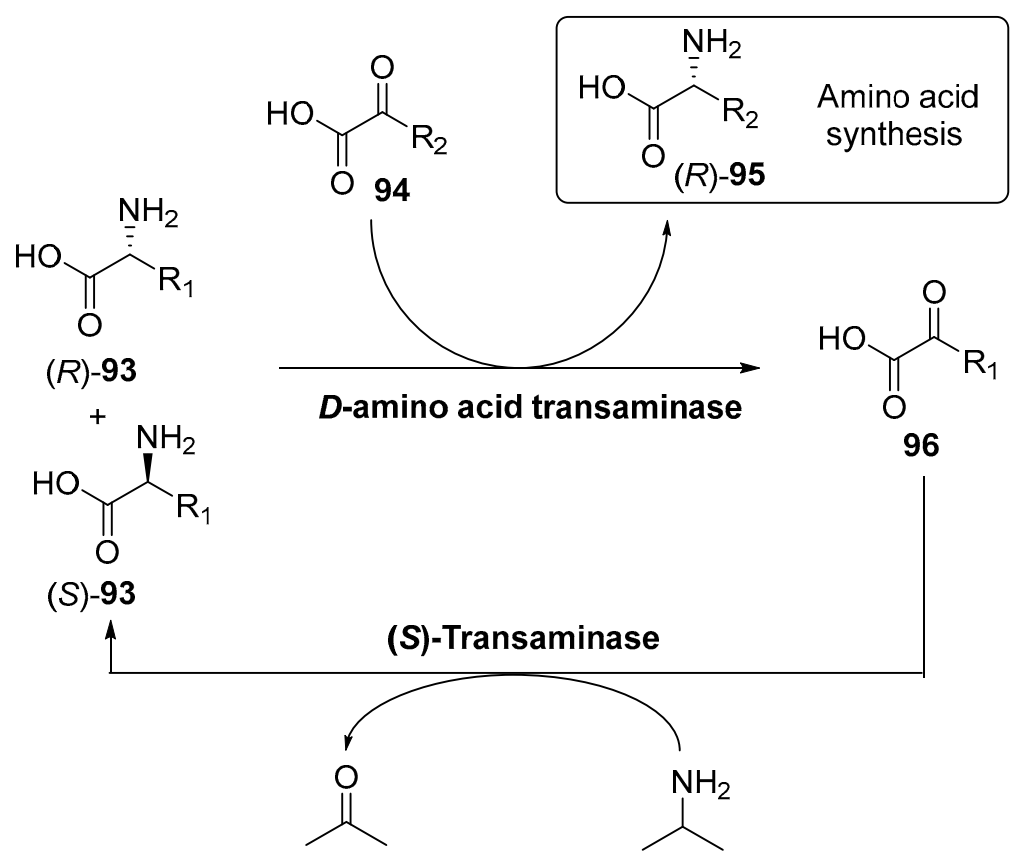

Scheme 35. Conceptual approach for production of optically active amino acids using two transaminases with opposite enantioselectivity.

\section{Granted Patents Related to Lyases in Asymmetric Synthesis}

Apart from other enzymes (see previous sections), lyases (EC 4.1.X.X, enzymes catalysing bond forming and breaking through non-hydrolytic or redox mechanisms) have also been matter of IP activity over the last five years, with relevant examples in the pharmaceutical and fine chemicals fields. As a common strategic working line for IP construction, several industries have focused on the (successful) protection of novel sequences of lyases (establishing several degrees of homology), which can be subsequently used for biocatalytic purposes. As relevant examples, Codexis was granted patents ([314], granted in 2019) that comprise examples of phenylammonia lyase variants (PAL, a C-N lyase [315]) with improved tolerance to $\mathrm{pH}$, higher activity, or resistance to enzymatic proteolysis (key amino acidic residues of the sequence are given). In a similar approach, another patent granted in 2019 [316] protect novel another C-N lyase, tyrosine ammonia lyase variants (TAL), with analogous focus on improved activities, and including thermostability as well. Likewise, BASF (Verenium) has protected ([317], granted in 2015) the use of ammonia lyases, covering PAL and TAL variants, and broadening their invention to histidine ammonia lyases as well. With a focus on other enzyme types, in a patent granted in 2015 [318], Firmenich has covered the sequence of a 13-hydroperoxide lyase 
(with an alteration of more than 40 amino acids compared to the wild-type sequence). The novel variant is employed in a reaction involving several polyunsaturated fatty acids (e.g., alpha-linolenic), to yield 3-(Z)-hexen-ol. Other examples are related to novel sequences of hydroxynitrile lyases, such as a patent granted 2018 of the Asano research group [319], or another one granted in 2015 from Evocatal [320]. Similarly, in a patent granted in 2014, DSM has protected hydroxynitrile lyases that can catalyze the asymmetric synthesis of sterically hindered cyanohydrins (e.g., starting from ortho-benzaldehyde derivatives as substrates) [321].

With respect to applications in asymmetric synthesis, tyrosine phenol lyases have found applications in the field of cathecol- and phenyl- amine derivatives. For instance, Changxing Pharmaceutical Ltd company has developed in a patent granted in 2018 [322] a process for the synthesis of L-DOPA, which is used as an anti-Parkinsonian drug [323-325]. In a similar area, the Rother group has protected in two patents granted 2018 and 2017 [326,327] the synthesis of the psychoactive drug cathine ((1S,2S)-nor-pseudoephedrine) [328,329], through a multi-step enzymatic reaction combining the use of Acetobacter pasteurianus pyruvate decarboxylase as (S)-selective lyase (C-C forming type [330,331]), together with the transaminase of Chromobacterium violaceum as (S)-selective transaminase, as depicted in Scheme 36.

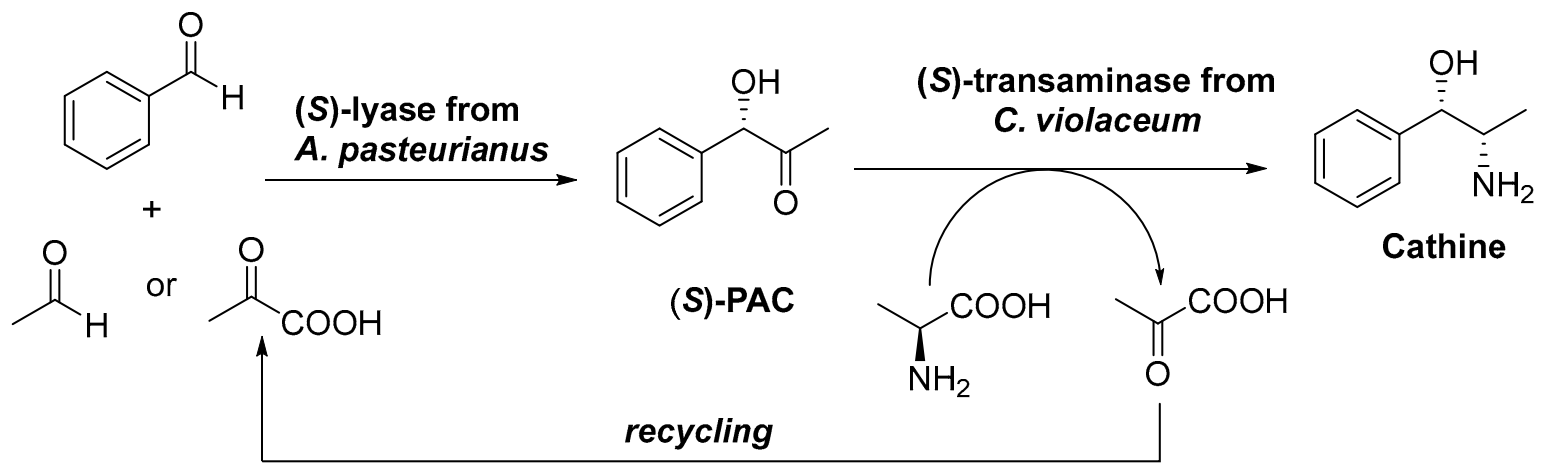

Scheme 36. Process for the synthesis of cathine, combining several enzymes and starting from inexpensive substrates.

As starting substrates, benzaldehyde and either acetaldehyde or pyruvic acid could be successfully employed. This has enabled the (re)use of pyruvic acid generated as by-product during the transaminase reaction when using L-alanine as amino donor, leading to a fully integrated multi-step enzymatic process with high selectivity and productivity to the desired compound [332,333]. The technology has been recently extended to other substrates (e.g., 2, 5-dimethoxybenzaldehyde) to afford other synthetically relevant building blocks [334].

Another relevant field of innovation with lyases (involving granted patents) is the synthesis of statins, from which many biocatalytic applications have been envisioned and comprehensively reviewed elsewhere [110], and some patents granted involving statins synthesis have been already commented on in Sections 2.1.3 and 3.1. Hence, several industries have been working on the use of lyases for this process, with different focuses to successfully build the IP. For instance, Lek Pharmaceuticals holds several patents granted in 2017 and 2018 [335-337], in which the innovation is based on the use of novel substrates, e.g., the use of 2,2-dimethoxyethanal to react with two equivalents of acetaldehyde, as well as on the use of aldolases (DERA) with novel sequences, and further enzymatic oxidation to the lactol derivative. An analogous strategy has been used by Pfizer, protecting novel DERA sequences to be used as catalysts for the reaction of $N$-protected substrates such as $\mathbf{9 9}$ and $\mathbf{1 0 0 . ~ S p e c i f i c a l l y , ~ t h e ~ i n t r o d u c t i o n ~}$ of 3-phtalimidopropionaldehyde $\mathbf{9 7}$ and 3-succinimido-propionaldehyde $\mathbf{9 8}$ as substrates (Scheme 37) has been successfully protected in a patent granted in 2014 [338]. 
<smiles>O=CCCN1C(=O)c2ccccc2C1=O</smiles>

or<smiles>O=CCCN1C(=O)CCC1=O</smiles>

DERAs with specific sequences<smiles>[Z2]C=O</smiles><smiles>O=C1c2ccccc2C(=O)N1CC[C@H]1C[C@@H](O)C[C@H](O)O1</smiles>

or<smiles>O=C1CCC(=O)N1CC[C@H]1C[C@@H](O)C[C@@H](O)O1</smiles>

Scheme 37. Pfizer approach, using several $N$-substituted substrates, for the synthesis of statins.

In a similar approach, Mitsui Chemicals has based its innovation patented in 2016 on the protection of a DERA with a specific sequence [339], whereas QR Pharmaceuticals Ltd has patented the use of carbamates as $\mathrm{N}$-protected substrates, to afford the synthesis of the statin side-chain using lyases ([340], granted in 2017).

Other examples of granted patents involving lyases are the synthesis of tagatose using novel variant sequences of fructose biphosphate aldolases [341,342], granted 2016 and 2015), or the synthesis of L-aminobutyric acid starting from glycine and ethanol as readily available substrates, and using a multi-sept process comprising an alcohol dehydrogenase, a threonine aldolase, a threonine deaminase, and a L-amino acid dehydrogenase ([343], granted 2018). Likewise, the Kroutil group has patented a process granted in 2016 [344,345] and presented in Scheme 38, in which $p$-vinyl- phenols 104 are produced along a three-step, one-pot reaction starting with substituted phenols 101, pyruvic acid and ammonia as substrates. Thus, the action of a tyrosine-phenol-lyase (TPL) leads to the formation of L-tyrosine derivatives (S)-102. Remarkably, chirality generated upon furnishing the corresponding aminoacids is afterwards destroyed along the course of the process. Subsequently, phenyl-ammonia lyase (PAL or TAL) renders the substituted $p$-coumaric acids 103 , which are finally decarboxylated by a phenolic-acid decarboxylase (PAD) to afford the desired $p$-vinylphenols 104 in high yields.

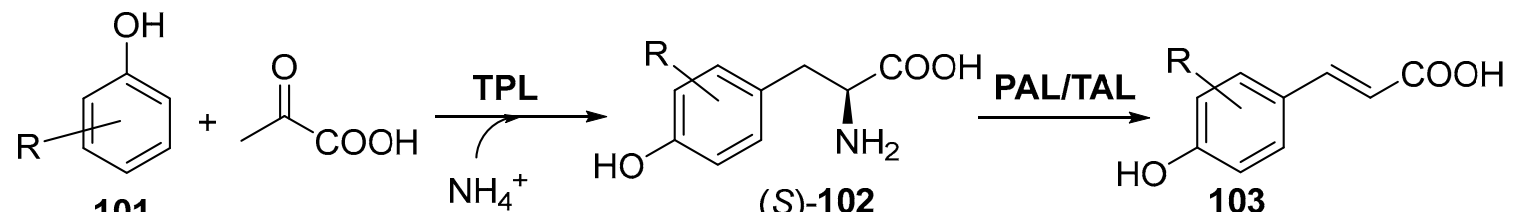

101

$(S)-102$

R: $2-\mathrm{F}, 2-\mathrm{Cl}, 2-\mathrm{Br}$

$2-\mathrm{Me}, 3-\mathrm{F}, 3-\mathrm{Cl}$<smiles>[R]c1c(O)ccc(C=C)c1CC(C)(C)C(=O)O</smiles>

104

20 examples

Yields $>97 \%$

Scheme 38. Biocatalytic formation of $p$-vinylphenols 104 catalyzed by a three-step one-pot reaction starting from readily available substrates. 


\section{Summary and Outlook}

Biocatalysis is an interdisciplinary field, in which the interaction of scientists with different backgrounds is necessary, namely, biology, chemistry, engineering, business, etc. On this basis, it offers many opportunities for innovation, and for the construction of novel IP structures. To reflect that innovation, a survey on patentability actions related to biocatalysis and asymmetric synthesis is given within this paper. To reinforce their innovative step, only granted patents have been considered. The result is a vast area of enzyme uses, covering all types, and performed by industry and academic groups. Several key ideas for innovation have been found. One is the protection of novel protein sequences for well-known reactions. Another one is the use of novel substrates for useful synthetic reactions. Further innovative lines (ending in granted patents) are the combination of different enzymes, as well as the set-up of other technical reaction parameters for improved processes. Based on the obtained results, it can be concluded that biocatalysis is taking significant steps in chemical industries, being seriously considered as a powerful alternative for combining sustainable chemistry with high efficiency and selectivity.

Author Contributions: All authors (P.D.d.M., G.d.G. and A.R.A.) equally contributed to this manuscript.

Funding: This research received no external funding.

Conflicts of Interest: The authors declare no conflict of interest.

\section{References}

1. Turner, N.J.; Kumar, R. Editorial overview: Biocatalysis and biotransformation: The golden age of biocatalysis. Curr. Opin. Chem. Biol. 2018, 43, A1-A3. [CrossRef] [PubMed]

2. Sheldon, R.A.; Brady, D. The limits to biocatalysis: Pushing the envelope. Chem. Commun. 2018, 54, 6088-6104. [CrossRef] [PubMed]

3. Rosenthal, K.; Lutz, S. Recent developments and challenges of biocatalytic processes in the pharmaceutical industry. Curr. Opin. Green Sustain. Chem. 2018, 11, 58-64. [CrossRef]

4. Raveendran, S.; Parameswaran, B.; Ummalyma, S.B.; Abraham, A.; Mathew, A.K.; Madhavan, A.; Rebello, S.; Pandey, A. Applications of microbial enzymes in food industry. Food Technol. Biotechnol. 2018, 56, 16-30. [CrossRef] [PubMed]

5. Li, G.Y.; Wang, J.B.; Reetz, M.T. Biocatalysts for the pharmaceutical industry created by structure-guided directed evolution of stereoselective enzymes. Bioorg. Med. Chem. 2018, 26, 1241-1251. [CrossRef] [PubMed]

6. Hughes, G.; Lewis, J.C. Introduction: Biocatalysis in Industry. Chem. Rev. 2018, 118, 1-3. [CrossRef] [PubMed]

7. Kelly, S.A.; Pohle, S.; Wharry, S.; Mix, S.; Allen, C.C.R.; Moody, T.S.; Gilmore, B.F. Application of Omega-Transaminases in the Pharmaceutical Industry. Chem. Rev. 2018, 118, 349-367. [CrossRef] [PubMed]

8. Hughes, D.L. Biocatalysis in drug development-highlights of the recent patent literature. Org. Process Res. Dev. 2018, 22, 1063-1080. [CrossRef]

9. Dorr, B.M.; Fuerst, D.E. Enzymatic amidation for industrial applications. Curr. Opin. Chem. Biol. 2018, 43, 127-133. [CrossRef]

10. Bornscheuer, U.T. The fourth wave of biocatalysis is approaching. Philos. Trans. R. Soc. A Math. Phys. Eng. Sci. 2018, 376, 20170063. [CrossRef]

11. Chapman, J.; Ismail, A.E.; Dinu, C.Z. Industrial Applications of Enzymes: Recent Advances, Techniques, and Outlooks. Catalysts 2018, 8, 238. [CrossRef]

12. Guajardo, N.; Domínguez de María, P. Continuous biocatalysis in environmentally-friendly media: A triple synergy for future sustainable processes. ChemCatChem 2019, 11, 3128-3137. [CrossRef]

13. Woodley, J.M. Accelerating the implementation of biocatalysis in industry. Appl. Microbiol. Biotechnol. 2019, 103, 4733-4739. [CrossRef] [PubMed]

14. Sheldon, R.A.; Brady, D. Broadening the Scope of Biocatalysis in Sustainable Organic Synthesis. ChemSusChem 2019, 12, 2859-2881. [CrossRef] [PubMed] 
15. Prier, C.K.; Kosjek, B. Recent preparative applications of redox enzymes. Curr. Opin. Chem. Biol. 2019, 49, 105-112. [CrossRef] [PubMed]

16. Bornscheuer, U.T.; Huisman, G.W.; Kazlauskas, R.J.; Lutz, S.; Moore, J.C.; Robins, K. Engineering the third wave of biocatalysis. Nature 2012, 485, 185-194. [CrossRef] [PubMed]

17. Foley, A.M.; Maguire, A.R. The Impact of Recent Developments in Technologies which Enable the Increased Use of Biocatalysts. Eur. J. Org. Chem. 2019, 2019, 3713-3734. [CrossRef]

18. Adams, J.P.; Brown, M.J.B.; Diaz-Rodriguez, A.; Lioyd, R.C.; Roiban, G.D. Biocatalysis: A Pharma Perspective. Adv. Synth. Catal. 2019, 361, 2421-2432. [CrossRef]

19. Domínguez de María, P.; de Gonzalo, G. Biocatalysis: An Industrial Perspective; Royal Society of Chemistry: London, UK, 2018.

20. Woodley, J.M. Bioprocess intensification for the effective production of chemical products. Comput. Chem. Eng. 2017, 105, 297-307. [CrossRef]

21. Ramesh, H.; Nordblad, M.; Whittall, J.; Woodley, J.M. Considerations for the Application of Process Technologies in Laboratory- and Pilot-Scale Biocatalysis for Chemical Synthesis. In Practical Methods for Biocatalysis and Biotransformations 3; John Wiley \& Sons, Ltd.: Hoboken, NJ, USA, 2016; pp. 1-30.

22. Woodley, J.M. Scale-Up and Development of Enzyme-Based Processes for Large-Scale Synthesis Applications. In Biocatalysis in Organic Synthesis, 2015 ed.; Faber, K., Fessner, W.D., Turner, N.J., Eds.; Georg Thieme Verlag: Stuttgart, Germany, 2015; pp. 515-546.

23. Lindeque, R.M.; Woodley, J.M. Reactor Selection for Effective Continuous Biocatalytic Production of Pharmaceuticals. Catalysts 2019, 9, 262. [CrossRef]

24. Reetz, M.T. Directed Evolution of Selective Enzymes: Catalysts for Organic Chemistry and Biotechnology; Wiley-VCH: Weinheim, Germany, 2017.

25. Madhavan, A.; Sindhu, R.; Binod, P.; Sukumaran, R.K.; Pandey, A. Strategies for design of improved biocatalysts for industrial applications. Bioresour. Technol. 2017, 245, 1304-1313. [CrossRef] [PubMed]

26. Rigoldi, F.; Donini, S.; Redaelli, A.; Parisini, E.; Gautieri, A. Review: Engineering of thermostable enzymes for industrial applications. APL Bioeng. 2018, 2, 17. [CrossRef] [PubMed]

27. Zeymer, C.; Hilvert, D. Directed evolution of protein catalysts. In Annual Review of Biochemistry; Kornberg, R.D., Ed.; Annual Reviews: Palo Alto, CA, USA, 2018; Volume 87, pp. 131-157.

28. Arnold, F.H. Directed Evolution: Bringing New Chemistry to Life. Angew. Chem. Int. Ed. 2018, 57, 4143-4148. [CrossRef] [PubMed]

29. Bornscheuer, U.T.; Hauer, B.; Jaeger, K.E.; Schwaneberg, U. Directed evolution empowered redesign of natural proteins for the sustainable production of chemicals and pharmaceuticals. Angew. Chem. Int. Ed. 2019, 58, 36-40. [CrossRef] [PubMed]

30. Bilal, M.; Iqbal, H.M.N. Tailoring Multipurpose Biocatalysts via Protein Engineering Approaches: A Review. Catal. Lett. 2019, 149, 2204-2217. [CrossRef]

31. De Gonzalo, G.; Alcántara, A.R.; Domínguez de María, P. Cyclopentyl Methyl Ether (CPME): A versatile eco-friendly solvent for applications in biotechnology and biorefineries. ChemSusChem 2019, 12, 2083-2097. [CrossRef]

32. Shanmuganathan, S.; Natalia, D.; van den Wittenboer, A.; Kohlmann, C.; Greiner, L.; Domínguez de María, P. Enzyme-catalyzed C-C bond formation using 2-methyltetrahydrofuran (2-MTHF) as (co)solvent: efficient and bio-based alternative to DMSO and MTBE. Green Chem. 2010, 12, 2240-2245. [CrossRef]

33. Pace, V.; Hoyos, P.; Castoldi, L.; Domínguez de María, P.; Alcántara, A.R. 2-Methyltetrahydrofuran (2-MeTHF): A Biomass-Derived Solvent with Broad Application in Organic Chemistry. ChemSusChem 2012, 5, 1369-1379. [CrossRef]

34. Hernáiz, M.; Alcántara, A.R.; García, J.I.; Sinisterra, J.V. Applied Biotransformations in Green Solvents. Chem. Eur. J. 2010, 16, 9422-9437. [CrossRef]

35. Cvjetko Bubalo, M.; Vidović, S.; Radojčić Redovniković, I.; Jokić, S. Green solvents for green technologies. J. Chem. Technol. Biotechnol. 2015, 90, 1631-1639. [CrossRef]

36. Clarke, C.J.; Tu, W.-C.; Levers, O.; Bröhl, A.; Hallett, J.P. Green and Sustainable Solvents in Chemical Processes. Chem. Rev. 2018, 118, 747-800. [CrossRef] [PubMed]

37. Lomba, L.; Zuriaga, E.; Giner, B. Solvents derived from biomass and their potential as green solvents. Curr. Opin. Green Sustain. Chem. 2019, 18, 51-56. [CrossRef] 
38. Sheldon, R.A. The greening of solvents: Towards sustainable organic synthesis. Curr. Opin. Green Sustain. Chem. 2019, 18, 13-19. [CrossRef]

39. Florindo, C.; Lima, F.; Ribeiro, B.D.; Marrucho, I.M. Deep eutectic solvents: Overcoming 21st century challenges. Curr. Opin. Green Sustain. Chem. 2019, 18, 31-36. [CrossRef]

40. Tomé, L.I.N.; Baião, V.; da Silva, W.; Brett, C.M.A. Deep eutectic solvents for the production and application of new materials. Appl. Mater. Today 2018, 10, 30-50. [CrossRef]

41. Guajardo, N.; Muller, C.R.; Schrebler, R.; Carlesi, C.; de Maria, P.D. Deep Eutectic Solvents for Organocatalysis, Biotransformations, and Multistep Organocatalyst/Enzyme Combinations. ChemCatChem 2016, 8, 1020-1027. [CrossRef]

42. Gotor-Fernandez, V.; Paul, C.E. Deep eutectic solvents for redox biocatalysis. J. Biotechnol. 2019, 293 , $24-35$. [CrossRef]

43. Paiva, A.; Matias, A.A.; Duarte, A.R.C. How do we drive deep eutectic systems towards an industrial reality? Curr. Opin. Green Sustain. Chem. 2018, 11, 81-85. [CrossRef]

44. Juneidi, I.; Hayyan, M.; Hashim, M.A. Intensification of biotransformations using deep eutectic solvents: Overview and outlook. Process Biochem. 2018, 66, 33-60. [CrossRef]

45. Maugeri, Z.; de Maria, P.D. Whole-Cell Biocatalysis in Deep-Eutectic-Solvents/Aqueous Mixtures. Chem CatChem 2014, 6, 1535-1537. [CrossRef]

46. Lin, B.; Tao, Y. Whole-cell biocatalysts by design. Microb. Cell Factories 2017, 16, 106. [CrossRef] [PubMed]

47. Wachtmeister, J.; Rother, D. Recent advances in whole cell biocatalysis techniques bridging from investigative to industrial scale. Curr. Opin. Biotech. 2016, 42, 169-177. [CrossRef] [PubMed]

48. Garzón-Posse, F.; Becerra-Figueroa, L.; Hernández-Arias, J.; Gamba-Sánchez, D. Whole cells as biocatalysts in organic transformations. Molecules 2018, 23, 1265. [CrossRef] [PubMed]

49. Grunwald, P. Immobilized Biocatalysts. Catalysts 2018, 8, 386. [CrossRef]

50. Rodrigues, R.C.; Virgen-Ortiz, J.J.; Dos Santos, J.C.S.; Berenguer-Murcia, A.; Alcantara, A.R.; Barbosa, O.; Ortiz, C.; Fernandez-Lafuente, R. Immobilization of lipases on hydrophobic supports: Immobilization mechanism, advantages, problems, and solutions. Biotechnol. Adv. 2019, 37, 746-770. [CrossRef]

51. Bernal, C.; Rodriguez, K.; Martinez, R. Integrating enzyme immobilization and protein engineering: An alternative path for the development of novel and improved industrial biocatalysts. Biotechnol. Adv. 2018, 36, 1470-1480. [CrossRef]

52. Facin, B.R.; Melchiors, M.S.; Valerio, A.; Oliveira, J.V.; de Oliveira, D. Driving immobilized lipases as biocatalysts: 10 years' state of the art and future prospects. Ind. Eng. Chem. Res. 2019, 58, 5358-5378. [CrossRef]

53. Rueda, N.; dos Santos, J.C.S.; Ortiz, C.; Torres, R.; Barbosa, O.; Rodrigues, R.C.; Berenguer-Murcia, A.; Fernandez-Lafuente, R. Chemical modification in the design of immobilized enzyme biocatalysts: Drawbacks and opportunities. Chem. Rec. 2016, 16, 1436-1455. [CrossRef]

54. DiCosimo, R.; McAuliffe, J.; Poulose, A.J.; Bohlmann, G. Industrial use of immobilized enzymes. Chem. Soc. Rev. 2013, 42, 6437-6474. [CrossRef]

55. Sheldon, R.A.; van Pelt, S. Enzyme immobilisation in biocatalysis: Why, what and how. Chem. Soc. Rev. 2013, 42, 6223-6235. [CrossRef]

56. Jesionowski, T.; Zdarta, J.; Krajewska, B. Enzyme immobilization by adsorption: A review. Adsorption 2014, 20, 801-821. [CrossRef]

57. Bilal, M.; Cui, J.D.; Iqbal, H.M.N. Tailoring enzyme microenvironment: State-of-the-art strategy to fulfill the quest for efficient bio-catalysis. Int. J. Biol. Macromol. 2019, 130, 186-196. [CrossRef] [PubMed]

58. Britton, J.; Majumdar, S.; Weiss, G.A. Continuous flow biocatalysis. Chem. Soc. Rev. 2018, 47, 5891-5918. [CrossRef] [PubMed]

59. Sheldon, R.A. The E factor 25 years on: The rise of green chemistry and sustainability. Green Chem. 2017, 19, 18-43. [CrossRef]

60. Tickner, J.A.; Becker, M. Mainstreaming green chemistry: The need for metrics. Curr. Opin. Green Sustain. Chem. 2016, 1, 1-4. [CrossRef]

61. Sheldon, R.A. Reaction efficiencies and green chemistry metrics of biotransformations. In Biocatalysis for Green Chemistry and Chemical Process Development; John Wiley and Sons, Inc.: Hoboken, NJ, USA, 2011; pp. 67-88. 
62. De Maria, P.D.; Hollmann, F. On the (Un)greenness of Biocatalysis: Some Challenging Figures and Some Promising Options. Front. Microbiol. 2015, 6, 5.

63. Daiha, K.D.; Angeli, R.; de Oliveira, S.D.; Almeida, R.V. Are lipases still important biocatalysts? A study of scientific publications and patents for technological forecasting. PLoS ONE 2015, 10, e0131624. [CrossRef] [PubMed]

64. Hughes, D.L. Highlights of the Recent, U.S. Patent Literature: Focus on Biocatalysis. Org. Process Res. Dev. 2016, 20, 700-706. [CrossRef]

65. Bornscheuer, U.; Kazlauskas, R.J. Hydrolases in Organic Synthesis. Regio-and Stereoselective Biotransformations, 2nd ed.; WILEY-VCH Verlag: Weinheim, Germany, 2006.

66. Busto, E.; Gotor-Fernandez, V.; Gotor, V.Hydrolases: Catalytically promiscuous enzymes for non-conventional reactions in organic synthesis. Chem. Soc. Rev. 2010, 39, 4504-4523. [CrossRef]

67. Siirola, E.; Frank, A.; Grogan, G.; Kroutil, W. C-C hydrolases for biocatalysis. Adv. Synth. Catal. 2013, 355, 1677-1691. [CrossRef]

68. Lopez-Iglesias, M.; Gotor-Fernandez, V. Recent advances in biocatalytic promiscuity: Hydrolase-catalyzed reactions for nonconventional transformations. Chem. Rec. 2015, 15, 743-759. [CrossRef]

69. Mendez-Sanchez, D.; Lopez-Iglesias, M.; Gotor-Fernandez, V. Hydrolases in organic chemistry. Recent achievements in the synthesis of pharmaceuticals. Curr. Org. Chem. 2016, 20, 1186-1203. [CrossRef]

70. Kazlauskas, R. Chapter 5-Hydrolysis and formation of carboxylic acid and alcohol derivatives. In Organic Synthesis Using Biocatalysis; Goswami, A., Stewart, J.D., Eds.; Academic Press: Cambridge, MA, USA, 2016; pp. 127-148.

71. Bertau, M.; Jeromin, G.E. Hydrolysis and transacylation: Esterases, lipases, phosphatases, and phosphoryl transferases. In Biocatalysis in Organic Synthesis, 2015 ed.; Faber, K., Fessner, W.D., Turner, N.J., Eds.; Georg Thieme Verlag: Stuttgart, Germany, 2015; Volume 1, pp. 129-187.

72. Liu, X.; Kokare, C. Microbial enzymes of use in Industry. In Biotechnology of Microbial Enzymes; Brahmachari, G., Ed.; Academic Press, Elsevier: Amsterdam, The Netherlands, 2017; pp. 267-298.

73. Sanchez, S.; Demain, A.L. Useful Microbial Enzymes-An Introduction. In Biotechnology of Microbial Enzymes; Brahmachari, G., Ed.; Academic Press, Elsevier: Amsterdam, The Netherlands, 2017; pp. 1-11.

74. Reetz, M.T. Lipases as practical biocatalysts. Curr. Opin. Chem. Biol. 2002, 6, 145-150. [CrossRef]

75. Roy, I.; Mukherjee, J.; Gupta, M.N. High Activity Preparations of Lipases and Proteases for Catalysis in Low Water Containing Organic Solvents and Ionic Liquids. In Immobilization of Enzymes and Cells, 3rd ed.; Guisan, J.M., Ed.; Humana Press: Totowa, NJ, USA, 2013; Volume 1051, pp. 275-284.

76. De Miranda, A.S.; Miranda, L.S.M.; de Souza, R. Lipases: Valuable catalysts for dynamic kinetic resolutions. Biotechnol. Adv. 2015, 33, 372-393. [CrossRef] [PubMed]

77. Seddigi, Z.S.; Malik, M.S.; Ahmed, S.A.; Babalghith, A.O.; Kamal, A. Lipases in asymmetric transformations: Recent advances in classical kinetic resolution and lipase-metal combinations for dynamic processes. Co-ord. Chem. Rev. 2017, 348, 54-70. [CrossRef]

78. Hills, G. Industrial use of lipases to produce fatty acid esters. Eur. J. Lipid Sci. Technol. 2003, 105, 601-607. [CrossRef]

79. Bornscheuer, U.T.; Flickinger, M.C. Lipases, synthesis of chiral compounds, aqueous and organic solvents. In Encyclopedia of Industrial Biotechnology; John Wiley \& Sons, Inc.: Hoboken, NJ, USA, 2009; Volume 5, pp. 1-12.

80. Tufvesson, P.; Tornvall, U.; Carvalho, J.; Karlsson, A.J.; Hatti-Kaul, R. Towards a cost-effective immobilized lipase for specialty chemicals. J. Mol. Catal. B Enzym. 2011, 68, 200-205. [CrossRef]

81. Ansorge-Schumacher, M.B.; Thum, O. Immobilised lipases in the cosmetics industry. Chem. Soc. Rev. 2013, 42, 6475-6490. [CrossRef]

82. Adlercreutz, P. Immobilisation and application of lipases in organic media. Chem. Soc. Rev. 2013, 42, $6406-6436$. [CrossRef]

83. Kumar, A.; Dhar, K.; Kanwar, S.S.; Arora, P.K. Lipase catalysis in organic solvents: Advantages and applications. Biol. Proced. Online 2016, 18, 2. [CrossRef]

84. Priyanka, P.; Tan, Y.Q.; Kinsella, G.K.; Henehan, G.T.; Ryan, B.J. Solvent stable microbial lipases: Current understanding and biotechnological applications. Biotechnol. Lett. 2019, 41, 203-220. [CrossRef] [PubMed]

85. Chakravorty, D.; Parameswaran, S.; Dubey, V.K.; Patra, S. Unraveling the rationale behind organic solvent stability of lipases. Appl. Biochem. Biotechnol. 2012, 167, 439-461. [CrossRef] [PubMed] 
86. Dwivedee, B.P.; Soni, S.; Sharma, M.; Bhaumik, J.; Laha, J.K.; Banerjee, U.C. Promiscuity of lipase-catalyzed reactions for organic synthesis: A recent update. ChemistrySelect 2018, 3, 2441-2466. [CrossRef]

87. Ji, Y.; Chen, B.; Qian, F.; He, Y.; Gao, X.; Hong, X. A Method for Preparing Levetiracetam. CN105063120B, 18 October 2015.

88. Ortiz, C.; Ferreira, M.L.; Barbosa, O.; dos Santos, J.C.S.; Rodrigues, R.C.; Berenguer-Murcia, A.; Briand, L.E.; Fernandez-Lafuente, R. Novozym 435: The perfect lipase immobilized biocatalyst? Catal. Sci. Technol. 2019, 9, 2380-2420. [CrossRef]

89. Ueda, T.; Abe, Y. Novel Method for Producing 1-(acyloxy)alkyl Carbamate Derivatives. WO2016208709A1, 29 December 2016.

90. Boffa, M.B.; Koschinsky, M.L. Curiouser and curiouser: Recent advances in measurement of thrombin-activatable fibirinolysis inhibitor (TAFI) and in understanding its molecular genetics, gene regulation, and biological roles. Clin. Biochem. 2007, 40, 431-442. [CrossRef] [PubMed]

91. Leurs, J.; Hendriks, D. Carboxypeptidase U (TAFla): A metallocarboxypeptidase with a distinct role in haemostasis and a possible risk factor for thrombotic disease. Thromb. Haemost. 2005, 94, 471-487. [CrossRef] [PubMed]

92. Colucci, M.; Semeraro, N. Thrombin activatable fibrinolysis inhibitor: At the nexus of fibrinolysis and inflammation. Thromb. Res. 2012, 129, 314-319. [CrossRef]

93. Zheng, G.; Chen, Q. Method for producing ticagrelor chiral drug intermediates by using Candida antarctica lipase B. CN104164469A, 26 November 2014.

94. Husted, S.; van Giezen, J.J.J. Ticagrelor: The first reversibly binding oral P2Y (12) receptor antagonist. Cardiovasc. Ther. 2009, 27, 259-274. [CrossRef]

95. Danielak, D.; Karazniewicz-Lada, M.; Glowka, F. Ticagrelor in modern cardiology-an up-to-date review of most important aspects of ticagrelor pharmacotherapy. Expert Opin. Pharmacother. 2018, 19, 103-112. [CrossRef]

96. Abrahamson, M.J.; Kielbus, A.B.; Riordan, W.T.; Hill, D.R.; Chemburkar, S.R.; Reddy, R.E.; Towne, T.B.; Mei, J.; Brown, G.J.; Mix, S. Enzymatic process for the preparation of (1S,2R)-2-(Difluoromethyl)-1-(propoxycarbonyl) cyclopropanecarboxylic Acid. US10316338B1, 11 June 2019.

97. Markham, A.; Goa, K.L. Valsartan-A review of its pharmacology and therapeutic use in essential hypertension. Drugs 1997, 54, 299-311. [CrossRef]

98. Xia, J.; Chen, D. Method for Preparing L-Valsartan by Separating DL-Valsartan Ester with Lipase. CN105420338A, 23 March 2016.

99. Xin, J.; Sun, L.; Wang, Y.; Chen, L. Preparation Method of 1,4-Dihydro-2,6-dimethyl-4-(3-nitrophenyl)-3, 5-pyridinedicarboxylic Acid Monomethyl Ester. CN106279000A, 4 January 2017.

100. Curtis, T.M.; Scholfield, C.N. Nifedipine blocks $\mathrm{Ca}^{2+}$ store refilling through a pathway not involving L-type $\mathrm{Ca} 2+$ channels in rabbit arterioral smooth muscle. J. Physiol. 2001, 532, 609-623. [CrossRef] [PubMed]

101. Hughes, A. Calcium Channel Blockers. In Hypertension: A Companion to Braunwald's Heart Disease, 3rd ed.; Bakris, G.L., Sorrentino, M.J., Eds.; Elsevier: Amsterdam, The Netherlands, 2018; pp. 242-253.

102. Chen, X.; Sun, D.; Sun, Q.; He, S.; Wang, C.; Zhuang, M.; Yang, Y.; Xie, K.; Guo, P. Preparation Method of High-Purity Ledipasvir Intermediate (1R,3S,4S)-2-(tert-Butoxycarbonyl)-2-azabicyclo[2.2.1]heptane-3 -carboxylic Acid. CN105461606A, 6 April 2016.

103. Link, J.O.; Taylor, J.G.; Xu, L.H.; Mitchell, M.; Guo, H.Y.; Liu, H.T.; Kato, D.; Kirschberg, T.; Sun, J.Y.; Squires, N.; et al. Discovery of Ledipasvir (GS-5885): A potent, once-daily oral NS5A Inhibitor for the treatment of hepatitis C virus infection. J. Med. Chem. 2014, 57, 2033-2046. [CrossRef] [PubMed]

104. Ku, L. Process for Synthesis of Posaconazole Intermediate 2-Methylpropionic Acid 4-(2,4-Difluorophenyl)-2-(2S)-hydroxymethyl-4-pentenyl Ester. CN105753693A, 13 July 2016.

105. Saksena, A.K.; Girijavallabhan, V.M.; Lovey, R.G.; Pike, R.E.; Wang, H.Y.; Ganguly, A.K.; Morgan, B.; Zaks, A.; Puar, M.S. Highly stereoselective access to novel 2,2,4-trisubstituted tetrahydrofurans by halocyclization-Practical chemoenzymatic synthesis of SCH-51048, a broad-spectrum orally-active antifungal agent. Tetrahedron Lett. 1995, 36, 1787-1790. [CrossRef]

106. Oberhuber, M.; Salchenegger, J.; De Souza, D.; Albert, M.; Wilhelm, T.; Langner, M.; Sturm, H.; Spitzenstaetter, H.P. Process for the Preparation of Chiral Triazolones. WO2011144653A1, 24 November 2011.

107. Langner, M.; De Souza, D.; Pise, A.C.; Bhuta, S. Method for Preparation and Purification of Posaconazole and Posaconazole Intermediates. WO2011144657A1, 24 November 2011. 
108. Kunic Tesovic, B. Purification of Posaconazole Intermediates. EP2789610A1, 2014.

109. Hoyos, P.; Pace, V.; Alcántara, A.R. Chiral building blocks for drugs synthesis via biotransformations. In Asymmetric Synthesis of Drugs and Natural Products; Nag, A., Ed.; CRC Press: Boca Raton, FL, USA, 2018; pp. 346-448.

110. Hoyos, P.; Pace, V.; Alcántara, A.R. Biocatalyzed synthesis of statins: A sustainable strategy for the preparation of valuable drugs. Catalysts 2019, 9, 260. [CrossRef]

111. Yu, C.; Zhai, M.; Wang, M.; Gong, X.; Zhang, T.; Zhai, H. Preparation Method of High-Purity Pitavastatin Calcium for Treating Hypercholesterolemia. CN103834705A, 15 October 2014.

112. Torres, F.; Rubin, L.J. Treprostinil for the treatment of pulmonary arterial hypertension. Expert Rev. Cardiovasc. Ther. 2013, 11, 13-25. [CrossRef] [PubMed]

113. Moriarty, R.M.; Rani, N.; Enache, L.A.; Rao, M.S.; Batra, H.; Guo, L.; Penmasta, R.A.; Staszewski, J.P.; Tuladhar, S.M.; Prakash, O.; et al. The intramolecular asymmetric Pauson-Khand cyclization as a novel and general stereoselective route to benzindene prostacyclins: Synthesis of UT-15 (treprostinil). J. Org. Chem. 2004, 69, 1890-1902. [CrossRef]

114. Wang, Q.; Wang, T.; Sun, Y.; Wang, B.; You, B.; Pu, J.; Li, X.; Jiang, Y. Preparation of Levocarnitine. CN106748843A, 31 May 2017.

115. Kraemer, W.J.; Volek, J.S.; Dunn-Lewis, C. L-Carnitine supplementation: Influence upon physiological function. Curr. Sports Med. Rep. 2008, 7, 218-223. [CrossRef]

116. Bloomer, R.J.; Butawan, M.; Farney, T.M.; McAllister, M.J. An Overview of the Dietary Ingredient Carnitine; Academic Press Ltd.: London, UK, 2019; pp. 605-617.

117. Gröger, H.J.A.M. Biocatalytic concepts for synthesizing amine bulk chemicals: Recent approaches towards linear and cyclic aliphatic primary amines and $\omega$-substituted derivatives thereof. Appl. Microbiol. Biotechnol. 2019, 103, 83-95. [CrossRef]

118. Kohls, H.; Steffen-Munsberg, F.; Höhne, M. Recent achievements in developing the biocatalytic toolbox for chiral amine synthesis. Curr. Opin. Chem. Biol. 2014, 19, 180-192. [CrossRef]

119. Grogan, G. Synthesis of chiral amines using redox biocatalysis. Curr. Opin. Chem. Biol. 2018, 43, 15-22. [CrossRef] [PubMed]

120. Gomm, A.; O’Reilly, E. Transaminases for chiral amine synthesis. Curr. Opin. Chem. Biol. 2018, 43, $106-112$. [CrossRef] [PubMed]

121. Ismail, H.; Lau, R.M.; van Rantwijk, F.; Sheldon, R.A. Fully enzymatic resolution of chiral amines: Acylation and deacylation in the presence of Candida antarctica lipase B. Adv. Synth. Catal. 2008, 350, 1511-1516. [CrossRef]

122. Bhardwaj, K.K.; Gupta, R. Synthesis of chirally pure enantiomers by lipase. J. Oleo Sci. 2017, 66, 1073-1084. [CrossRef] [PubMed]

123. Wang, J. Method for Preparation of (R)-2-Tetrahydronaphthylamine. CN104263801A, 7 January 2015.

124. Bruinvels, J. Evidence for inhibition of reuptake of 5-hydroxytryptamine and noradrenaline by tetrahydronaphthylamine in rat brain. Br. J. Pharmacol. 1971, 42, 281-286. [CrossRef]

125. Chen, Y. A Preparation Method of R-1-Aminoindane with Candida Rugosa Lipase as Biol. Resoln. Catalyzer. CN105063161A, 18 November 2015.

126. Oldfield, V.; Keating, G.M.; Perry, C.M. Rasagiline-A review of its use in the management of Parkinson's disease. Drugs 2007, 67, 1725-1747. [CrossRef] [PubMed]

127. McCormack, P.L. Rasagiline: A Review of Its Use in the Treatment of Idiopathic Parkinson's Disease. CNS Drugs 2014, 28, 1083-1097. [CrossRef]

128. Chen, Y. A Resolution Method for Preparing Optically Pure R-1-phenylethylamine. CN104152525A, 19 November 2014.

129. Gaboardi, M.; Pallanza, G.; Baratella, M.; Castaldi, G.; Castaldi, M. Chemoenzymic Preparation of Sofosbuvir Involving a Lipase Catalyzed Regioselective Deacetylation. WO2017144423A1, 31 August 2017.

130. Lawitz, E.; Mangia, A.; Wyles, D.; Rodriguez-Torres, M.; Hassanein, T.; Gordon, S.C.; Schultz, M.; Davis, M.N.; Kayali, Z.; Reddy, K.R.; et al. Sofosbuvir for previously untreated chronic hepatitis C infection. N. Engl. J. Med. 2013, 368, 1878-1887. [CrossRef]

131. Du, Q.H.; Peng, C.; Zhang, H. Polydatin: A review of pharmacology and pharmacokinetics. Pharm. Biol. 2013, 51, 1347-1354. [CrossRef] 
132. Sohretoglu, D.; Baran, M.Y.; Arroo, R.; Kuruuzum-Uz, A. Recent advances in chemistry, therapeutic properties and sources of polydatin. Phytochem. Rev. 2018, 17, 973-1005. [CrossRef]

133. Wang, C.; Du, W.; Bi, Y.; Yuan, X.; Yang, R.; Ding, C.; Zhao, X.; Zhou, W. Preparation of Polydatin Ester Derivative and Application Thereof. CN105503970A, 20 April 2016.

134. Alcántara, A.R.; Domínguez de Maria, P. Recent advances on the use of 2-methyltetrahydrofuran (2-MeTHF) in biotransformations. Curr. Green Chem. 2018, 5, 85-102. [CrossRef]

135. Zhang, A.; Sun, H.; Sun, W.; Wang, X. Metabolomics and proteomics annotate therapeutic mechanisms of geniposide. In Chinmedomics: The Integration of Serum Pharmacochemistry and Metabolomics to Elucidate the Scientific Value of Traditional Chinese Medicine; Elsevier Inc.: Amsterdam, The Netherlands, 2015; pp. 157-173.

136. Yao, Z.; Lu, Y.; Ni, F.; Zhu, B.; Sun, Y. Method for Catalytic Synthesis of C-6'-Lauroyl Geniposide by Lipase. CN106282272A, 4 January 2017.

137. Leong, X.Y.; Thanikachalam, P.V.; Pandey, M.; Ramamurthy, S. A systematic review of the protective role of swertiamarin in cardiac and metabolic diseases. Biomed. Pharmacother. 2016, 84, 1051-1060. [CrossRef] [PubMed]

138. Patel, N.; Tyagi, R.K.; Tandel, N.; Garg, N.K.; Soni, N. The molecular targets of swertiamarin and its derivatives confer anti-diabetic and anti-hyperlipidemic effects. Curr. Drug Targets 2018, 19, 1958-1967. [CrossRef] [PubMed]

139. Jun, C.; Xue-Ming, Z.; Chang-Xiao, L.; Tie-Jun, Z. Structure elucidation of metabolites of swertiamarin produced by Aspergillus niger. J. Mol. Struct. 2008, 878, 22-25. [CrossRef]

140. Chang, J.; Li, Y.; Guo, J.; Yao, L. Preparation of 3-(3-acetyl-4-methylpyridine)-NHHP. CN106543193A, 29 March 2017.

141. Paio, A.; Fogal, S.; Motterle, R. Enzymatic process for the preparation of testosterone and esters thereof. EP3064589A1, 2016.

142. Wang, Z.; Yan, J.; Hong, H.; Lin, Y. Process for Preparation of (3S)-5-amino-3-[[(1,1-dimethylethyl) dimethylsilyl]oxy]-5-oxo-pentanoic Acid. CN104356155A, 18 February 2015.

143. Stensrud, K.; Venkitasubramanian, P. Esterification of 2,5-furan-dicarboxylic acid. US20150315166A1, 5 November 2015.

144. Yamashita, M.; Kinsho, T. Chemoenzymic Preparation of (2R,12Z)-2-Benzoyloxy-12-heptadecene and (2S,12Z)-2-Hydroxy-12-heptadecene. US20160076063A1, 17 March 2016.

145. Yuan, Z.; Wang, Z.; Lv, P.; Luo, W.; He, D.; Li, Z.; Fu, J.; Li, H.; Miao, C.; Yang, L. A Method for Preparing Kojic Acid Dipalmitate by Composite Enzymatic Method. CN105296554A, 3 February 2016.

146. Li, M.; Li, Z. Enzymatic Resolution of Dl-Menthol with Ionic Liquid as Green Medium. CN104531823A, 22 April 2015.

147. Antoniotti, S.; Filippi, J.J.; Notar Francesco, I.; Ramilijaona, J. Biotechnological Manufacture of Vetiveryl Esters. WO2016193208A1, 8 December 2016.

148. Guo, K.; Huang, W.; Zhu, N.; Hu, X.; Fang, Z.; Liu, Y. Method for Using Microreactor to Prepare Mercapto Functionalized Polylactone. CN105969816A, 28 September 2016.

149. Jiang, L.; Fu, Q.; He, H.; Tang, S.; Gu, M. Enzymic Resolution of Racemic Leucine. CN103981248A, 13 August 2014.

150. Perez-Sanchez, M.; Dominguez de Maria, P. Lipase Catalyzed in Situ Production of Acetaldehyde: A Controllable and Mild Strategy for Multi-Step Reactions. ChemCatChem 2012, 4, 617-619. [CrossRef]

151. Yu, X.; Zhang, W.; Wang, N. Preparation of 3,4-Dihydro-pyrimidin-2(1H)-one Derivative and Application thereof. CN106588782A, 26 April 2017.

152. Kapoor, M.; Gupta, M.N. Lipase promiscuity and its biochemical applications. Process. Biochem. 2012, 47, 555-569. [CrossRef]

153. Arora, B.; Mukherjee, J.; Gupta, M. Enzyme promiscuity: Using the dark side of enzyme specificity in white biotechnology. Sustain. Chem. Process. 2014, 2, 25. [CrossRef]

154. Hu, Y.; Huang, H.; Ding, Y.; Gu, M.; Li, H.; Ni, X. Preparation of 3-Substituted-2-Indolinone Compound with Lipase. CN104818305A, 5 August 2015.

155. Hu, Y.; Liang, J.; Sun, A.; Zhang, Y.; Deng, D. A Method for Resolution of Methyl ( \pm )-Mandelate with Esterase. CN104830944A, 12 August 2015.

156. Hu, Y.; Liang, J.; Zhang, Y.; Sun, A.; Deng, D. Bacillus Esterase BSE01281 and Its Application in Resolution of ( \pm )-1-Phenylethanol and ( \pm )-Styralyl Acetate. CN104962533A, 7 October 2015. 
157. Hu, Y.; Wang, Y.; Zhang, Y. Esterase PHE1414 and Its Coding Gene, and Application as Catalyst in the Preparation of Thereof. CN105802935A, 27 July 2016.

158. Zhan, C.-G.; Zheng, F.; Fang, L. High Activity Variants of Cocaine Esterase for Cocaine Hydrolysis in the Treatment of Overdose. US20160122732A1, 5 May 2016.

159. Hou, H.; Wei, W.; Wang, M.; Cheng, J.; Wang, G.; Hu, B.; Li, J.; Yu, P. Enzymatic Preparation Method of 3-Deacetyl-7-Aminocephalosporanic Acid (D-7-Aca) from Cephalosporin C (Cpc) Sodium Salt by Utilizing Immobilized Cpc Acylase and Deacetylase. CN104480181A, 1 April 2015.

160. Wong, K.; Short, J.M.; Burk, M.J.; Desantis, G.; Farwell, R. Nitrilases, Nucleic Acids Encoding Them and Methods for Making and Using Them. US9315792B2, 19 April 2016.

161. Burk, M.; Chaplin, J.A.; Chi, E.; DeSantis, G.; Milan, A.; Robertson, D.; Short, J.M.; Weiner, D.P. Nitrilases. AU2013200739B2, 7 March 2013.

162. Chaplin, J.A.; Weiner, D.P.; Milan, A.; Chi, E.; Short, J.M.; Madden, M.; Burk, M.; Robertson, D.; DeSantis, G. Nitrilases. EP2327767A1, 1 June 2011.

163. Weiner, D.P.; Chi, E.; Chaplin, J.A.; Milan, A.; Short, J.M.; DeSantis, G.; Madden, M.; Burk, M.; Robertson, D.E. Nitrilases. US8906663B2, 9 December 2014.

164. Vogel, A.; Schwarze, D.; Greiner-Stoeffele, T. Nitrilases. US8916364B2, 23 December 2014.

165. Doenhoff, M.J.; Cioli, D.; Utzinger, J. Praziquantel: Mechanisms of action, resistance and new derivatives for schistosomiasis. Curr. Opin. Infect. Dis. 2008, 21, 659-667. [CrossRef]

166. da Silva, V.B.R.; Boucherle, B.; El-Methni, J.; Hoffmann, B.; da Silva, A.L.; Fortune, A.; de Lima, M.D.A.; Thomas, A. Could we expect new praziquantel derivatives? A meta pharmacometrics/pharmacoinformatics analysis of all antischistosomal praziquantel derivatives found in the literature. SAR QSAR Environ. Res. 2019, 30, 383-401. [CrossRef]

167. Qian, M. Enzymic Resolution Method for Preparing L-praziquantel. CN102911979A, 6 February 2013.

168. Yao, P.; Wu, Q.; Yuan, J.; Han, C.; Feng, J.; Zhu, D.; Ma, Y. Method for Preparing Beta-Alanine by Enzymatic Hydrolysis of High Concentration of Beta-Amino Propionitrile. CN104195193A, 10 December 2014.

169. Toth, C. Pregabalin: Latest safety evidence and clinical implications for the management of neuropathic pain. Ther. Adv. Drug Saf. 2014, 5, 38-56. [CrossRef] [PubMed]

170. Gerardi, M.C.; Atzeni, F.; Batticciotto, A.; Di Franco, M.; Rizzi, M.; Sarzi-Puttini, P. The safety of pregabalin in the treatment of fibromyalgia. Expert Opin. Drug Saf. 2016, 15, 1541-1548. [CrossRef] [PubMed]

171. Mohile, S.S.; Yeranda, S.G.; Lunge, S.M.; Patel, R.M.; Gugale, S.B.; Thakur, R.M.; Mokal, R.A.; Gangopadhyay, A.K.; Nightingale, P.D. An improved green process for the preparation of pregabalin from isovaleraldehyde via enzymatic enantioselective hydrolysis of alkyl 3-cyano-5-methylhexanoate. WO2014072785A2, 15 May 2014.

172. Mohile, S.S.; Yerande, S.G.; Lunge, S.M.; Patel, R.M.; Gugale, S.B.; Thakur, R.M.; Mokal, R.A.; Gangopadhyay, A.K.; Nightingale, P.D. An Improved Green Process for The Preparation of Pregabalin from Isovaleraldehyde Via Enzymatic Enantioselective Hydrolysis of Alkyl 3-Cyano-5-Methylhexanoate. IN2012MU03228A, 22 July 2016.

173. Xue, Y.; Zheng, Y.; Xu, Z.; Liu, Z.; Wang, Y.; Su, X.; Jia, D. Method for Preparation of 1-Cyano-Cyclohexyl-Acetic Acid Using Nitrilase Engineering Bacteria. CN104212850A, 17 December 2014.

174. Tardif, J.C.; Ford, I.; Tendera, M.; Bourassa, M.G.; Fox, K.; Initiative, I. Efficacy of ivabradine, a new selective I-f inhibitor, compared with atenolol in patients with chronic stable angina. Eur. Heart J. 2005, 26, 2529-2536. [CrossRef] [PubMed]

175. Ide, T.; Ohtani, K.; Higo, T.; Tanaka, M.; Kawasaki, Y.; Tsutsui, H. Ivabradine for the treatment of cardiovascular diseases. Circ. J. 2019, 83, 252-260. [CrossRef] [PubMed]

176. Pedragosa-Moreau, S.; Lefoulon, F. Process for the Enzymatic Synthesis of (7s)-3,4-Dimethoxybicyclo [4.2.0] Octa-1,3,5-Triene-7-Carboxylic Acid and Application in the Synthesis of Ivabradine And Salts Thereof. US20140242644A1, 28 August 2014.

177. Tao, J.; Tang, S.; Li, B.; Liu, G. Method for Preparing Monomethyl (R)-3-Hydroxyglutarate as Rosuvastatin Intermediate by Enzymolysis with Recombinant Nitrilase. CN103361386A, 23 October 2013.

178. Tao, J.; Tang, S.; Li, B.; Liu, G. Method for Preparing Monomethyl (R)-3-Hydroxyglutarate as Rosuvastatin Intermediate by Enzymolysis with Recombinant Nitrilase. WO2014205917A1, 31 December 2014.

179. Chen, L. Continuous Production Method of Hypolipemic Intermediate (R)-3-Hydroxyl Pentanedioic Acid Ethyl Ester. CN104372040A, 25 February 2015. 
180. $\mathrm{Xu}, \mathrm{P} . ; \quad \mathrm{Yu}, \mathrm{H} . ; \quad \mathrm{Han}, \mathrm{S}$; $\mathrm{Li}$, L. Preparation of Fosamprenavir Intermediate (2R,3S)-1,2-Epoxy-3-Tert-Butoxycarbonylamino-4-Phenylbutane. CN104803954A, 29 July 2015.

181. Hu, L.; Xi, C.; Peng, D. Synthetic Method of Clopidogrel and Its Sulfate. CN107523594A, 29 December 2017.

182. Xue, P.; Shuai, H.; Ma, Y.; Zhang, L.; Li, P. Preparation of (S)-2-Chlorophenylglycine Methyl Ester Single Enantiomers by Enzymic Resolution. CN104293875A, 21 January 2015.

183. Zheng, Y.G.; Yin, H.H.; Yu, D.F.; Chen, X.; Tang, X.L.; Zhang, X.J.; Xue, Y.P.; Wang, Y.J.; Liu, Z.Q. Recent advances in biotechnological applications of alcohol dehydrogenases. Appl. Microbiol. Biotechnol. 2017, 101, 987-1001. [CrossRef]

184. Zheng, G.-W.; Ni, Y.; Xu, J.-H. Biocatalytic Processes for the Synthesis of Chiral Alcohols. In Applied Biocatalysis: From Fundamental Science to Industrial Applications; Wiley-VCH Verlag GmbH \& Co. KGaA: Weinheim, Germany, 2016; pp. 219-250.

185. Kratzer, R.; Woodley, J.M.; Nidetzky, B. Rules for biocatalyst and reaction engineering to implement effective, NAD(P)H-dependent, whole cell bioreductions. Biotechnol. Adv. 2015, 33, 1641-1652. [CrossRef] [PubMed]

186. An, J.H.; Nie, Y.; Xu, Y. Structural insights into alcohol dehydrogenases catalyzing asymmetric reductions. Crit. Rev. Biotechnol. 2019, 39, 366-379. [CrossRef]

187. Chen, B.S.; de Souza, F.Z.R. Enzymatic synthesis of enantiopure alcohols: Current state and perspectives. RSC Adv. 2019, 9, 2102-2115. [CrossRef]

188. Uppada, V.; Bhaduri, S.; Noronha, S.B. Cofactor regeneration-an important aspect of biocatalysis. Curr. Sci. 2014, 106, 946-957.

189. Kara, S.; Schrittwieser, J.H.; Hollmann, F. Strategies for Cofactor Regeneration in Biocatalyzed Reductions; Blackwell Science Publ: Oxford, UK, 2014; pp. 209-238.

190. Berenguer-Murcia, A.; Fernandez-Lafuente, R. New Trends in the Recycling of NAD(P)H for the Design of Sustainable Asymmetric Reductions Catalyzed by Dehydrogenases. Curr. Org. Chem. 2010, 14, 1000-1021. [CrossRef]

191. Catapano, A.L. Ezetimibe: A selective inhibitor of cholesterol absorption. Eur. Heart J. Suppl. 2001, 3, E6-E10. [CrossRef]

192. Bruckert, E.; Giral, P.; Tellier, P. Perspectives in cholesterol-lowering therapy-The role of ezetimibe, a new selective inhibitor of intestinal cholesterol absorption. Circulation 2003, 107, 3124-3128. [CrossRef] [PubMed]

193. Kosoglou, T.; Statkevich, P.; Johnson-Levonas, A.O.; Paolini, J.F.; Bergman, A.J.; Alton, K.B. Ezetimibe-A review of its metabolism, pharmacokinetics and drug interactions. Clin. Pharmacokinet 2005, 44, 467-494. [CrossRef] [PubMed]

194. Mundorff, E.; De Vries, E. Ketoreductase Polypeptides for The Stereoselective Production of (4S)-3[(5S)-5(4-Fluorophenyl)-5-hydroxypentanoyl]-4-phenyl-1,3-oxazolidin-2-one. WO2010025085A2, 4 March 2010.

195. Crowe, M.A.; Alvizo, O.; Behrouzian, B.; Bong, Y.K.; Collier, S.J.; Gohel, A.; Mavinahalli, J.; Modukuru, N.; Mundorff, E.; Smith, D.; et al. Genetically Engineered Carbonyl Reductase for Ezetimibe Synthesis. WO2011140219A1, 10 November 2011.

196. Luo, Y.; Ding, S.; Qu, X.; Sun, C. Intermediates Used for Synthesis of Ezetimibe, and Their Preparation Method and Application. CN104860980A, 26 August 2015.

197. Feng, W.; Wang, J. Preparation of Immobilized Ketoreductase or Carbonyl Reductase for Production of Ezetimibe Intermediate with Higher Efficiency and Reduced Wastes. CN105754983A, 13 July 2016.

198. Wu, J.; Chen, S.; He, X.; Yang, L.; Xu, G. Engineering Bacterium and Method for Preparation of Tert-butyl (3r,5s)-6-chloro-3,5-dihydroxy-hexanoate. CN104087546A, 8 October 2014.

199. De Lucchi, O.; Tartaggia, S.; Ferrari, C.; Galvagni, M.; Pontini, M.; Fogal, S.; Motterle, R.; Moreno, R.M.; Comely, A. Process for Preparation of Intermediates for the Synthesis of Statins. WO2014128022A1, 28 August 2014.

200. Hong, H.; Chen, C.; Li, J.; Shen, L.; Guo, L.; Tian, H. Process for Preparation of Chiral Intermediates for Statin Drugs. WO2015168998A1, 12 November 2015.

201. Scott, J.P.; Peters-Golden, M. Antileukotriene agents for the treatment of lung disease. Am. J. Respir. Crit. Care Med. 2013, 188, 538-544. [CrossRef] [PubMed]

202. Matsuse, H.; Kohno, S. Leukotriene receptor antagonists pranlukast and montelukast for treating asthma. Expert Opin. Pharmacother. 2014, 15, 353-363. [CrossRef] [PubMed] 
203. Aslani, A.; Beigi, M. Design, formulation, and physicochemical evaluation of montelukast orally disintegrating tablet. Int. J. Prev. Med. 2016, 7, 8. [CrossRef]

204. Song, J.; Zhang, C.; Long, Z.; Liu, X.; Cai, S. Process for Preparation of Montelukast Sodium Intermediate. CN103936671A, 23 July 2014.

205. Lou, X.; Wang, X. Method for Preparation of Montelukast Sodium Intermediate. CN104326976A, 4 February 2015.

206. Lattanzi, S.; Brigo, F.; Cagnetti, C.; Verrotti, A.; Zaccara, G.; Silvestrini, M. Eslicarbazepine acetate in the treatment of adults with partial-onset epilepsy: An evidence-based review of efficacy, safety and place in therapy. Core Evid. 2018, 13, 21-31. [CrossRef] [PubMed]

207. Gohel, A.; Smith, D.; Wong, B.; Sukumaran, J.; Yeo, W.L.; Collier, S.J.; Novick, S. Biocatalytic Process for Preparing Eslicarbazepine and Analogs Thereof. US20140199735A1, 17 July 2014.

208. Schena, G.; Caplan, M.J. Everything You Always Wanted to Know about (3)-AR * (* But Were Afraid to Ask). Cells 2019, 8, 357. [CrossRef]

209. Morriello, G.J.; Wendt, H.R.; Bansal, A.; Di Salvo, J.; Feighner, S.; He, J.F.; Hurley, A.L.; Hreniuk, D.L.; Salituro, G.M.; Reddy, M.V.; et al. Design of a novel pyrrolidine scaffold utilized in the discovery of potent and selective human beta(3) adrenergic receptor agonists. Bioorg. Med. Chem. Lett. 2011, 21, 1865-1870. [CrossRef]

210. Chung, J.Y.L.; Campos, K.; Cleator, E.; Dunn, R.F.; Gibson, A.; Hoerrner, R.S.; Keen, S.; Lieberman, D.; Liu, Z.; Lynch, J.; et al. Process for Making Beta 3 Agonists and Intermediates. US20140242645A1, 28 August 2014.

211. Xu, F.; Chung, J.Y.L.; Moore, J.C.; Liu, Z.Q.; Yoshikawa, N.; Hoerrner, R.S.; Lee, J.; Royzen, M.; Cleator, E.; Gibson, A.G.; et al. Asymmetric synthesis of cis-2,5-disubstituted pyrrolidine, the core scaffold of beta (3)-AR agonists. Org. Lett. 2013, 15, 1342-1345. [CrossRef]

212. Krug, A.W.; Ziegler, C.G.; Bornstein, S.R. DHEA and DHEA-S, and their functions in the brain and adrenal medulla. In Neuroactive Steroids in Brain Function, Behavior and Neuropsychiatric Disorders: Novel Strategies for Research and Treatment; Ritsner, M.S., Weizman, A., Eds.; Springer: Dordrecht, The Netherlands, 2008; pp. 227-239.

213. Fryszkowska, A.; Quirmbach, M.S.; Gorantla, S.S.C.; Alieti, S.R.; Poreddy, S.R.; Dinne, N.K.R.; Timmanna, U.; Dahanukar, V. Processes for the Preparation of Dehydroepiandrosterone and Its Intermediates. WO2014188353A2, 27 November 2014.

214. Xie, X.; Huang, X.; Zhang, J.; Zhang, R. Biological Preparation Method of Dehydroepiandrosterone. CN105695551A, 22 June 2016.

215. Tao, J.; Le, Y. A Biological Preparation Method of (1R, 2S)-N-pyrrolidinyl Norephedrine. CN104805148A, 29 July 2015.

216. Yasuda, N.; Tan, L. Efavirenz, a non-nucleoside reverse transcriptase inhibitor (NNRTI), and a previous structurally related development candidate. In Art of Process Chemistry; Yasuda, N., Ed.; Wiley-VCH Verlag GmbH \& Co. KGaA: Weinheim, Germany, 2011; pp. 1-43.

217. Costa, C.C.P.; Boechat, N.; da Silva, F.C.; Rosario, S.L.; Bezerra, T.C.; Bastos, M.M. The Efavirenz: Structure-activity relantionship and synthesis methods. Rev. Virtual Quim. 2015, 7, 1347-1370. [CrossRef]

218. Jin, Y.; Yao, Y.; Han, G. Enzymatic Method for Preparation of (S)-3-Piperidinol and Its Derivatives with High Chiral Purity from N-3-Piperidone and Its Derivatives. CN103898178A, 2 July 2014.

219. Wu, Z.; Ren, Z.; Liu, Y. Preparation of Thienyl Chiral Alcohol Compound as Intermediate for Synthesis of Duloxetine by Biocatalysis in the Presence of Carbonyl Reductase. CN104830924A, 12 August 2015.

220. Carter, N.J.; McCormack, P.L. Duloxetine. CNS Drugs 2009, 23, 523-541. [CrossRef] [PubMed]

221. Detke, M.J.; Lu, Y.L.; Goldstein, D.J.; Hayes, J.R.; Demitrack, M.A. Duloxetine, 60 mg once daily, for major depressive disorder: A randomized double-blind placebo-controlled trial. J. Clin. Psychiatry 2002, 63, 308-315. [CrossRef] [PubMed]

222. De Donatis, D.; Florio, V.; Forceili, S.; Saria, A.; Mercolini, L.; Serretti, A.; Conca, A. Duloxetine plasma level and antidepressant response. Prog. Neuro-Psychopharmacol. Biol. Psychiatry 2019, 92, 127-132. [CrossRef] [PubMed]

223. Savile, C.; Gruber, J.M.; Mundorff, E.; Huisman, G.W.; Collier, S.J. Ketoreductase Polypeptides for the Stereospecific Production of (S)-3-aryl-3-hydroxypropanamines from 3-aryl-3-ketopropanamines. WO2010025238A2, 4 March 2010.

224. Nie, Y.; Xu, Y.; Wang, Y. Method for Asymmetric Synthesis of Duloxetine Intermediate with Carbonyl Reductase. CN105803013A, 27 July 2016. 
225. Zhang, Z.J.; Pan, J.; Ma, B.D.; Xu, J.H. Efficient biocatalytic synthesis of chiral chemicals. In Bioreactor Engineering Research and Industrial Applications; Springer Science and Business Media Deutschland GmbH: Berlin, Germany, 2016; Volume 155, pp. 55-106.

226. Xie, X.; Huang, X.; Zhang, J.; Zhang, R. Method for Preparing Ethyl (R)-2-hydroxy-4-phenylbutyrate. CN105732373A, 6 July 2016.

227. Lin, J.; Chestakova, A.; Gu, W.; Iding, H.; Li, J.; Linghu, X.; Meier, P.; Sha, C.; Stults, J.; Wang, Y.; et al. Process for the Manufacturing of a Pyrazolylaminopyrimidine Derivative. WO2015154674A1, 15 October 2015.

228. Blake, J.F.; Burkard, M.; Chan, J.; Chen, H.F.; Chou, K.J.; Diaz, D.; Dudley, D.A.; Gaudino, J.J.; Gould, S.E.; Grina, J.; et al. Discovery of (S)-1-(1-(4-Chloro-3-fluorophenyl)-2-hydroxyethyl)-4-(2-((1-methyl-1H-py razol-5-yl)amino)pyrimidin-4-yl)pyridin-2(1H)-one (GDC-0994), an extracellular signal-regulated kinase 1/2 (ERK1/2) inhibitor in early clinical development. J. Med. Chem. 2016, 59, 5650-5660. [CrossRef] [PubMed]

229. Zhang, M.K.; Peyear, T.; Patmanidis, I.; Greathouse, D.V.; Marrink, S.J.; Andersen, O.S.; Ingolfsson, H.I. Fluorinated Alcohols' Effects on Lipid Bilayer Properties. Biophys. J. 2018, 115, 679-689. [CrossRef]

230. Tao, J.; Zhang, W.; Liang, X. Preparation of (S)-1,1,1-Trifluoroisopropanol by Enzymic Resolution. CN104894169A, 9 Septenber 2015.

231. Bong, Y.K.; Vogel, M.; Collier, S.J.; Mitchell, V.; Mavinahalli, J. Polypeptides for a Ketoreductase-Mediated Stereoselective Route to Alpha Chloroalcohols. US8796002B2, 5 August 2014.

232. Mangas-Sanchez, J.; France, S.P.; Montgomery, S.L.; Aleku, G.A.; Man, H.; Sharma, M.; Ramsden, J.I.; Grogan, G.; Turner, N.J. Imine reductases (IREDs). Curr. Opin. Chem. Biol. 2017, 37, 19-25. [CrossRef]

233. Grogan, G.; Turner, N.J. InspIRED by nature: NADPH-dependent imine reductases (IREDs) as catalysts for the preparation of chiral amines. Chem. Eur. J. 2016, 22, 1900-1907. [CrossRef]

234. Maugeri, Z.; Rother, D. Application of Imine Reductases (IREDs) in Micro-Aqueous Reaction Systems. Adv. Synth. Catal. 2016, 358, 2745-2750. [CrossRef]

235. Maugeri, Z.; Rother, D. Reductive amination of ketones catalyzed by whole cell biocatalysts containing imine reductases (IREDs). J. Biotechnol. 2017, 258, 167-170. [CrossRef]

236. Lenz, M.; Borlinghaus, N.; Weinmann, L.; Nestl, B.M. Recent advances in imine reductase-catalyzed reactions. World, J. Microbiol. Biotechnol. 2017, 33, 10. [CrossRef] [PubMed]

237. Cosgrove, S.C.; Brzezniak, A.; France, S.P.; Ramsden, J.I.; Mangas-Sanchez, J.; Montgomery, S.L.; Heath, R.S.; Turner, N.J. Imine reductases, reductive aminases, and amine oxidases for the synthesis of chiral amines: Discovery, characterization, and synthetic applications. In Enzymes in Synthetic Biology; Scrutton, N., Ed.; Elsevier Academic Press Inc.: San Diego, CA, USA, 2018; Volume 608, pp. 131-149.

238. Gamenara, D.; Domínguez de María, P. Enantioselective imine reduction catalyzed by imine reductases and artificial metalloenzymes. Org. Biomol. Chem. 2014, 12, 2989-2992. [CrossRef] [PubMed]

239. Velikogne, S.; Resch, V.; Dertnig, C.; Schrittwieser, J.H.; Kroutil, W. Sequence-based in-silico discovery, characterisation, and biocatalytic application of a set of imine reductases. ChemCatChem 2018, 10, 3236-3246. [CrossRef] [PubMed]

240. Patil, M.D.; Grogan, G.; Bommarius, A.; Yun, H. Oxidoreductase-catalyzed synthesis of chiral amines. ACS Catal. 2018, 8, 10985-11015. [CrossRef]

241. Agard, N.J.; Alvizo, O.; Mayo, M.A.; Minor, S.N.; Riggins, J.N.; Moore, J.C. Variants of the Opine Dehydrogenase of Arthrobacter C1 for Use in the Reductive Amination of Ketones and Amines. US20150132807A1, 14 May 2015.

242. Chen, H.; Moore, J.; Collier, S.J.; Smith, D.; Nazor, J.; Hughes, G.; Janey, J.; Huisman, G.; Novick, S.; Agard, N.; et al. Engineered Imine Reductases and Methods for the Reductive Amination of Ketone and Amine Compounds. WO2013170050A1, 14 November 2013.

243. Debarge, S.; Erdman, D.T.; O’Neill, P.M.; Kumar, R.; Karmilowicz, M.J. Process and Intermediates for the Preparation of Pregabalin. WO2014155291A1, 2 October 2014.

244. Turner, N.J. Enantioselective oxidation of C-O and C-N bonds using oxidases. Chem. Rev. 2011, 111, $4073-4087$. [CrossRef] [PubMed]

245. Hollmann, F.; Arends, I.; Buehler, K.; Schallmey, A.; Buhler, B. Enzyme-mediated oxidations for the chemist. Green Chem. 2011, 13, 226-265. [CrossRef]

246. Romano, D.; Villa, R.; Molinari, F. Preparative biotransformations: Oxidation of alcohols. ChemCatChem 2012, 4, 739-749. [CrossRef]

247. Wu, S.K.; Liu, J.; Li, Z. Organic synthesis via oxidative cascade biocatalysis. Synlett 2016, 27, $2644-2658$. 
248. Dong, J.J.; Fernandez-Fueyo, E.; Hollmann, F.; Paul, C.E.; Pesic, M.; Schmidt, S.; Wang, Y.H.; Younes, S.; Zhang, W.Y. Biocatalytic oxidation reactions: A chemist's perspective. Angew. Chem.Int. Ed. 2018, 57, 9238-9261. [CrossRef]

249. Liu, J.; Wu, S.K.; Li, Z. Recent advances in enzymatic oxidation of alcohols. Curr. Opin. Chem. Biol. 2018, 43, 77-86. [CrossRef]

250. Schulz, S.; Girhard, M.; Urlacher, V.B. Biocatalysis: Key to Selective Oxidations. ChemCatChem 2012, 4, $1889-1895$. [CrossRef]

251. Gamenara, D.; Seoane, G.; Méndez, P.S.; Domínguez de de María, P. Redox Biocatalysis: Fundamentals and Applications; John Wiley \& Sons, Inc.: Hoboken, NJ, USA, 2012.

252. Wang, Y.H.; Lan, D.M.; Durrani, R.; Hollmann, F. Peroxygenases en route to becoming dream catalysts. What are the opportunities and challenges? Curr. Opin. Chem. Biol. 2017, 37, 1-9. [CrossRef] [PubMed]

253. Van Rantwijk, F.; Sheldon, R.A. Selective oxygen transfer catalysed by heme peroxidases: Synthetic and mechanistic aspects. Curr. Opin. Biotechnol. 2000, 11, 554-564. [CrossRef]

254. Hofrichter, M.; Ullrich, R. Oxidations catalyzed by fungal peroxygenases. Curr. Opin. Chem. Biol. 2014, 19, 116-125. [CrossRef] [PubMed]

255. Urlacher, V.B.; Girhard, M. Cytochrome P450 monooxygenases: An update on perspectives for synthetic application. Trends Biotechnol. 2012, 30, 26-36. [CrossRef] [PubMed]

256. Fasan, R. Tuning P450 enzymes as oxidation catalysts. ACS Catal. 2012, 2, 647-666. [CrossRef]

257. Bucko, M.; Gemeiner, P.; Schenkmayerova, A.; Krajcovic, T.; Rudroff, F.; Mihovilovic, M.D. Baeyer-Villiger oxidations: Biotechnological approach. Appl. Microbiol. Biotechnol. 2016, 100, 6585-6599. [CrossRef] [PubMed]

258. Bondani, P.B.; Fraaije, M.W.; de Gonzalo, G. Recent developments in flavin-based catalysis: Enzymatic sulfoxidations. In Green Biocatalysis; Patel, R.N., Ed.; John Wiley \& Sons, Inc.: Hoboken, NJ, USA, 2016; pp. 149-164.

259. Urlacher, V.B.; Girhard, M. Cytochrome P450 monooxygenases in biotechnology and synthetic biology. Trends Biotechnol. 2019, 37, 882-897. [CrossRef]

260. Strand, D.S.; Kim, D.; Peura, D.A. 25 Years of proton pump inhibitors: A comprehensive review. Gut Liver 2017, 11, 27-37. [CrossRef]

261. Bong, Y.K.; Clay, M.D.; Collier, S.J.; Mijts, B.; Vogel, M.; Zhang, X.; Zhu, J.; Nazor, J.; Smith, D.; Song, S. Synthesis of Prazole Compounds. US8895271B2, 25 November 2014.

262. Kayser, M.M.; Clouthier, C.M. New bioorganic reagents: Evolved cyclohexanone monooxygenases-Why is it more selective? J. Org. Chem. 2006, 71, 8424-8430. [CrossRef]

263. Ang, E.L.; Clay, M.D.; Behrouzian, B.; Eberhard, E.; Collier, S.J.; Fu Fan, J.; Smith, D.; Song, S.; Alvizo, O.; Widegren, M.; et al. Chemoenzymic Synthesis of Armodafinil Using Genetically Modified Acinetobacter Cyclohexanone Monooxygenase. WO2012078800A2, 14 June 2012.

264. Phillips, J.B.; Simmons, R.G.; Arnold, R.D. A single dose of armodafinil significantly promotes vigilance $11 \mathrm{~h}$ post-dose. Mil. Med. 2011, 176, 833-839. [CrossRef] [PubMed]

265. Garnock-Jones, K.P.; Dhillon, S.; Scott, L.J. Armodafinil. CNS Drugs 2009, 23, 793-803. [CrossRef] [PubMed]

266. Kino, K.; Furuya, T. Production of (-)-rotundone from $\alpha$-guaiene catalyzed by cytochrome P450 enzymes. EP3255151A2, 13 December 2017.

267. Wood, C.; Siebert, T.E.; Parker, M.; Capone, D.L.; Elsey, G.M.; Pollnitz, A.P.; Eggers, M.; Meier, M.; Vossing, T.; Widder, S.; et al. From wine to pepper: Rotundone, an obscure sesquiterpene, is a potent spicy aroma compound. J. Agric. Food Chem. 2008, 56, 3738-3744. [CrossRef] [PubMed]

268. Pecyna, M.J.; Schnorr, K.M.; Ullrich, R.; Scheibner, K.; Kluge, M.G.; Hofrichter, M. Fungal Peroxygenases and Use for Regioselective Oxidation of N-Heterocycles. WO2008119780A2, 9 October 2008.

269. Steffen-Munsberg, F.; Vickers, C.; Kohls, H.; Land, H.; Mallin, H.; Nobili, A.; Skalden, L.; van den Bergh, T.; Joosten, H.J.; Berglund, P.; et al. Bioinformatic analysis of a PLP-dependent enzyme superfamily suitable for biocatalytic applications. Biotechnol. Adv. 2015, 33, 566-604. [CrossRef] [PubMed]

270. Patil, M.D.; Grogan, G.; Bommarius, A.; Yun, H. Recent Advances in omega-transaminase-mediated biocatalysis for the enantioselective synthesis of chiral amines. Catalysts 2018, 8, 254. [CrossRef]

271. Bornscheuer, U.; Hanlon, S.P.; Iding, H.; Pavlidis, I.; Spurr, P.; Steffen Weiss, M.; Wirz, B. Variants of a Bacterial Transaminase with Increased Catalytic Activity for the Synthesis of Chiral Amines. WO2016166120A1, 20 October 2016. 
272. Dhawan, I.K.; Miller, G.; Zhang, X. Transaminase Polypeptides with Improved Thermostability and Enantioselectivity for the Synthesis of Chiral Amines. WO2010081053A2, 15 July 2010.

273. Hughes, G.; Devine, P.N.; Fleitz, F.J.; Grau, B.T.; Limanto, J.; Savile, C.; Mundorff, E. Engineering of Arthrobacter Transaminase Variants, and Use for Biocatalytic Asymmetric Preparation of Chiral Amines from Prochiral Ketones. WO2011005477A1, 13 January 2011.

274. Savile, C.; Mundorff, E.; Moore, J.C.; Devine, P.N.; Janey, J.M. Construction of Arthrobacter KNK168 Transaminase Variants for Biocatalytic Manufacture of Sitagliptin. WO2010099501A2, 2 September 2010.

275. Schuermann, M.; Peeters, W.P.H.; Smeets, N.H.J.; Schwab, H.; Steiner, K.; Lypetska, K.M.; Strohmeier, G. Stereoselective Transamination Catalyzed by Novel R-Selective Transaminases. WO2012007548A1, 19 January 2012.

276. Hong, H.; Gao, F.; Li, Y.; Zhang, Y.; Li, S. Sequence of Transaminase Mutants and Its Use for Synthesizing R configuration Chiral Amine. CN104328094A, 4 February 2015.

277. Tao, R.; Zhu, F.; Shen, Q.; Sun, L.; Shen, Z.; Jiang, Y.; Yang, C. Transaminase for Producing Antiepileptic Drug Levetiracetam Intermediate L-2-aminobutyric acid. CN105441403A, 30 March 2016.

278. Wang, H.; Xie, Y.; Wang, J.; Fan, H.; Wei, D. S type $\omega$-transaminase ATA-W12 and Gene and Application Thereof. CN106520719A, 22 March 2017.

279. Shin, J.-S.; Park, E.-S.; Han, S.-W. Omega-transaminase Bacterial Mutants with Activity Improvements Toward Ketones and Methods for Producing Optically Pure Amines. US20160298092A1, 13 October 2016.

280. Shin, J.S.; Park, E.S. Production of Optically Active Amines by Using Omega Transaminase Derived from Ochrobactrum Anthropi and Devoid of Substrate and Product Inhibition. KR2014123166A, 22 October 2014.

281. Truppo, M.D.; Janey, J.M.; Hughes, G. Immobilization of Transaminases on Resin Carriers for Use in the Manufacture of Sitagliptin. WO2012177527A1, 27 December 2012.

282. Huang, Q.; Zhang, X.; Xiang, S. One Kind of Immobilization Method of Transaminase. CN104774830A, 15 July 2015.

283. Truppo, M.D.; Journet, M.; Strotman, H.; McMullen, J.P.; Grosser, S.T. Immobilized Transaminases for the Preparation of Sitagliptin by Stereospecific Amination of Prositagliptin Ketone. WO2014133928A1, 4 September 2014.

284. Aroda, V.R.; Henry, R.R.; Han, J.; Huang, W.Y.; DeYoung, M.B.; Darsow, T.; Hoogwerf, B.J. Efficacy of GLP-1 Receptor Agonists and DPP-4 Inhibitors: Meta-Analysis and Systematic Review. Clin. Ther. 2012, 34, 1247-1258. [CrossRef]

285. Luo, Y.; Ding, S.; Qu, X.; Guo, F. Immobilized Transaminase and Its Application in Synthesizing Sitagliptin Intermediate. CN104805069A, 29 July 2015.

286. Luo, Y.; Ding, S.; Qu, X. Immobilized Transaminase and Its Application in Synthesis of Sitagliptin Intermediate. CN105219745A, 6 January 2016.

287. Luo, Y.; Ding, S.; Qu, X. Mycobacterium Vanbaalenii Transaminase and Its Application in Preparing Sitagliptin Intermediate. CN105018440A, 4 November 2015.

288. Savile, C.K.; Janey, J.M.; Mundorff, E.C.; Moore, J.C.; Tam, S.; Jarvis, W.R.; Colbeck, J.C.; Krebber, A.; Fleitz, F.J.; Brands, J.; et al. Biocatalytic asymmetric synthesis of chiral amines from ketones applied to sitagliptin manufacture. Science 2010, 329, 305-309. [CrossRef]

289. Robins, K.; Bornscheuer, U.; Hoehne, M. Process for Preparation of Optically Active N-protected 3-Aminopyrrolidine or Optically Active N-protected 3-aminopiperidine and the Corresponding Ketones by Optical Resolution of the Racemic Amine Mixtures Employing a Bacterial Omega-Transaminase. WO2008028654A1, 13 March 2008.

290. Robins, K.; Bornscheuer, U.; Hoehne, M. Preparation of Optically Active Chiral Amines Using a Stereoselective transaminase. EP1818411A1, 15 August 2007.

291. Lin, Y.; Hong, H.; Yan, J.; Wang, Z. Preparation of 3-Aminopyrrolidine Compounds and Their Application. CN104262225A, 7 January 2015.

292. Stass, H.; Dalhoff, A.; Kubitza, D.; Schuhly, U. Pharmacokinetics, safety, and tolerability of ascending single doses of moxifloxacin, a new 8-methoxy quinolone, administered to healthy subjects. Antimicrob. Agents Chemother. 1998, 42, 2060-2065. [CrossRef]

293. Limanto, J.; Beutner, G.; Grau, B.; Janey, J.; Klapars, A.; Ashley, E.R.; Strotman, H.R.; Truppo, M.D.; Hughes, G.; Cabirol, F.; et al. Biocatalysts and Methods for the Synthesis of (1R,2R)-2-(3,4-dimethoxyphenethoxy)cyclohexanamine. US8932836B2, 13 January 2015. 
294. Kossaify, A. Vernakalant in atrial fibrillation: A relatively new weapon in the armamentarium against an old enemy. Drug Target. Insights 2019, 13, 7. [CrossRef]

295. Hall, A.J.M.; Mitchell, A.R.J. Introducing Vernakalant into clinical practice. Arrhythm. Electrophysiol. Rev. 2019, 8, 70-74. [CrossRef]

296. Cabirol, F.; Gohel, A.; Oh, S.H.; Smith, D.; Wong, B.; LaLonde, J. Biocatalysts and Methods for the Synthesis of (S)-3-(1-aminoethyl)-phenol. WO2011159910A2, 22 December 2011.

297. Cabirol, F.; Chen, H.; Gohel, A.; Salim, P.; Smith, D.; Janey, J.; Kosjek, B.; Tang, W.L.; Hsieh, H.; Pham, S. Biocatalysts and Methods for the Synthesis of Substituted Lactams. US9109209B2, 18 August 2015.

298. Limanto, J.; Beutner, G.L.; Yin, J.; Klapars, A.; Ashley, E.R.; Strotman, H.R.; Truppo, M.D.; Chung, C.K.; Hughes, G.; Liu, Z.; et al. Process for Preparing Aminocyclohexyl Ether Compounds. US9006460B2, 14 April 2015.

299. Austad, B.; Bahadoor, A.; Belani, J.D.; Janardanannair, S.; Johannes, C.W.; Keaney, G.F.; Lo, C.K.; Wallerstein, S.L. Enzymatic Transamination of Cyclopamine Analogs. WO2011017551A1, 10 February 2011.

300. Crowe, M.; Foulkes, M.; Francese, G.; Grimler, D.; Kuesters, E.; Laumen, K.; Li, Y.; Lin, C.; Nazor, J.; Ruch, T; et al. Chemical Process for Preparing Spiroindolones and Intermediates Thereof. WO2013139987A1, 26 September 2013.

301. Sieber, V.; Grammann, K.; Ruehmann, B.; Haas, T.; Pfeffer, J.; Doderer, K.; Rollmann, C.; Skerra, A.; Rausch, C.; Lerchner, A. Enzymic transamination of multicyclic dianhydro diuloses. WO2010089171A2, 12 August 2010.

302. Tao, J.; Liang, X.; Le, Y. Method for Preparation of (S)-2-amino-1-butanol by Biological Process. CN105177071A, 23 December 2015.

303. Qu, D.; Huang, Y. Synthesis Method of Efinaconazole Intermediate. CN105039450A, 11 November 2015.

304. Tatsumi, Y.; Nagashima, M.; Shibanushi, T.; Iwata, A.; Kangawa, Y.; Inui, F.; Siu, W.J.J.; Pillai, R.; Nishiyama, Y. Mechanism of action of efinaconazole, a novel triazole antifungal agent. Antimicrob. Agents Chemother. 2013, 57, 2405-2409. [CrossRef] [PubMed]

305. Gupta, A.K.; Cernea, M. How effective is efinaconazole in the management of onychomycosis? Expert Opin. Pharmacother. 2016, 17, 611-618. [CrossRef] [PubMed]

306. Occhipinti, A.; Berlicki, L.; Giberti, S.; Dziedziola, G.; Kafarski, P.; Forlani, G. Effectiveness and mode of action of phosphonate inhibitors of plant glutamine synthetase. Pest Manag. Sci. 2010, 66, 51-58. [CrossRef] [PubMed]

307. Yang, L.; Zhou, H.; Meng, L.; Liu, S.; Wei, Y.; Gu, S.; Yuan, X.; Fang, H.; Liu, Y.; Xu, G.; et al. A Production Method of L-glufosinate ammonium. CN105603015A, 25 May 2016.

308. Green, B.M.; Gradley, M.L. Two-step Enzymic Synthesis of L-glufosinate from Racemic Mixture. US20170253897A1, 7 September 2017.

309. Bulger, P.G.; Kosjek, B.; Rivera, N. Biocatalytic Transamination Process for the Enantioselective Syntheses of 3-Arylpiperidine, Key Intermediate in the Prepn. of Poly (adp-ribose) Polymerase Inhibitors. WO2014088984A1, 12 June 2014.

310. Kim, M.H.; Han, G.S. Method for Producing D-alanine Using Fusion Enzyme. KR2017132446A, 4 December 2017.

311. Yun, D.H.; Lee, H.S. Enzymatic Production Method of Optically Active Beta-Amino Acids Including Intermediate for the Synthesis of Sitagliptin. KR101565439B1, 18 November 2015.

312. Shin, J.S.; Park, E.S.; Dong, J.Y. Simultaneous Production of High-Purity Optically Active Alkylamine and Aryl Alkylamine Using Transaminase. KR2014108422A, 11 September 2014.

313. Shin, J.-S.; Park, E.-S.; Malik, M.S. Method for Preparing Optically Active Amine Compound Using Deracemization. WO2014092496A1, 19 June 2014.

314. Huisman, G.W.; Agard, N.J.; Mijts, B.; Vroom, J.; Zhang, X. Robust Variants of a Phenylalanine Ammonia Lyase with Increased Catalytic Activity for Therapeutic Use. WO2014172541A2, 23 October 2014.

315. Wu, B.; Szymanski, W.; Crismaru, C.G.; Feringa, B.L.; Janssen, D.B. C-N Lyases Catalyzing Addition of Ammonia, Amines, and Amides to $\mathrm{C}=\mathrm{C}$ and $\mathrm{C}=\mathrm{O}$ Bonds. In Enzyme Catalysis in Organic Synthesis, 3rd ed.; Drauz, K., Groeger, H., May, O., Eds.; Jonh Wiley and Sons, Inc.: Hoboken, NJ, USA, 2012; pp. 749-778.

316. Huisman, G.W.; Agard, N.J.; Elgart, D.; Zhang, X. Tyrosine: Ammonia Lyase Variants Stable at Acid pH and Resistant to Proteolysis and Their Use in Treatment of Metabolic Disease. WO2015161019A1, 22 October 2015.

317. Weiner, D.; Varvak, A.; Richardson, T.; Podar, M.; Burke, E.; Healey, S. Lyase Enzymes, Nucleic Acids Encoding Them and Methods for Their Production and Commercial Use. WO2006099207A2, 21 September 2006. 
318. Bruehlmann, F.; Fourage, L.; Wahler, D. Engineering of Modified Guava 13-hydroperoxide Lyase Variants with Improved Enzymic Activity for Use in the Production of Aldehydes and Alcohols. WO2009001304A1, 31 December 2008.

319. Asano, Y.; Dadashipour Lakmehsar, M.; Ishida, Y. Purification and characterization of novel (R)-hydroxynitrile lyase. WO2015133462A1, 11 September 2015.

320. Eggert, T.; Andexer, J. An (R)-hydroxynitrile Lyase from a Non-Cyanogenic Member of the Brassicaceae for Use in Stereoselective Addition. WO2008067807A2, 12 June 2008.

321. Glieder, A. R-Hydroxynitrile Lyase Random Variants and Their Use for Preparing Optically Pure, Sterically Hindered Cyanohydrins. WO2008071695A1, 19 June 2008.

322. Xiao, Y.; Yang, W.; Chen, M.; Gong, B.; Yan, Y.; Tan, C. Levodopa Crystal Powder and Preparation Method Thereof. CN106117072A, 16 November 2016.

323. De Deurwaerdère, P.; Di Giovanni, G.; Millan, M.J. Expanding the repertoire of L-DOPA's actions: A comprehensive review of its functional neurochemistry. Prog. Neurobiol. 2017, 151, 57-100. [CrossRef] [PubMed]

324. Jenner, P. Molecular mechanisms of L-DOPA-induced dyskinesia. Nat. Rev. Neurosci. 2008, 9, 665-677. [CrossRef] [PubMed]

325. Cools, R. Dopaminergic modulation of cognitive function-implications for L-DOPA treatment in Parkinson's disease. Neurosci. Biobehav. Rev. 2006, 30,1-23. [CrossRef] [PubMed]

326. Rother, D.; Pohl, M.; Sehl, T.; Baraibar, A.G. Enzymic Twostep Process for the Production of Cathine. DE102013009631A1, 11 December 2014.

327. Rother, D.; Pohl, M.; Sehl, T.; Baraibar, A.G. Process for Producing Cathine. WO2014198247A1, 18 December 2014.

328. Hauner, H.; Hastreiter, L.; Werdier, D.; Chen-Stute, A.; Scholze, J.; Bluher, M. Efficacy and safety of cathine (nor-pseudoephedrine) in the treatment of obesity: A randomized dose-finding study. Obes. Facts 2017, 10, 407-419. [CrossRef] [PubMed]

329. Alsufyani, H.A.; Docherty, J.R. Cathine and MHA act as indirect sympathomimetics to produce cardiovascular actions. Br. J. Pharmacol. 2019, 176, 3036.

330. Clapés, P. Enzymatic C-C Bond Formation. In Organic Synthesis Using Biocatalysis; Goswami, A., Stewart, J.D., Eds.; Academic Press: Cambridge, MA, USA, 2016; pp. 285-337.

331. Brovetto, M.; Gamenara, D.; Mendez, P.S.; Seoane, G.A. C-C Bond-forming lyases in organic synthesis. Chem. Rev. 2011, 111, 4346-4403. [CrossRef]

332. Sehl, T.; Hailes, H.C.; Ward, J.M.; Menyes, U.; Pohl, M.; Rother, D. Efficient 2-step biocatalytic strategies for the synthesis of all nor(pseudo) ephedrine isomers. Green Chem. 2014, 16, 3341-3348. [CrossRef]

333. Sehl, T.; Hailes, H.C.; Ward, J.M.; Wardenga, R.; von Lieres, E.; Offermann, H.; Westphal, R.; Pohl, M.; Rother, D. Two steps in one pot: Enzyme cascade for the synthesis of nor(pseudo)ephedrine from inexpensive starting materials. Angew. Chem. Int. Ed. 2013, 52, 6772-6775. [CrossRef] [PubMed]

334. Erdmann, V.; Sehl, T.; Frindi-Wosch, I.; Simon, R.C.; Kroutil, W.; Rother, D. Methoxamine Synthesis in a Biocatalytic 1-Pot 2-Step Cascade Approach. ACS Catal. 2019, 9, 7380-7388. [CrossRef]

335. Mrak, P.; Zohar, T.; Oslaj, M.; Kopitar, G. Enzymatic Synthesis of Statins and Intermediates Thereof. WO2012095244A2, 19 July 2012.

336. Casar, Z.; Mesar, T.; Kopitar, G.; Mrak, P.; Oslaj, M. Synthesis of Statins from (4R,6S)-6-(dialkoxymethyl) tetrahydro-2H-pyran-2,4-diol. WO2008119810A2, 9 October 2008.

337. Cluzeau, J.; Casar, Z.; Mrak, P.; Oslaj, M.; Kopitar, G. Process for the Production of ((2S,4R)-4,6-dihydroxytetrahydro-2H-pyran-2-yl)methyl Carboxylates and Its Further use to Synthesisze Statins. WO2009092702A2, 20 July 2009.

338. Bauer, D.W.; Hu, S.; O’Neill, P.M.; Watson, T.J.N. Process for Preparing Chiral Compounds Using 2-Deoxyribose-5-phosphate aldolase. WO2009019561A2, 12 February 2009.

339. Matsumoto, K.; Kazuno, Y.; Higashimura, N.; Ohshima, T.; Sakuraba, H. Enzymic Preparation of Chiral Hydroxyaldehydes. WO2005098012A1, 20 October 2005.

340. Zhu, G.; Qi, X.; Li, B.; Wang, C.; Zhang, H.; Liu, Y.; Pan, X. Chemoenzymic Synthesis of Atorvastatin Calcium Side Chain with High Chiral Purity. CN103060396A, 12 September 2013.

341. Oh, D.G.; Lee, S.H.; Hong, S.H. Method for Producing Tagatose from Fructose and Enzyme Composition Therefor. KR1480422B1, 5 February 2015. 
342. Oh, D.K.; Hong, S.H.; Lee, S.H. Method for Producing Tagatose from Fructose and Enzyme Composition Therefor. WO2015016544A1, 5 February 2015.

343. Xu, G.; Zeng, H.; Zhao, S.; Chen, M. Method for Producing L-alpha-aminobutyric acid with High Optical Activity by Biological Catalysis. CN104774881A, 15 July 2015.

344. Kroutil, W.; Busto, E.; Simon, R. Method for Producing p-vinylphenols. AT516155A4, 15 March 2016.

345. Kroutil, W.; Busto, E.; Simon, R. Method for Producing p-vinylphenols. WO2016141397A1, 15 September 2016.

(C) 2019 by the authors. Licensee MDPI, Basel, Switzerland. This article is an open access article distributed under the terms and conditions of the Creative Commons Attribution (CC BY) license (http://creativecommons.org/licenses/by/4.0/). 